STATE OF ILLINOIS

DEPARTMENT OF REGISTRATION AND EDUCATION

DIVISION OF THE

NATURAL HISTORY SURVEY

STEPHEN A. FORBES, Chief

Vol. XVII. BULLETIN Article XII.

\title{
The Bottom Fauna of the Middle Illinois River, 1913-1925
}

Its Distribution, Abundance, Valuation, and Index Value in the Study of Stream Pollution

BY

R. E. RICHARDSON

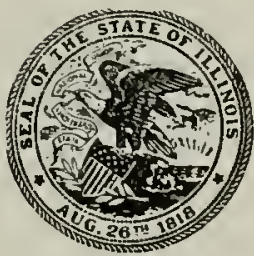

PRINTED BY AUTHORITY OF THE STATE OF ILLINOIS

\section{URBANA, ILLINOIS}

December, 1928 
STATE OF ILLINOIS

DEPARTMENT OF REGISTRATION AND EDUCATION

A. M. Shelton, Director

BOARD OF

NATURAL RESOURCES AND CONSERVATION

A. M. Shelton, Chairman

William Trelease, Biology

Henry C. Cowles, forestry

Edson S. BAstin, Geology

William A. Nores, Chemistry
JонN W. Alrond, Engineering

Charles M. Thompson, Representing the President of the University of Illinois

THE NATURAL HISTORY SURVEY DIVISION

Stepinen A. Forbes, Chief

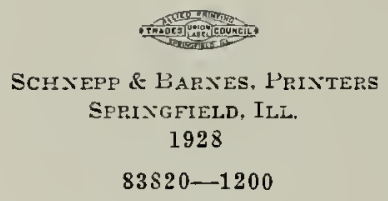




\section{FOREWORD}

The present article is the twenty-third of a series of bulletins strictly devoted to Illinois River biology, containing ?10s pages and 15.5 plates, published during the past it years by the Illinois State Laboratory of Natural History and its successor, the State Natural History Surver, as a product of operations carried on from 18 it to 192 .

It was the guiding purpose of these studies to make a comprehensive survey of the plants and animals of the stream and its tributary waters. and to analyze their interactions with each other and with their plysical environment during all seasons of the year and under the varions conditions of successive years, especial attention being paid to food relations and to effects produced upon the biological system of the stream by the periodical overflow and gradual recession of its waters-a phenomenon of which the Illinois offered a notable example owing to its generally sluggish current and the umusual extent of its bottomlands. During the early years of this period especial attention was given to the fishes of the stream and its connected waters, but not to the exclusion of the other inhabitants.

In $189+$ these preliminary studies, which were a part only of a general progran covering the entire state, were concentrated and adequately: provicled for by the establishment of a biological station, with a completely portable equipment, at Havana on the Illinois River. at which place continuous investigation was carried on from 1s95 to 1900. supplenented by a summer's operation with Meredosia, ti miles below, as its center. and by a year's work on the upper river for which the station equipment was moved to Ottawa in 1!)(1). The Illinois River operations were thereafter limited for a time to occasional visits while the other streams of the state were being explored and a report on the fishes of Illinois was being prepared and published, but continuous operations on Illinois River biology were resumed in 190 !) and were carrice on with only occasional interruptions until 1925.

The time necessary to accomplish the purposes in view was greatly prolonged by the repeated occurrence of revolutionary changes in condition, affecting the biological system of the river so profoundly as presently to render obsolete nuch that had been done and to call for a repetition of a consiclerable part of the work. The most important of these changes were, first, the introduction in 18.5 of the European carp and its rapid multiplication, until by 1908 its vield to the commercial fishermen was greater than that of all the other fishes of the river taken together: second, the completion and opening in Jannary, 1900. of the drainage canal of the Sanitary District of Chicago, greatly increasing the annomnt 
of raw sewage from the city of Chicago introduced into the Illinois at its source; and, third, a general movement for the reclamation of the bottomlands of the river for agricultural uses, by the construction of levees to prevent an overflow of the streams and by the drainage of bottomland lakes.

Our biological studies of the Illinois River have, of course, been carried on by the aquatic biologists of our own staft, but for a knowledge of the ecological conditions of an aquatic situation, an acquaintance with the chemistry of the water was essential, and this has been made possible to us by the generous cooperation, at first of the Department of Chemistry of the University of Illinois, which began analyses for us in May, 1894 , and since then by the Water Survey of the State which was organized the following year. These chemical studies became increasingly important as problems of stream pollution grew in prominence and led to the addition of a chemist to the river field party during the stmmer season of three years $(1911,1920,1922)$, to the analysis of weekly samples sent to the chemical laboratory in 1914, and to occasional trips to the river in other years by chemists of the IVater Survey, as called for by the biologists; and finally, upon the transfer of the main operations of the Natural History Survey to Rock River in 1925, the State IVater Survey took over the Illinois River program as a problem in river pollution, with its center of operations at Peoria, to which the Havana equipment had been transferred in 1920 .

The Natural History Survey still retains a permanent interest in the Illinois River, especially as a field for the solution of individual problems ; and it dealt with one such problem in 1926 and $192 \%$, when it made an exhaustive study of a new and remarkable disease of the European carp, traceable to the effects of pollution on the food supply of the carp. The Survey sustains also relations of cooperation with the Water Survey, to which it furnishes a biologist whenever his services are likely to be needed in elucidation of chemical conditions disclosed.

The place of the present bulletin in the series of which it is, in a sense, the final number, dealing as it does with the last twelve years of our active period on the Illinois, and discussing topics related to the whole range of our studies, may be made more evident by reference to the list of publications on the subject printed as an appendix to this paper.

Stephen A. Forbes. 


\section{CONTENTS}

Foreword, by Stephen A. Forbes.....................

Collections, dates. apparatus, river lesels................ 391

Rirer reaches covered. main hydrographical leatures. and principal collecting stations $[$ with map] . . . . . . . . . . . . . . . . 393

Load of sewage and industrial waste and zones of pollution [with

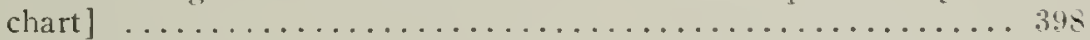

Classification of the species with reterence to degree of tolerance... 403

Some principal points regarding index value............ 110

Changes in the number of species taken and missing..........

Changes in the dissolved oxygen supply............... t20

Major changes in abundance of the more important groups....... 425

Changes in valuation as fish food and in per cent composition by-

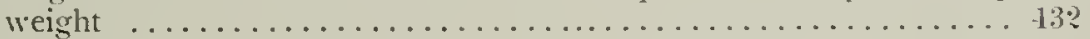

Temporal succession of the leading groups of polhutional or musually tolerant forms in the polluted reaches below Chillicothe....... 43 :

Competitive relations $\ldots \ldots \ldots \ldots \ldots \ldots \ldots \ldots \ldots \ldots \ldots \ldots$.

Accessibility. quality. and extent of use as fish food........... $4+4$

Changes in abundance of the principal groups during and just after the continuous smmmer floods of $192 \mathrm{t} t \ldots \ldots \ldots \ldots \ldots \ldots \ldots+48$

Comparative abundance in the chamel and extra-channel areas. 19:0

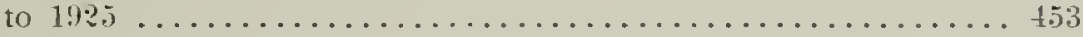

Changes in the mussel fama of Peoria Lake, 191 ? to $199.5 \ldots \ldots .4$. . .

Explanation of general tables........................

Summary ............................. 469

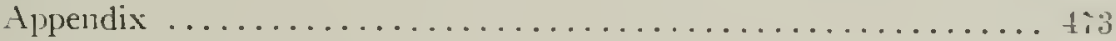




\title{
THE BO'TYOM FAUNA OF THE MIDDLE ILLINOIS RIVER, 1913-1925
}

\author{
Its I) istribution. Aloundance, Valuation, and Index Vatue \\ in the Siudy of Stream Pothution
}

\section{R. E. Richardson}

The present paper adds the findings of two more years (1924 and $1925)$ to our previous accumulation* on the small bottom fauna of the middle Illinois River, and brings into comparison with the data obtained under the comparatively clean-water conditions of 1:113-1!15 the results of five summers " collecting in the more or less seriously polluted botton muds in the same territory between the years 19120 and 192.5 . The dissolved-oxygen readings for the same or neighboring years have been furnished by the Illinois State Water Survey. The collection of the hiological material in 19:3 was the work of Dr. 1). H. Thompson of the Natural History Survey. The same part of the work in $1 ! 1 ? \pm$ and 192,5 was in the hands of Dr. H. I. Eigenbrodt. Especial thanks are also due to Dr. Thompson for considerable clerical work in the organization of recent data. and for valuable suggestions in the course of preparation of the manuscript.

\section{Collections, Dates, Apparatus, River Levels}

The statements contained in the present paper concerning the changes in the Illinois Kiver botton tauna during the twelve-year period, 19131925 , are mainly based on a total of it!! dredge and Petersen sampler collections taken between Chillicothe (1 $16 . j$ miles below (hicago) and the Lagrange Dam (?4!.5 miles below Chicago). Of these. 23: hauls. with varions dredges or with the mud dipper. were taken during the three years 1913-191\%. The remainder, 51: collections with the Petersen sampler. were taken during the summers of 1920 and $19 \cdot 9 \cdot 3995$. covering five

- Richardson, R. E. The Small Fottom and Shore Fauna of the Middle and Lower lllimois River and its Connecting Lakes. Chillicothe to Grafton: its Valuation; its Sources of Frod Supply; and its Relation to the Fishery. Bull. 111. Nat. Hist. Survey. Fol. Xi11, Art. $\mathrm{Xr}$, pp. 363-524, and maps: June, 1921.

Changes in the Bottom and shore Fauna of the Midlle Ininois Piver and its Connecting Lakes since 1913-1915 as a Result of the lncrease Southward of Sewage Pollution. Bull. 111. Nat. Hist. Survey, Vol. Xiv, Art. IV, pp. 33-75; December, 1921.

. Changes in the small Bottom Fauna of Peoria Lake, 1920 to 1922. Bull. 117. Xat. Hist. Survey. Vol. XV. Art. V pp. 327-3\&s, August, 1925. Survey, Fol. JV, Art. VT, pp. $391-422$; Cotober, in 1925. 
seasons. The $\$ 49$ collections mentioned were all taken either in the river proper or in the extra-channel portions of the expanded river above Peoria known as Peoria Lake, but include none from the smaller, more nearly inclosed, but connecting, bottomland lakes below or above Peoria. The distribution of these $: 49$ collections in time and their apportionment to river reaches was as follows:

\section{Number of} collections

1913 Chillicothe to Lagrange Dam....... 44

1914 Vicinity of Havana............. 13

1915 Chillicothe to Lagrange Dam....... 180

1920 Chillicothe to foot of Hickory Island. 71

1922 Chillicothe to foot of Peoria Lake... 71

1923 LaSalle to Beardstown.......... 158

1924 LaSalle to Beardstown.......... 13\%

1925 LaSalle to Beardstown.......... 75

Total ................

In addition to the above collections from the river and Peoria Lake there were taken in the river below Lagrange Dam in 1913 and 1915 a total of 153 hauls with dredges; and in the connecting bottomland lakes between Clear Lake (about 10 miles above Havana) and Meredosia Bay between 1913 and 1920 a total of 106 . The apportionment of these collections follows:

Number of

collections

1913 Illinois River, Lagrange Dam to Grafton (mouth of river) ...........

1915 Illinois River, Lagrange Dam to Grafton $\ldots \ldots \ldots \ldots \ldots \ldots \ldots \ldots \ldots \ldots \ldots \ldots$ i5

1913 Connecting bottomland lakes, Clear Lake to Meredosia Bay......... 113

1914 Connecting bottomland lakes. Clear Lake to Sangamon Bay..........

1915 Connecting bottomland lakes, Clear Lake to Sangamon Bay..........

1920 Connecting bottomland lakes, Liverpool Lake to Stewart Lalie........ 
Adding this group of bottom collections to the first list given, we have a grand total of 1,30 s dredge and Petersen sampler hauls taken between 1913 and 1925 in the Illinois River and immediately connecting waters; 406 of these coming from the smaller connecting bottomland lakes below Peoria; and 902 from the river proper and Peoria Lake.

The usual collecting period, in all years, has been June to September, with the larger part of the work falling in July and Angust. In the 1913-1915 period a small number of spring collections were taken, and in the antumn of 1914 work was extended to the end of October.

The collections of the small bottom fama in 1920 and 1922 were made without exception in the deeper open water, both of Peoria Lake and of the river, being thus confined to those areas where the effects of pollution were felt most fully, and where there was no unusual aeration or other protection afforded by coarse acpuatic regetation. In 19:3, 1924, and 1925 , a few collections were made near the margins. in the rather sparse new growths of regetation since 1920, but the data from those lots are excluded from the figures used in valuation, and the species there taken are segregated for special treatment in the arrangement of the lists of species taken in order of index value, and their discussion. Weed and edge species have been excluded also from all 1913-1915 data 11 sed for comparison.

River levels during all but two of the eight seasons of collecting from 1913 to 1925 were either unusually low or about average for the warm season of recent years. The summer of 191 .) was unusually wet, but apparently not sufficiently so to affect serionsly the distribution or the abundance of the bottom invertebrates. The summer of $192+$ had several successive floods that seem to be reflected in the bottom fauma figures for that year. For a brief further, statement on river levels, and some account of the effects of the floods of 1924 on the small bottom animals, see page +48 .

\section{River Reaches Covered, Main Hydrographical Features, and Principal Collecting Stations}

The portion of the Illinois River north of the Lagrange Dan corered either by the collections of $1913-1915$ or by those of $1920-1925$. or in both periods, has a length of 148 miles, lying between mile numbers 101.5 and 249.5 below Lake Michigan, or between LaSalle and the Lagrange Dam, respectively. This region of river breaks naturally into three main sections: the first, the 45 miles between LaSalle and the approximate head of Peoria Lake at Chillicothe; the second, the 19.9 miles of greatly expanded river between Chillicothe and the Peoria and Pekin Union Railway Bridge at Sonth Peoria, which we have assigned to Peoria Lake: and third, the 83.1 miles between the Peoria and Pekin Union Railway Bridge, or foot of Peoria Lake, and the Lagrange Dam. 
The 45-mile reach. LaSalle to Chillicothe, is mainly a sluggish, black-mud-bottomed section, with no important tributaries or other varying hydrographical features. except for the low dam at Henry, about three-fourths of the distance downstream from LaSalle. The effect of this dam is not important at either present or recent low-water stages, the swifter current immediately below continuing an almost negligible distance into the region of exceedingly low slope between there and Chillicothe.

The 19.9-mile section called Peoria Lake is made up, first, of tivo unusually wide and sluggish, mud-bottomed lakes or "wide-waters" (Upper and Middle Peoria Lake), about $\% .7$ and 6.8 miles in length, respectively; differing scarcely perceptibly in hydrographical character; and separated by a wide "narrows", of visibly faster-moving water which covers a distance of around three-quarters of a mile and has mud botton. The lower 5.t miles of this 19.9-mile section (Lower Peoria Lake) is both shorter and narrower than either the Upper or Middle Lake; has a distinctly swifter average current, relatively much wider channel and correspondingly narrower "lake" or "wide-water" portion; and is separated from the Middle Lake, at Peoria Narrows, by a narrow neck about one-half mile in length, with unusually fast current and generally well washed, lightly silted, and Bryozoa-covered bottom.

The 83.1 miles between the foot of Peoria Lake and the Lagrange Dam presents a great variety hydrographically, having alternating swift and sluggish reaches, a dam (Copperas Creek) about one-fourth of the way down, two tributaries of considerable size (Mackinaw and Spoon Rivers, the first important ones below LaSalle) between PeoriaPekin and its midway point, and another still larger tributary (Sangamon River) about 10 miles above its lower end. For purposes of convenience, mainly, we have broken it up, in various comparisons, into five sections; the first four being short ones, covering only the first 40.6 miles below the foot of the Lake and ending just below Spoon River at Havana: and the fiftl covering the entire remaining 42.5 miles between Havana and the dam at Lagrange.

The four upper short reaches recognized between the foot of $\mathrm{Pe}$ oria Lake and Havana, in their turn, break into two groups at the Copperas Creek Dan, 23.8 miles below the foot of Peoria Lake. The upper 23.8 miles, again, has a natural break at Pekin, due to the access there of large additional factory wastes and to the marked slowing up of current that begins very shortly below that point as a consequence of the backing effect at low water of the Copperas Creek Dam. Also, the 16.8 miles between Copperas Creek Dam and Havana has a more or less natural dividing line about one mile above Liverpool, marking roughly the complete subsidence of the faster flow following the fall over the crest of the dam, and the entrance into the very sluggish deepsoft-black-mud-bottomed pool lying between that point and the Spoon River bar about 9 miles south. 
The stretch of 42.5 miles between Havana and the Lagrange Dam covered in the seasons 1913-1915 is much more uniform over most of its length than the Peoria-Havana section. Sand, sand and shell, hard clay, or very lightly silted soft bottom is the rule throughout this stretch with the single important exception of a few miles of more heavily silted bottom lying inmediately above the Sangamon River bar, about 5 miles above Beardstown and about 1.j miles above Lagrange.

The scheme of main reaches and subdivisions and a list of the principal sampling stations, or location of cross-sections, with distances below Lake Michigan, will be found in Tables I and II, respectively.

\section{TABLE 1}

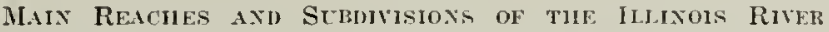

Coveren by Compalamle, Bottom Fat'ya Series, แOTH 1913-1915 AXU 1920-1925

\begin{tabular}{|c|c|c|}
\hline Reaches and subdivisions & $\begin{array}{l}\text { Distance } \\
\text { in miles }\end{array}$ & $\begin{array}{c}\text { Upper and lower } \\
\text { mile numbers } \\
\text { (below Lake Michigan) }\end{array}$ \\
\hline
\end{tabular}

Chillicothe to Foot of Peoria Lake........ 19.9

$146.5-166.4$

Upper Peoria Lake............... 7.7

$146.5-154.2$

Middle Peoria Lake................

6.8

$154.2-161.0$

Lower Peoria Lake....................

$161.0-166.4$

Foot of Peoria Lake to Lagrange Dam......

\$3.1

$166.4-249.5$

or Foot of Peoria Lake to Beardstown......

71.6

$166.4-238.0$

Foot of Peoria Lake to Copperas Creak

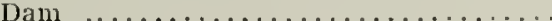

Foot of Peoria Lake to Pekin.......

23.8

$166.4-190.2$

Pekin to Copperas Creek Dam.......

$166.4-174.0$

16.2

$174.0-190.2$

Copperas Creek Dam to Havana.........

16.8

$190.2-207.0$

Copperas Creek Dam to 1 Mile above

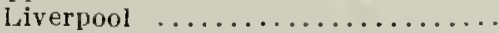

1 Mile above Liverpool to Havana....

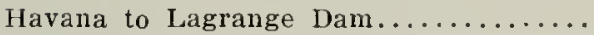

42.5

$207.0-249.5$

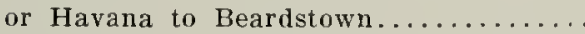


TABLE II

Location of Principal Sampling Stations

(BotToM FAUNA AND DISSOLVED OXYGeN)

ILLINOIS RNER, 1913-1915 TO 1925

\begin{tabular}{|c|c|c|}
\hline Sampling stations & Distance & $\begin{array}{l}\text { below Lake Michigan } \\
\text { in miles }\end{array}$ \\
\hline$\ldots \ldots \ldots \ldots$ & 101.5 & \\
\hline Spring Valley $\ldots \ldots \ldots \ldots \ldots \ldots \ldots \ldots$ & 108.6 & \\
\hline Hennepin $\ldots \ldots \ldots \ldots \ldots \ldots \ldots \ldots$ & 119.5 & \\
\hline 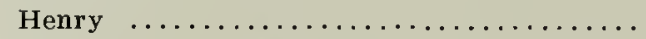 & 131.0 & \\
\hline 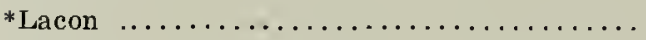 & 137.8 & . \\
\hline Chillicothe $\ldots \ldots \ldots \ldots \ldots \ldots \ldots \ldots$ & 146.5 & \\
\hline 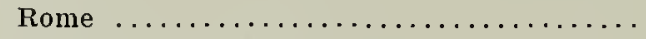 & 149.3 & \\
\hline Foot of Partridge Island............ & 151.0 & \\
\hline Spring Bay $\ldots \ldots \ldots \ldots \ldots \ldots \ldots \ldots$ & 153.2 & Yupper Peoria Lake \\
\hline Spring Bay Narrows................ & 154.0 & \\
\hline Mossville $\ldots \ldots \ldots \ldots \ldots \ldots \ldots \ldots \ldots$ & 154.9 & \\
\hline Maple Point $\ldots \ldots \ldots \ldots \ldots \ldots \ldots$ & 156.6 & \\
\hline Long Shore Beach................ & 158.2 & Middle Peoria Lake \\
\hline Opposite center of Towhead Island........ & 158.8 & \\
\hline 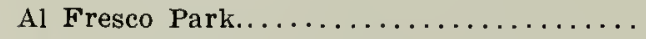 & 159.3 & \\
\hline Peoria Narrows $\ldots \ldots \ldots \ldots \ldots \ldots \ldots \ldots$ & 161.0 & \\
\hline $\begin{array}{l}\text { U. S. Slips (approximate equivalent of } \\
\text { Averyville of early collections) ......... }\end{array}$ & 162.8 & Lower Peoria Lake \\
\hline Main Street, Peoria............... & 164.2 & \\
\hline Peoria and Pekin Union Railway Bridge... & 166.4 & \\
\hline 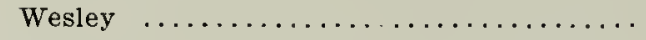 & 167.8 & \\
\hline Head of Seven Mile Island............. & 170.0 & \\
\hline 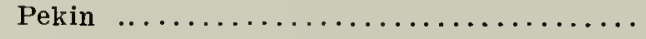 & 174.0 & \\
\hline 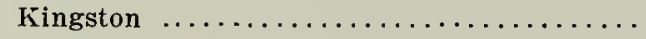 & 181.5 & \\
\hline Copperas Creek Dam................ & 190.2 & \\
\hline Liverpool $\ldots \ldots \ldots \ldots \ldots \ldots \ldots \ldots \ldots \ldots$ & 199.0 & \\
\hline 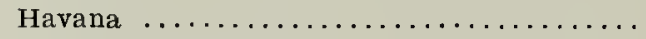 & 207.0 & \\
\hline Foot of Matanzas Lake................ & 212.5 & \\
\hline 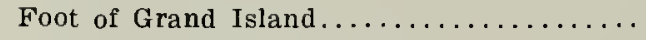 & 220.2 & \\
\hline Head of Hickory Island............. & 226.3 & \\
\hline Foot of Hickory Island.............. & 228.2 & \\
\hline 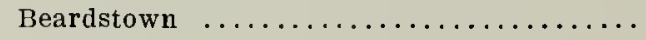 & 238.0 & \\
\hline $\begin{array}{c}\text { Lagrange Dam }(77.5 \text { miles above mouth of } \\
\text { River at Grafton }) . . \ldots \ldots \ldots \ldots \ldots \ldots \ldots\end{array}$ & 249.5 & \\
\hline
\end{tabular}

* Quantitative bottom fauna collections between LaSalle and Lacon only in 1923 and after. 


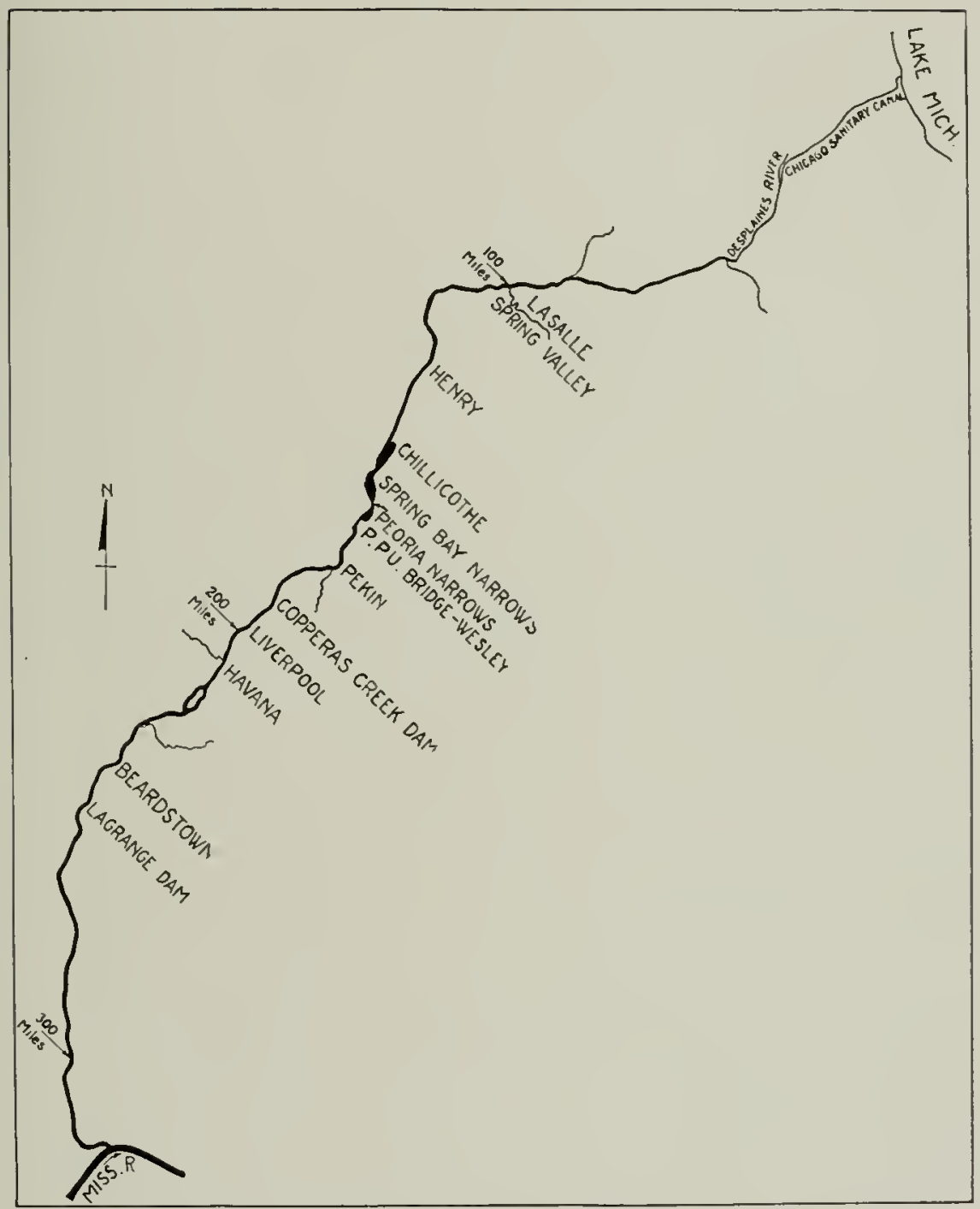

Sketcil Map of tie Illixols River, Silowisg Locatiox of Prixcipal SAMPLIXg STatioxs 


\section{Load of Sewage and Industrial Waste and Zones of Pollution}

In the summer of 1914, when the small bottom fauna and the fish fauna of the central portion of the Illinois River, between the head of Upper Peoria Lake and the Lagrange Dam, were both in all their larger features for practical purposes normal, the population of the City of Chicago, more than 140 miles above the head of Peoria Lake, was estimated as $2,437,526$, and the population equivalent of the wastes from animals slaughtered at the Chicago Stock Yards was approximately 869,000 persons additional. At that time Peoria and Pekin and suburbs had a combined population of about 86,000 and industrial wastes of unknown population equivalent, though thought to amount to several hundred thousand persons; but all these wastes were absorbed without noticeable effect upon the small bottom animals and without depressing the dissolved oxygen unduly. By 1920, the Chicago population is estimated to have increased around 10 per cent, to about $2, \% 01,000$; and the stock yards wastes, in population equivalent equal to $1,040,000$, were about 19 per cent greater than in 1914, after having fallen off 353,000 since the peak of the war-time activity of 1918 . Between 1914 and 1920 , all of the wastes from the sources above described were received by the Sanitary Canal and Illinois River wholly untreated and subject after delivery only to the effects and processes of dilution and biological purification, varying with river levels, temperature, and other physical conditions, as chance might offer.

Between $191 t$ and 1920 , the increase in the combined population of Peoria and Pekin and suburbs, estimated to have been over 11 per cent, but amounting to only about 10,000 in actual human units, was too small to account for any measurable part of the unfavorable changes below those two cities. During the same period, however, there is known to have been large increase in the grind of corn at the Corn Products Refining Company's plant at Pekin, so that the wastes from this plant were increased by an amount possibly almost equivalent to the combined wastes from the human population of the two towns.

Other untreated wastes from the City of Chicago and environs, of which we have incomplete record, included between 1914 and 1920 that from some 300,000 so-called floating population, temporarily in hotels, etc. : as also the wastes from the Corn Products Refining Company's plant at Argo, a suburb of Chicago, and from other industries outside of Packingtown, amounting in all probably to several hundred thousand additional population equivalent. The changes in all these items between 1914 and 1920 were with little doubt upward, in unknown amount, with those at the Argo plant of the Corn Products Refining Company probably holding a leading place in importance. During this six-year period the growth of the other small up-river cities between Peoria-Pekin and Chicago, while relatively considerable, is not thought 
to have been important in comparison with the other sources of upriver wastes named. All of the Peoria and Pekin wastes, those from Chicago additional to the Packingtown wastes and the sewage of the residential population, as well as the wastes from the mostly small upriver centers of population between Chicago and Peoria were, as was trute of the Chicago Stock Yards and resiclential sewage and that from Pekin and Peoria, received in the raw state, up to and sonewhat after 1920. A saving feature of the situation, however, both before and since 1920, has been the fact that, with the exception of the Peoria and Pekin wastes above described, there has been at no time any important contribution of pollution from down-state sources along the Illinois River. Below Peoria and Pelin, in fact, with 150 miles of the trip to the mouth still unrun, such anounts of house sewage and industrial waste as have been received have always been negligible.

The changes in the anounts of waste received from the various sources above mentioned between 1920 and 19:5. so tar as we have any account of then1, were by no n1eans miformly in one direction. but, so far as they affected materials received from Chicago and ricinity, seen to have about balanced each other in toto. These shifts evidently included an unusually heavy rate of increase in the city's human population, which is, in fact, currently estinlated as laving increased by $400,000-1,000,000$ between 1920 and $19 ? 2$. But to offset this increase, considerable construction of the new sewage treatment plants has already been completed: and there has been reported an 80 to 90 per cent reduction in the anlount of waste received from the Corn Products Refining Conusany's Argo plant, amonnting by itselt possibly to a few hundred thousand persons, in population equivalent. Further than the fact that the annual pack has recently continned large, we have no infornlation on changes in the rolume of Packingtown wastes in the last few years.

Changes between 1920 and 1925 at Peoria-Pekin, though largely: conjectural, seen since $192 \pm$ to have been on the whole in a downard direction, if we are to draw conclusions from recent changes upward in the dissolved oxygen supply at points below the Copperas Creek Dan. The movement of the population figures during these five years was of course upward, but in too small numbers to affect the sanitary indices noticeably. An apparently much more possible source of the recent improvement below Peoria seens to be in the improvement of the methods of waste disposal used by the Corn Products Refuning Connpany at Pekin, which, it is presumed, nuade inproved clarifying installations at Pekin at or near the same time it made them at Argo (Chicago).

The earlier of the natural reduction processes affecting the organic wastes from Chicago and its suburbs, so far as they occur in the Sanitary Canal and the Illinois River, take place now, as fifteen or more years ago, principally in the first hundred nules outside of the city. 
The location of the great septic (polysaprobic) zone, or zone of Sphacrotilus natans, lies within this territory, above the city of LaSalle, and does not come within the boundaries of the studies undertaken in this paper. The 136 to 148 miles of the Illinois lying between LaSalle and Beardstown or Lagrange Dam (the latter point located about if niles above the mouth of the river) has in recent years been early pollutional to late sub-pollutional (early mesosaprobic alpha to late mesosaprobic bcta in the sense of Kolkwitz and Marsson*), and is briefly characterized by sections and dates, in the paragraphs that follow.

\section{LaSalle to Chillicothe}

This stretch of 15 miles, which in 1911-1912 was early pollutional to early sub-pollutional (early mesosaprobic alpha to early mesosaprobic bcta) has all been early pollutional (early mesosaprobic alplaa) since 1920 ; with bottom oxygen near or at the zero point and Tubificidac running into hundreds of thousands per square yard in the sumnner season.

\section{Uppor Pcoria Lake}

If some relatively sniall areas near shore be excepted, the $\% .7$ miles of Upper Peoria Lake is apparently best described as early to late pollutional (mesosaprobic alpha) in years since 1920. Improvement in sanitary condition is relatively rapid in this short distance, under the influence of retarded current, widely and thinly spread waters, and accelerated growth of an incipient chlorophyllaceous phytoplankton, which had been held back by the conditions prevailing above Chillicothe. The same section narked the lower limit of the sub-pollutional zone (mesosaprobic bcta) in $1913-1915$.

Middlc and Lozer Peoria Lakc

Though conditions are mixed, particularly in the lower end of this reach of 12.2 miles, the section may be described, as of seasons since 1920, as principally early sub-pollutional (early mesosaprobic bcta). The improvement in the bottom muds that took place in the 6.8 miles of the Middle Lake is checked, even in the greater part of the widewaters below Peoria Narrows by wind or wave-borne local pollution from the Peoria sewers. In both the Middle and the Lower Lake the dissolved oxygen, particularly at the surface, frequently goes quite high, but is not a good index of conditions on the bottom, in recent years. This territory was, if small areas near the Peoria water front on the Lower Lake be excepted, principally early clean-water (early oligosaprobic) in 1913-1915.

* MJarsson, M., Die Bedeutung der Flora und Fauna der natürlichen Gewässer für ihre Reinhaltung sowie inre Beinflussung durch Abgänge von Wohnstâtten und Gewerben. Mittlgn. d. Prüfungsanstalt. f. Wasservers. u. Abwbes. Heft. 14; 1911.

Kolkwitz, R., et al., Wasser und Abwasser: Die Hygiene der Wasserversorgung und Abwasserbeseitigung Leipzig, 1911, pp. 1-410; section on biology of sewage effuents, pp. $337-383$, and plates. 


\section{P.P. U. Bridge to Haz'ana}

This section of to.r miles also presents more or less mixed conditions: receiving the wastes of the Corn Products Refining Company's plants at Pekin, i.6 miles down; and having a dam at Copperas Creek, at the end of the first 23.8 miles. Since 1920 , conditions above the dam have ranged from pollutional to early sub-pollutional (mesosaprobic alpha to early mesosaprobic beta) over nost of the area, and have apparently been largely early sub)-pollutional (early mesosaprobic bcta, in the same period below the dam. In 1913-1915 all this territory was cleanwater (oligosaprobic) in the sense as usually understood. For a brief discussion of the visible increase since 1923 in the dissolved oxygen supply in the portion of this zone lying below Copperas Creck Dam, (without corresponding improvement being reflected in the small bottom fauna up to 1925) see the sections on dissulved oxygen, following.

\section{Hacana to Bcardstoam. or \\ Hac'ana to Layrange Dam}

The 31-mile section of river between Havalla and Beardstown (corresponding to the 4:.5 miles between Havana and Lilgrange, 1913-1!1j) seems to have been mostly late sub-pollutional (late mesosaprohic bela) from 1920 to 1923, , but to have shifted strongly, as indicated by the dissolved oxygen supply, toward early clean-water (oligosaprobic) between 1923 and 1925, though not yet very clearly so on the lasis of the bottom fama. This change. apparently largely a consequence of improvement in waste disposal at the Com Products' plants at Pelin, is illustrated by the bottom dissolved oxygen figures in a subsequent section. All of this portion of the river was late oligosaprobic in $191:-1915$.

The approximate equivalence of zones from the head of Peoria Lake sonth in the $1911-1915$ and the 1920-1925 periods may be expressed finally as follows: Upper l'eoria Lake in 1920-1925 about the same as LaSalle-Spring Valley in 1911-1912 (early pollutional): upper portion of Havana-Reardstown reach about the sane in 19:0-19?3 as Upper Peoria lake in 1913-191.5 (late sul-pollutional): lower portion of reach Havana-Beardstown shifting after $19 \% 3$ toward the condition of the best open water portions of Middle and Lower Pcoria Lake in 1!9131915 (early oligosaprobic). The diagrammatic summary at the end of this section illustrates clearly the favorable effect of the first expansion of the river between Chillicothe and Spring Bay Narrows in checking the extension southward of the upper pollutional area between 1911-191? and 1920-1925. Thus, the approximate boundary line between the pollutional and sub-pollutional zones abor'c Pcoria moved down stream not nutch if any nore than 10 miles (or about the length of Upper Peoria Lake) between 1913-1915 and 19:0; whereas the boundary between the late sub-pollutional and clean-water, lying in 1913-1915 much closer to the faster current of the Lower Lake. moved more than 50 miles (or from some point in Middle Peoria Lake to Havana or below) in the same time. 


\section{CHART SHOWING SHIFTING OF ZONES OF POLLUTION}

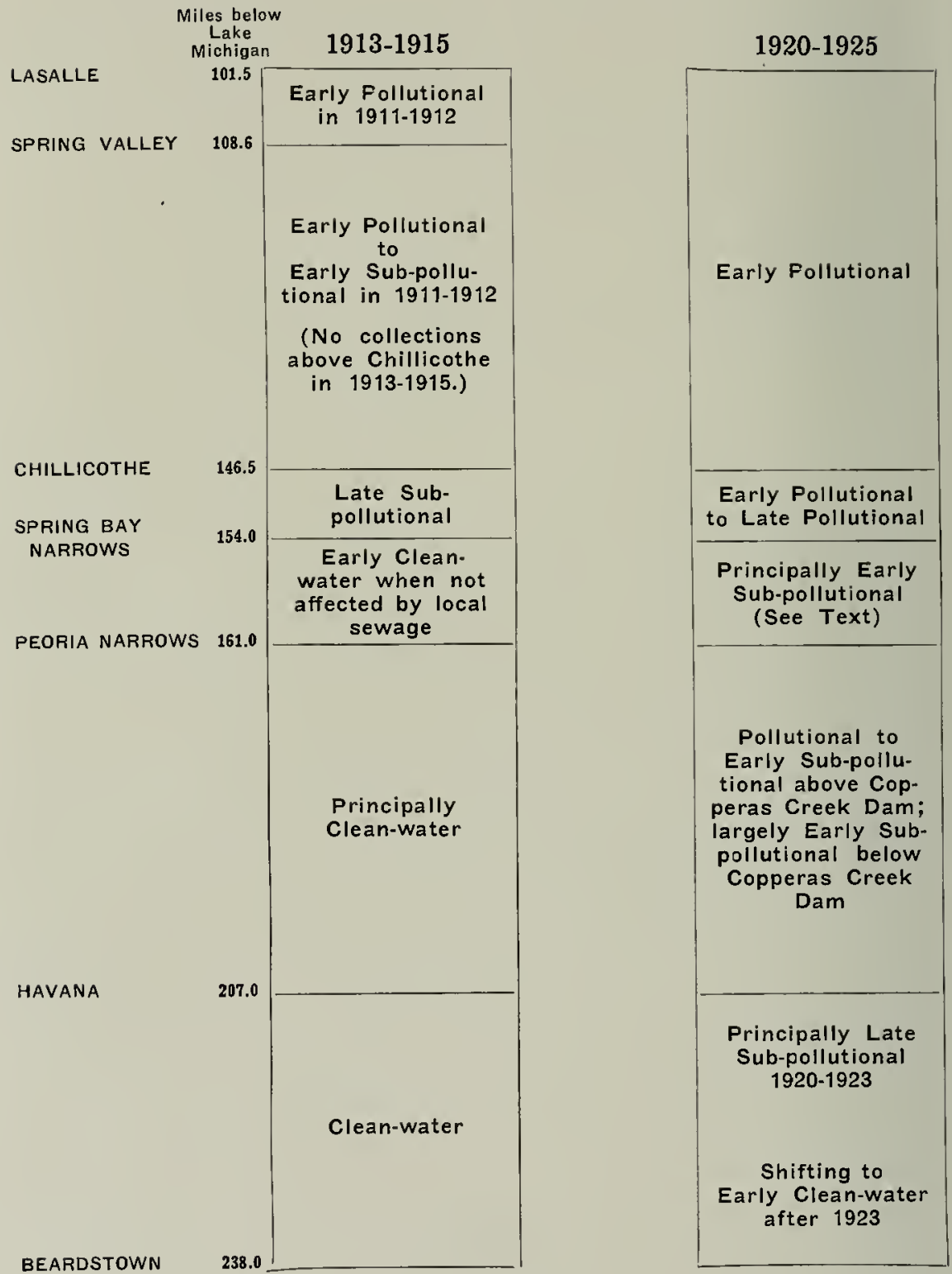




\section{Classification of the Species with Reference to Degree of Tolerance}

In the comparisons later made in the present paper, illustrating changes in the composition of the small bottom fauna since $191 \mathrm{j}$ in the Illinois River between Chillicothe and Beardstown. seren main groups of species have been recognized in the arrangement of the various kinds in order of tolerance, as follows:

I. The pollutional group, embracing seren or eight species that usually reached their highest figures 19120 to 19.25 in or above $L_{p p e r}$ Peoria Lake. Here are included two genera and not less than five or six species of Tubificidac and at least two linds of midge larvae.

II. The sub-pollutional group, unusually tolerant subdivision: fifteen species, including several each oi Sphacriidat. leeches. midge larvae, and Bryozoa. These have an musually wide range of adaptability under changing conditions; all of them are apparently nommal to the cleaner-water zones, but also quite capable of subsisting, and sometimes attaining very large numbers, either in pollutional or sub-pollutional territory. The most important of these from the point of view of numbers is the small bivalve nollusk, Musculium transacrsum, of which we have records in multiples of ten thousand per square yard under the widely varying conditions of the comparatively clean lower and middle lllinois River in 1913-1915, and of the lower pollutional to upper sub-pollutional territory of $\mathrm{L}^{\prime}$ per P'eoria Lake between 1!1:0 and 1925. This small bivalve, as well as several midge larvae and leeches. is frequently very closely associated with the more pollutional Tubificidac where they occur in greater numbers: and it has been taken since 1920 in numbers around three hundred per square vard at points in the polluted Illinois fully jo miles above those points in Lper Peoria Lake where the last zero oxygen readings have recently been taken as we pass downstream.

III. The sub-pollutional group, unusually tolerant or doubtful subdivision. Here are included several miscellaneons midge larvae. partly incompletely determined, which had a range $1 ! \cdot 00-19 \cdot 5$. a!l the way from Henry i 15.5 miles above the head of Peoria Lake) to Havana and farther south.

IV. The sub-pollutional group, less tolerant subdivision, a mised lot of more than twenty species, largely Chironomidac and Splacridac: and also including one gastropod, one leech, a lew worms. and a few dwarf or young [nionidac. These ranged all the way from the upper end of Peoria Lake to Havana and south, under the cleaner-water conditions prior to 19:0, but since 19:0 have apparently done better under the sub-pollutional conditions between Chillicothe and the foot of Peoria Lake than in any part of the river between Peoria and Beardstown. 
V. Pulmonate snails and air-breathing insects, five species. These are locally common, usually near the edge, or in unusual current, or in a situation combining both, in 1924 and 1925 collections as far north as Rome (upper end of Upper Peoria Lake) ; and we have taken them elsewhere in Illinois in sinnilar situations under conditions that can be classed only as pollutional. The normal preference of all these surface and edge forms is for clean water, and they are wholly lacking in index value in connection with the study of stream pollution.

VI. Current-loving species other than pulmonate snails and airbreathing insects, with normal preference for cleaner water, but able to endure the conditions of the sub-pollutional zone in case there is unusual current. Here are placed a dozen or more kinds in all, including two Plcuroccridac, one isopod (Ascllus intcrmcdius), several sponges and Bryo $\approx o a$, and several Hydropsychidae, the latter all undetermined, but of known habit and distribution. The index value of these species, though without question they are to be regarded for the most part as strictly clean-water forms, is poor, and their inclusion in lists without qualification is very likely to be misleading.

VII. Cleaner-water species, about thirty species in all, including a limited number of Crustacca and Bryosoa; several snails each of the families Valvatidac, Amnicolidac, and $\dot{V}$ iviparidac; a few kinds of dwarf or young Unionidac; a few kinds each of immature Ephemcridac, Odonata, and Chironomidac; an immature sialid; a few immature Trichoptera; and a few adult or larval Colcoptcra. It has been convenient to subdivide this group, from the Illinois River 1920-1925, into a less sensitive and more sensitive subdivision, each including about half of the total as given.

Of the less sensitive subdivision we noted occasional occurrences 1920 to 1925 in the open water of the sub-pollutional zone (Middle Peoria Lake), though the majority of occurrences recorded at stations ahove Copperas Creek Dam in this period were from the edges. These species normally belong to the clean-water zones south of Peoria, but seem to have been largely exterminated there between 1915 and 1920 , and not yet to have been reestablished in important numbers. The index value of the few occurrences in Peoria Lake recently is doubtful, because of the possible existence of springs under the lake bed there, as is known to be the case in the immediate vicinity of Spring Bay.

The more sensitive subdivision of the cleaner-water group includes species which have been confined in recent years to the edges or to unusual current, in cases where they do occur at all at points in Peoria Lake or elsewhere above Copperas Creek Dam. Most of these, like the less sensitive group, are recently absent or very rare in the reaches of river between Copperas Creek Dam and Beardstown, though most of them were common there, at least locally, in the period 1913-1915. Occurrences of members of this group at edges have no index value.

In the following list of small bottom invertebrates, upwards of one hundred kinds (if allowance is made for several cases of two or more 
undetermined forms grouped together) taken in the Illinois River since 1920 in the 136.5 miles betwec-11 LaSalle and Beardstown are assigned places in one or another of the seven gronps above outlined. Lnder each group, and to a considerable extent throughout the entire list. account is taken in each case of farthest northward occurrence in the more polluted sections of the Illinois River studied since 19?0. Other considerations taken into account in determining the order of artangement. of pollutional or unusually tolerant species in particular, have been: outside data on distribution and tolerance to pollution: association with other species of known pollutional or tolerant habit: survival under conditions of low dissolved oxygen supply, or where formerly-present clean water forms have been destroyed: and, in general, relative abundance or rarity before and since the great increase in pollution in and below Peoria Lake about ten years ago. All of the records have been considered in the light offered by data on the dissolved oxrgen: as well as the usual or umusual phrsical or hydrographical factors that migit be concerned. For just as the pollutional or unusually tolerant kinds may have an extreme range that carries them far outside of the pollutional or sub-pollutional zones downstream into relatively clean water. so nuay many of the clean-water species-under the protection of unusual current, or spring water. of proxinnity to aquatic vegetation. or to the margins (where the wash, or wind and wave effects, result in mechanical reaeration)-advance long distances upstrean occasionally into the more polluted zones. These exceptional nccurrences in all the more important instances, have been given separate listing: this is a point of especial inportance in Peoria Lake recently in the case of severai cieanwater forms found sparingly in restricted situations outside of their general boundaries. and likely to mislead the inexperienced worker into assuming a much greater degree of improvement in sanitary condition than las actually occurted orer the major part of the area in the time covered by the observations.

In the complete list of species of small bottom anmals that follows, a haif dozen of the names, annong the first 1 ? entries. are marked with one or two stars $(* * * *)$, the latter number signifving unnsual index value. The six started kinds include all taken between 1490 and 1925 in the pollutional to late sub-pollutional territory between LaSalle and Beardstown that occurred in large enough numbers to be listed as common or abundant. Brief notes concerning the index value of these six species accompany their names in the rumning list. Some further discussion of nain points concerning the value of the sniall bottom invertebrates as indicators of pollution, as based on out recent Inlinois River data, will be found in the special section on that topic next following. The relatively tew cleaner-water kinds taken at openwater stations in the sub-pollutional sections between Middle Peoria Lake and Beardstown since $19 ? 0$ were in no case present in average numbers more than negligible as compared with the abundance of the same or similar kinds in the same territory in the $1913-1915$ period. 
List of Species of Shale Botron Aximals Takex in the Illixols River, LaSalle to Bearnstown, 1920 to 1925, ArRaxged ix Approximate Order of TOLeraxce

\begin{tabular}{l|l}
\hline Classification & $\begin{array}{c}\text { Farthest upstream occurrence } \\
\text { in open } \dagger\end{array}$ \\
\hline
\end{tabular}

1. Pollutional; in general, more common in the pollutional zone than below it.

**1. Tubifex tubifex. A species of unusual index value; frequently reaches very large numbers in the lower end of the septic or apper end of the pollutional zone.

**2. Limnodrilus hoffmeisteri. Likely to occur in extremely large numbers throughont the pollutional zone. Index value somewhat less certain than that of the preceding species.

3. Limnodrilus sp. 3

4. Limnodrilus sp. 4

5. Tubifex sp.

**6. Chironomus plumosus, var., larva. Frequently occurs in very large numbers throughout the pollntional zone, though much less regularly so than $L i m n$ od $r i l u s$ hoffmeisteri. Ventral blood gills vary in length as dissolved oxygen increases or decreases. Not taken by us in the septic zone of the Illinois River except at edges.

7. Chironomus decorus, larva

8. Limnodrilus elaparedianus

II. Subpollutional, unusually tolerant; common to abundant at some stations in the pollutional zone; but with original natnial preference for the subpollutional or cleaner water zones.

*9. Musculium transversum. Extremely abundant in the pollutional zone in company with Limnodrilus hoffmeisteri, Tubifex tubifex, and Chironomus plumosus. No index value; equally common in some situations on clean bottom, and believed to be a case of recent adaptation.

*10. Chironomus lobiferus, larva. Occasionally or locally abundant in the pollutional zone; evidently has a distinct pollntional habit; but of too irregular occurrence to have great index value.

11. Musculium truncatum

LaSalle

LaSalle

Lasalle

Hennepin

Henry, above dam

Henry, above dam

Lacon

Chillicothe

LaSalle

LaSalle

*12. Hclobdella stagnalis. Occasionally or Hennepin

**;* For meaning of stars preceding names of species, see p. 405 .

$\dagger$ With exceptions noted on p. 409. 
Table III-Continued

locally abundant in the pollutional and subpollutional zones; but mo definite connection with poliution, as such, apparent.

13. Inina microstoma

14. Glossiphonia complanata

15. Pisidium compressum

16. Tanypus sp. 1. larva

17. Tanypus sp. 3. larva.

15. Plumatella princeps var. mucosu

19. Dina yerver

20. Plumatella princeps var, fruticosa

21. Erpobdella punctata

22. Helobdella nepheloidea

23. Hyalella knickerbockeri ${ }^{2}$

III. Sub-pollutional, unusually tolerant or doubtful: species undetermined; numbers not important.

24. Tenymus sp., larva

25. Chironominae. gen. and spp., undetermined, larvae

26. Tamypinac. gen. and spp., undetermined, larvae

27. Chironomus sp., larra

IV(a). Sub-pollutional, less tolerant, more common species; normally preferring clean water; but able to stand sub-pollutional conditions even where the current is slight.

2S. Pisidium yauperulum var. crystal. ense

29. Pisidium complanatum?

30. Sphacrium striatinum var. corpulentum

31. Camprloma subsolitum

32. Pisidium sp.

33. Sphaerium striatinum var. litycrshense

34. Sphaerium stamincum

35. Proclatius compinuus. larva

36. Cryptochironomus digitatus, larva

IV(b). Sub-pollutional, less tolerant, less common species; normally preferring clean watel: but able to stand sub-polhutional conditions even where the current is slight.

37. Tinypus dyari. larva

3S. Tanypus momilis. larva

39. Procladius sp. larva

40. Uligochacta. gen. and spp. undetermined

41. Palpomyia sp., larva

42. Plicobilclla rugosa.

43. Anorionta imbecillis

44. Lampsitis sp., young.

45. Naidictuc. gen. and spp. undetermined
Hennepin

Hennepin

Henry, above dam

Lacoll

Lacol?

Lacon

Lacon

Chillicothe

Chillicothe

Chillicothe

Henry, below dam, in current

Henry, below dam

Lacoin

Lacon

Chillicothe

Rome

Rome

Rome

Rome

Spring Bay

Spring Bay

Spring Bay

Spring Bay

Spring Bay

Rome

Rome

Rome

Rome

Spring Bay

Spring Bay

Mossville

Mossville

Mossville

${ }^{1}$ This species was taken as far north as spring Valley in 1911-1912. 


\begin{tabular}{c|c}
\hline Classification & $\begin{array}{c}\text { Farthest upstream occurrence } \\
\text { in open water }\end{array}$ \\
\hline
\end{tabular}

46. Fordidae, gen. and spp. undetermined

47. Orthocladius sp.

48. Lampsilis gracilis, young.

49. Polypedilum sp., larva

V. Pulmonate snails and air-breathing insects; locally commou near edges or in unusual current, of either pollutional or subpollutional zone; index value none; normal preference for clean water.
50. Physa sayi
51. Planorbis trivolvis
52. Arctocorisa sp.
53. Lymnaea humilis
54. Ferrissia rivularis

V1. Current-loving or edge-dwelling, purely aquatic species, able to endure conditions in the sub-pollutional zone provided there is more tban usnal current; numbers small; index value poor.

55. Planaria, gen. and spp. undetermined

56. Asellus intermedius

57. Dero sp.

58. Spongilla fragilis

59. Pleurocera acutum

60. Goniobasis livesccns

61. Plumatella princeps var. mucosaspongiosa

62. Hydropsyche, spp. undetermined (at least four), larvae

63. Urnatella gracilis

64. Paludicella. ehronbcrgii

VIl(a). Cleaner-water species, less sensitive group; occasional occurrences in open water in the sub-pollutional zone, but usually taken 1920 to 1925 only at or near edges in Peoria Lake and at other stations above Copperas Creek Dam; these species normally belong to the clean-water zones, below Havana, at present, but are rare and scattering even there since 1920 . Index value of occurrences in open water in Peoria Lake doubtful in several cases, because of possibility of existence of springs under the lake bed. (See also pp. 454-458, on Unionidae.)

65. Valvata tricarinata

66. Valvata bicarinata var. normalis
Long Shore Beacl

Wesley, strong current

Wesley, strong current

Seven Mile Island, strong current

Rome

Rome

Peoria Narrows, strong current

Peoria Narrows, strong current

Peoria Narrows, strong current

Spring Bay, current Spring Bay, current Peoria Narrows, current Peoria Narrows, current Peoria Narrows, current Peoria Narrows, current Peoria Narrows, current

Peoria Narrows, current

McKinley Bridge, current McKinley Bridge, current

*Mossville

*Mossville 
T.HBLE III-Conctuded

67. Carnis sp. 1, nympl

68. Talvata bicarinata

69. Tivipara contectoides

70. Amnicola emarginata

71. Sialis infumata, larva

72. Pfetimatella magnifica

73. Plumatella polymoryha var, repens

74. Gomphus plagiatus, nymph

75. Gompluus rxternus, nymph

VIl(b). Cleaner-water species, more sensitive group; occasional occurrences, at edges or in unusual current only, at stations between upper end of Middle Peoria Lake and Copperas Creek Dan. Most of them still absent or very rare in the reaches between Cop. peras Creek Dam and Beardstown, though most of them were formerly common there at least locally. Index value none when they occur at edge.

76. Tropisternus arsalis, adnlt

77. Ischnura verticalis, nymph

78. Lampsilis parvus

79. Vivinara subpurpurea

S0. Lioplax subrarinatus

81. Anax junius, nymph

S2. Rhyucophiza sp., larva

83. Amnicola limosa

84. Enallagmu signatum

85. Somatogyrus subalobosus

86. Leptocerianc, gen. and spp. undetermined, larvae

87. Palacmonctes critipes

S8. Heragenin bilineata, nymph

89. Corlylophora lecustris

Vll(c). Cleaner-water species, more sensisive group; not taken above Copperas (reek Danı at all in yeal's since 1920 ; and only scattering occurrences below Copperas Creek Dam in recent period; the last named, Chironomus femugineovitutus, was very common in Illinois River black muds as far north as Copperas Creek Dam in 1913-1915.

90. Truncilla donaciformis

91. Truncilla elegans

92. Polyefntropus sp., larva

93. Molanidac, gen. and spp. undetermined.

94. Chironomus fermuincovittatus, larva
*Mossville

* Maple Point

*Maple Point

* Maple Point

*Long Shore Beach

*Al Fresco

* Wesley, current

* Tingston

* Kingston

\author{
$\dagger$ Rome \\ $\dagger$ Rome \\ $\div$ Mossville \\ $\div$ Mossville \\ †Mossville \\ $\div$ Mossville \\ $\dagger$ Mossville \\ † Long Shore Beach \\ $\doteqdot$ Al Fresco \\ -Peoria Narrows, current \\ $\rightarrow$ Peoria Narrows, current \\ †eoria Narrows, current \\ †Pekin, one occurrence, 1923 \\ †ingston, one occurrence \\ 1923
}

Havana

Matanzas

Copperas Creek Dam, below Havana

\section{Matanzas}

* Fartliest north in open water.

t Farthest north at elges or in unusual eurrent.

* This was the single accurence in collections above Havana between 1920 and 1925: was taken in 1913-1915 as far north as Upper peoria Lake. 


\section{Some Principal Points Regarding Index Value}

Various extensive published lists, as well as questions frequently asked by workers newly interested. seem to imply, to say the least, an overconfidence in the simplicity and efficacy of the use of a few or many so-called index organisms in the determination of degrees of stream pollution. Less frequently are we asked to name those kinds, particularly of small bottom organisms, which are likely to be most useful for that purpose. This question of ten appears to be a definite reflection of the fact that various published lists, including our own, are much too long to be useful to the uninitiated worker without a good deal of explanation; as both it and other variations of inquiry seem to result from an impression that biological determinations of the extent of injury by sewage or other waste can be made by a more or less ruleof-thumb mechanical method, the practice of which calls for little by way of preliminary knowledge, except the names and identity of the species. As a matter of fact, the number of small botton-dwelling species of the fresh waters of our distribution area that can be safely regarded as having even a fairly dependable inclividual index value in the present connection is surprisingly small; and even those few have been found in Illinois to be reliable as index species only when used with the greatest caution, and when checking with other indicators.

The septic zone is, however, as compared with the pollutional and sub-pollutional zones next below it, much the more easily recognizable, whether by chemical determinations, by its physical appearance and its odors, or by a limited number of characteristic organisms ordinarily found in quite large numbers in various situations within it. But, as illustrating the lack of fixed rules even in this zone, the most abundant and characteristic plankton species of all the septic kinds taken in the upper Illinois River in 1911-1912. Sphacrotilus natans, was wholly absent from the middle and lower end of the Chicago Sanitary Canal, where examined the same seasons, although those waters were and are also septic. Again, Tubifer tubifex and other associated Tubificidac, commonly regarded as characteristic of the septic zone, were distinctly most abundant toward the lower rather than the upper end of the septic zone of the upper Illinois in 1911-1912; while in the lower end of the Sanitary Canal, also septic, they were wholly absent in all botton dredgings in those years.

The most serious limitations on the use of the members of the small botton animal population as indices in the pollutional zone, which is at the same time unusually difficult to recognize either from its physical or chemical features, have to do both with their frequently very confusing latitude of distribution and with the fact that so few of them occur in numbers large enough to encourage their individual use as indicators. As an actual example, it is found that out of a total of more than 27 kinds of miscellaneous small bottom animals taken in the pollutional zone between LaSalle and the foot of Upper Peoria Lake in the four 
years of collecting between 1920 and 1925 only two, that is. one tubificid worm (Limnodrilus hoffincistori) and a single larral chirononid ( $\mathrm{Ch}$ ronomus plumosus). could be said to have been generally connuon enough over wide ranges and to have fulfilled at the same time the other requirements necessary to encourage moderate conficlence in their value as indicators when taken by themselves. But of these at least one. the pollutional chironomid, Chironomus plumosus, has usually been classified heretofore as septic: as has apparently also been the case a good deal of the time with Limnodrilus hoffmcistiri, a species rery easily confused, in the absence of laborious micruscopic examination. With Tubife.t tubifcr. A second pollutional or unusually tolerant chirononid larra. Chironomus lobiferus, occasionally has occurred recently in ratber large numbers in the middle Illinois River, but at such widely separated points as to remove it from consideration as an important index species. The single remaining species, of the $2:$ kinds mentioned above, that has recently shown great abundance over wide territory, the small bivalve mollusk. Husculium transacrsum, in its turn, cannot be regarded as having any index value at all. Althotigh necessarily listed as an occasional pollutional species, because of its close association with Limmodrilus hoffmoisteri and Chironomus plumosus in pollutional muds above Peoria. it is correctly regarded merely as a case of unusual adaptability in a form that normally reaches quite as large numbers under clean-water conditions as those recently recorded by us in the pollutional territory of Peoria Lake and the neighboring parts of the Illinois River.

Still confining ourselves for illustration to the pollutional zone, and assuming that both Limmodrilus hoffmeisteri and Chironomus plumosus luave been recorded as present, we may inquire what standards. if any. are to be followed in striking the boundary line between numbers that are important and numbers that are best disregarcled. It is as well to say at once that the question cannot be answered: for the interpretation of degrees of abundance. both of individual species and of small groups of kinds with similar habit, is extremely likely to be a wholly relative matter. Thus, in 19:3-1925. we found the conmbined tubificid totals per square yard varying from under 1.000 to over 350,000 in the pollutional territory above Chillicothe at individual stations without having any ground for supposing conditions better at the one class of stations than the other. Likewise we have instances where Chironomus plumosus varied from near zero to more than one thousand per square yard in the same territory in the same season or between two seasons, without any evidence of clinge in sanitary condition appearing in the interval. Floods may carry away eggs or young midge larvae: severe winds may blow away swarms locally after emergence but before egg-laying; or bottom sampling may be done when the stages present are too small to be recognizable by the ordinary methods of recovery employed. On the other hand, inmmers, whether of worms or midge larvae, that may appear low in comparison with some of the lowest we have mentioned may be significant of serious change in sanitary 
condition when compared with average previous rates of occurrence of the same forms in the same area.

Individual species quite unusable alone for various reasons as index organisms frequently acquire a cumulative value for that purpose as they come to be grouped together, particularly when there are lists of former inhabitants of the same area under presumably cleaner-water conditions for comparison. Here lind is very likely to become more important than numbers, and a knowledge of the previous history of the same or similar areas nore important than any number of previously compiled lists of so-called key organisms graded according to index value. A good proportion of the conclusions presently drawn from the study of our recent Illinois River data are based upon this sort of grouping, as opposed to individual index value.

Not infrequently absence or much reduced numbers of formerly present clean-water species in an area may be quite as important or even more so than numbers of known pollutional forms found in determining degree of present or recent pollution. The pollutional forms themselves nay be largely excluded by the nature of the original bottom, as was recently the case in several short hard-bottomed reaches of the Illinois River only a short distance below the foot of Peoria Lake. Still again, there may be other special invisible excluding factors, as toxic factory wastes, operating against the successful entrance of pollutional species in normal numbers into a polluted area. And, as a concluding illustration, in essentially late sub-pollutional territory, the condition of the bottom may be fairly good over a large portion of the year, and the absence or scarcity of cleaner-water forms may indicate the periodic incursion of pollution with sudden or prolonged increase of water levels. When a good supply of pollutional forms are present, on the other hand, the fact of absence of formerly present clean-water kinds may have considerable value as an additional check. And in the absence of any knowledge of the previous history of the same area, lists of species from similarly conditioned and located umpolluted territory may serve, to some extent, the same purpose.

An almost inextricable confusion of all zones from septic to cleanvater is frequently met with in very shallow streams supplied with vegetation during the heated season, though scarcely less so than may sometimes occur very close to the margins of some large lakes and rivers. Herein lies the explanation of the comparatively rapid rate of selfpurification found by Weston and Turner* in the Coweeset River below Brochton, Mass.; and by ourselves in 1914 in the Fox River below Aurora and below Elgin, where the transition in mid-channel, in each case below a dam, from late septic or early pollutional to practically a cleanwater fauna was accomplished under midsummer low-water conditions in a distance of hardly more than 3 miles. In such very shallow areas

* Weston, Robert Spurr, and Turner, C. E. Studies on the digestion of a sewage filter effluent by a small and otherwise unpolluted stream. Contribution from San. Research Lab., Mass. Inst. Techn., vol. $X$, pp. 1-96; 1917. 
the rate of reaeration from the plants custonarily results in long continued supersaturation; and the various oxidizing and reducing processes, as well as the growth of the attendant organisms, are no doubt further accelerated both by the higher temperatures and the better access to light supplied.

Because of all of the various complexities above mentioned, and others, including those introduced by shifts from one to another distribution area, it can be seen that the individual student of the biological side of stream pollution in a new locality is lound sooner or later to be forced back upon his own resources to a large extent. He is very likely to find. in fact, that it is only after he has worked up his own species lists and arrived at his own conclusions as to index value and interpretations based upon it, whether as affecting indiviclual species or groups, that previously published clata from outside areas begin to fall into place and to serve a really practical use for final checking and comparison.

While certain strictures on the value of dissolved-oxygen readings: as indicators are made in this paper, there has been no intention unduly to minimize the value either of that or the other usual chemical inclices. The cases noted as calling for particular caution are those of las of the bottom condition behind that of the planliton and the oxygen supply. These are most frequent in streans where there is a sudden and marlied slowing up of current that continues long enough to perunit the rapid multiplication of chlorophyll-bearing plant and animal plankton, without allowing a permanent and parallel improvenent on the bottom in the same time over the same ground. Such instances aside, it must be said frankly that the simple procedure of listing side by side our recent dissolved-oxygen readings and the farthest upstream occurrences of out various Illinois River botton species from the unwidened Illinois River and Peoria Lake channel both above and below Peoria has served as one of the most important general sources of aid in getting order out of the chaos that seemed to reign in all directions when the unorganized clata were first spread out for study. Both for that and for other reasons the writer is strongly of the opinion that dissolved-oxygen deteminations should hold a fixed place as accessory routine in all biological studies of stream pollution.

If the problem set involves nice determination for the first time of the boundary lines between zones in the Kolkwitz-Mlarsson* schedule of self-purification, figures for free ammonia and nitrates, particularly if expressed as percentages of total nitrogen, also will be found of value. Because of the wide range of error due to the variable mortality of the less pollutional planliton organisms during the incubation period and to other interfering factors likely to enter at any point below the septic zone. the usefulness of bio-chenical oxygen-demand determinations is quite likely to prove doututul except as a test of the strength of raw sewage or relatively young effinents.

* For bibliographical references, sec p. $\$ 00$. 


\section{Changes in the Number of Species Taken and Missing}

Reduction in the total number of different kinds taken between I9I3I915 and 19?0.
Severe downward changes in the total number of kinds of small botton animals taken occurred in all sections of the river and Peoria

Lake between Chillicothe and Beardstown between 1913-1915 and 1920 . In the three subdivisions of Peoria Lake the reductions ran in all cases over 50 per cent: being 69 per cent in the Upper Lake, 22 per cent in the Middle Lake, and 50 per cent in the Lower. The largest percentage and absolute reduction of all, 83 per cent, occurred in the approximately $t 1$ miles between the foot of Peoria Lake and Havana, where the total number of kinds taken dropped from 91 to 15 in the five-year period. In the 31 miles between Havana and Beardstown there was a decrease in the same time of 48 per cent, or from 43 to 22 kinds.

The largest decrease quite naturally took place in the section of river between the foot of Peoria Lake and Havana, where both the total number of all kinds and the number of cleaner-water kinds had been highest five years previously. The percentage losses in Upper and Middle Peoria Lakes were also not much less ( 69 and 82 per cent) than between the foot of Peoria Lake and Havana, though the absolute losses were conspicuously less, because of previous contraction of the lists in response to mild pollutional conditions that prevailed before 1920 . The sizably smaller percentage loss in the Lower Lake (52 per cent) was no doubt in great part due to the much better protection afforded by the unusually rapid current that prevails over a large part of that area. The smallest loss of all, 48 per cent, in the section next below Havana, was probably due both to the tapering off of the pollution with distance and to the rather better average rate of current in a large portion of that section than in the 41-mile section just above.

Reasons why the reduction of the lists was not even more complete. particularly in the Peoria Lake region, and in the sections of river more immediately below Peoria, are to be found chiefly in the fact that in all of the subdivisions considered between Chillicothe and Beardstown a rather large but varying number of species were, even as early as 19131915, of such kinds as we might expect to show considerable tolerance. A table showing the total number of pollutional, ususually tolerant, and tolerant kinds contained in the 1913-1915 lists is given on page 419 . Those figures show that 38 to 51 per cent of the total number of species present in the three sections of Peoria Lake in 1913-1915 were assignable to either one or another of the pollutional, unusually tolerant, or tolerant groups; while in the section Wesley to Havana the percentage was 24 , and in Havana-Beardstown it was 32.

The increases in the total number of all kinds of small botton species taken in the various reaches between 1920 and 1925 were due principally to increases in the more tolerant kinds, and are discussed in the sections immediately following. 
TABLE IV

Total Neaber of Specifs Takex, Fxclusive of Euge Forms axd Tilose ProTECTEI BY UNTSEAL CITRENT

\begin{tabular}{|c|c|c|c|c|c|}
\hline Reaches & $1913-1915$ & 1920 & $\left|\begin{array}{c}\text { Per cent } \\
\text { decrease } \\
1915 \text { to } \\
1920\end{array}\right|$ & 1924 & 1925 \\
\hline Upper Peoria Lake........... & 33 & 10 & 69 & is & 17 \\
\hline Middle Peoria Lake........... & 36 & 10 & $i 2$ & 34 & 33 \\
\hline Lower Peoria Lake............ & 44 & 22 & 50 & 25 & 26 \\
\hline Foot of Peoria Lake to Havana & 91 & 15 & 83 & 21 & $2 S$ \\
\hline Havana to Beardstown........ & 43 & 22 & 18 & 16 & 27 \\
\hline
\end{tabular}

Reduction of the mumber of clcanacater specics taken betacen 19131915 and IQ20; and sloat rate of replaccuent since $19 \geq 0$. sanitary condition that has taken place since, are the changes in the numnber of clean-water kinds of small botton animals taken in the various sections of the river between 1913-1!15 ancl 1925. The figures used in these comparisons are in all cases the numbers left after deduction of species fonnd only at the edges or in unusual current. Summarized, these show: in Upper Penria Lake a decrease from 11 clean-water linds to none at all between 1!13-1!15 and 1!200: in Nidalle Peoria Lake a decrease from 18 in $1913-1915$ to none in $1 ! ?$ ? $)$; in the Lower Lake a drop from 1.; in 1913-191.j to none in 1920 ; in the 10 miles from Wesles to Havana a drop) from 49 to $3:$ and in the 31 miles from Havana to Beardstown a drop from 1 ? in $1913-1915$ to only 6 in 1920 .

The very slow rate of replacenent of clean-water species between $19 ? 0$ and 199.5 was nost noticeable in Lpper and Lower Peoria Lakes. where the number taken, after edge-iorms are deducted, remained at zero throughout the four collecting years $1929-1925$, with the single exception of one occurrence in the open water of Lower Peoria Lake in 192. In the Niddle Lake the number of clean-water species taken in open water remained at zero through 19.9 .9 . but stood at $3 \mathrm{in} 1923$ and rose to and remained at is through $192 \mathrm{t}$ and 1925 . These were ail isolated occurrences, in very small numbers, nsually only a single specimen or two in a haul: and they may quite possibly mark the location of scattered springs under the lake bed, such as are known to occur in the lower part of the Upper lake where several species of Unionidac were found mexpectedly surviving in 1921 and 1925.

* See p. 439 and reference mentioned in footnote on same page. 
In the combined stretches of river between Peoria and Havana the number of clean-water kinds of snnall botton animals taken varied rather widely between 1920 and 1925 , but ended in 1925 with only 4 as compared with 3 in 1920 and 49 in 1913-1915. In the section between Havana and Beardstown, rather similarly, the number of cleanwater kinds taken actually dropped between 1920 and 1924 , and had risen only negligibly in 1925 as compared with 1920 . It is of course to be kept in mind that the persistence of a small number of linds is not so conclusive of continuing unchanged pollution, as the sharp reductions between 1913-1915 and 1920 were of its incidence; since it is quite within the possibilities for improvement to occur (as we think it has since 1923 below Copperas Creck Dam) at a visibly more rapid rate than the locally exterminated species are able by natural nueans to reestablish themselves.

\section{TABLE V}

Number of Clean-Water Species Taken, Exclusive of Enge-forms and Tilose Protected by Unusual Current

\begin{tabular}{|c|c|c|c|c|c|c|c|c|}
\hline Reaches & $\begin{array}{c}\text { Total of } \\
\text { all kinds } \\
\text { taken } \\
1913-1915 \\
\text { for com- } \\
\text { parison }\end{array}$ & $\begin{array}{l}1913- \\
1915\end{array}$ & $\begin{array}{c}\text { Per } \\
\text { cent } \\
\text { of } \\
1913- \\
1915 \\
\text { total }\end{array}$ & 1920 & 1922 & 1923 & 1924 & 1925 \\
\hline Upper Peoria Lake..... & 33 & 11 & 39 & 0 & 0 & 0 & 0 & 0 \\
\hline Middle Peoria Lake.... & 36 & 18 & 50 & 0 & 0 & 3 & 5 & 5 \\
\hline Lower Peoria Lake.... & 44 & 15 & 34 & 0 & 1 & 0 & 0 & 0 \\
\hline $\begin{array}{c}\text { Foot of Peoria Lake to } \\
\text { Havana } \ldots \ldots \ldots \ldots \ldots\end{array}$ & 91 & 49 & .58 & 3 & $\begin{array}{l}\text { no } \\
\text { collect- } \\
\text { ions }\end{array}$ & 8 & 0 & 4 \\
\hline Havana to Beardstown. & 43 & 17 & 39 & 6 & $\begin{array}{l}\text { no } \\
\text { collect- } \\
\text { ions }\end{array}$ & 3 & 2 & 7 \\
\hline
\end{tabular}

The species from the $1913-1915$ lists missing 1920 to 1925 .
In all three sections of Peoria Lake and in the forty odd miles between Peoria and Havana the number of kinds of small bottom aninals from the 1913-1915 lists that had shifted to the nissing colunn by the summer of 1920 ran from nearly threefourths to more than seven-eighths, in individual reaches, of the original 1913-1915 totals. The actual number of kinds missing and the percentage in each case was: Upper Peoria Lake, 26 missing. or is per cent; Middle Peoria Lake, 32 missing, or 38 per cent; Lower Lake, 32 missing, or 72 per cent; Wesley-Havana, is missing, or 85 per cent. The close agreement of the percentages missing in Peoria Lake and in the first forty odd miles below, in 1920 apparently results from the fact that in the 
three subdirisions of the Lake. where there were already in 1913 1915 relatively large numbers of tolerant or unusually tolerant kinds. the wave of pollution originating at Chicago was heaviest; while in the first 40 miles below Peoria. where the combined Chicago and Peoria load was probably on the average somewhere near the same, there was a visibly larger percentage of clean-water and less tolerant kinds.

The smallest of all the missing lists. that in the 30 miles between Harana and Beardstown, which stood at ?: in $192(0$. representing a loss of ri2 per cent from the 1!13-1915 total, was itself far from small. The moderately better showing made there in 1920 than in the sections of river immediately northward was of course largely a matter of the greater distance from the sources of pollution upstream.

The rate of replacement of missing species between 1920 and 1925 was fairly uniform over the three sections of Peoria Lake. and was more rapid in all three of them than in the next 00 miles of river below Peoria. Thus, the portion of the 1913-1915 lists missing dropped in the three subdivisions (Lpper. Middle, and Lower Peoria Lake) from is per cent, so per cent. and i: per cent to 5 i per cent, 63 per cent. and 63 per cent. in order downstream. In rather sharp contrast, in the 40 miles between Peoria and Havana. the percentage nussing dropped between $19: 00$ and 19.5 only from s.j per cent to $: 9$ per cent. The difference in rate of replacement between this section of the river and Peoria Lake is clearly a consequence of the larger proportion of relatively sensitive species and the smaller percentage of unusually tolerant kinds found here in recent years, together with the naturally slower rate of reestablishment of the more sensitive forms. In the lowermost section of the river studied 19.20 to 19.5. Havana to Beardstown. as in the reach Peoria-Havana, and apparently in large part for similar reasons, the size of the missing list changed hardly noticeably during the five-year period. the percentage of the 1913-1!15 list missing standing at is in 1925 as compared with 62 in 1920 .

T.ABLE VI

TOTAL NI MHER OF SPECIES FROM 1913-1915 LISTS MISAING

\begin{tabular}{|c|c|c|c|c|c|c|}
\hline Reaches & $\begin{array}{c}\text { Total of } \\
\text { all kinds } \\
\text { taken } \\
1913-1915 \\
\text { for com- } \\
\text { parison }\end{array}$ & $\begin{array}{c}1920 \\
\text { missing }\end{array}$ & $\begin{array}{c}\text { Per cent } \\
\text { of } \\
1913-1915 \\
\text { total }\end{array}$ & $\begin{array}{c}1924 \\
\text { missing }\end{array}$ & $\begin{array}{c}1925 \\
\text { missing }\end{array}$ & $\begin{array}{c}\text { Per cent } \\
\text { of } \\
1913-1915 \\
\text { totat }\end{array}$ \\
\hline Upper Peoria Lake... & 33 & 26 & 38 & 21 & 19 & $5 \%$ \\
\hline Middle Peoria Lake.. & 36 & 32 & BS & 20 & 23 & 63 \\
\hline Lower Peoria Lake... & 44 & 32 & 12 & 30 & $2 \mathrm{~S}$ & 63 \\
\hline Foot of Peoria Lake to & & & & & & \\
\hline Havana ............ & 91 & is & 85 & 76 & 72 & $\gamma 9$ \\
\hline Havana to Beardstown & 43 & 27 & $6 ?$ & $2 S$ & 25 & 58 \\
\hline
\end{tabular}


When we add together, for

The changes in the total number of pollutional, unusually tolcrant, and tolcrant kinds taken. each section of the river and Peoria Lake studied, the pollutional, unusually tolerant, and tolerant kinds of small bottom animals taken in the 1913-1915 period of relatively clean water and compare with the totals of the same groups for 1920, immediately following the severe wave of pollution that destroyed most of the cleaner-water species, it is surprising at first to note that with but one short reach (Lower Peoria Lake) excepted, these numbers decreased also, rather than increased, as the cleanwater species declined. Thus the total of pollutional, unustally tolerant, and tolerant kinds fell from 17 to 10 in the Upper Lake between 19131915 and 1920 ; from 15 to 10 in the Middle Lake; from 22 to 12 in the section between Wesley and Havana; and from 14 to 10 in the section between Havana and Beardstown. The only increase occurred in Lower Peoria Lake, where the total of pollutional, unusually tolerant, and tolerant kinds rose from 17 to $\approx 0$ between $1913-1915$ and 1920 .

Next we notice that between 1920 and 1922 , as conditions on the bottom became slightly, but only slightly, better, the total of pollutional, unusually tolerant, and tolerant species rose sharply in the two upper sections of Peoria Lake, and moderately ( 20 per cent) in Lower Peoria Lake. These increases were added to in all three sections of Peoria Lake between 1922 and 1923; and the change between 1923 and 1925 left the figures either larger or negligibly less than in 1922 . In the river between Peoria and Havana also the total number of pollutional, unusually tolerant, and tolerant kinds nearly doubled between 1920 and 1923, dropped back again close to the 1920 figure in the severe flood summer of 1924, but rose again to the 1923 figure in 1925. In the section between Havana and Beardstown there was the least increase between 1920 and 1923 (only 10 per cent), but after remaining unchanged through the severe flood of 1924, it nearly doubled in 1925 .

The first reason to be noted in explanation of these changes is that neither the various sections of Peoria Lake nor the sections of the river proper studied between Peoria and Beardstown were even approximately clean five to seven years before 1920 , though the latter two sections or at least the last one were relatively much more so than the lake. Second to be noted is that not merely the unusually tolerant and less tolerant species of our presently adopted classification, but also most of the pollutional species have an exceedingly wide range of distribution, which normally carries them, at least in moderate or small numbers, into relatively clean-water territory. In other words, the pollutional, unusually tolerant, and tolerant species were already there in 1913-1915, to decrease or increase as conditions might warrant. So, in the Upper Lake the combined number of pollutional, unusually tolerant, and tolerant kinds made up 51 per cent of the total of all kinds; in Middle Peoria Lake it made up 41 per cent; in the Lower Lake 38 per cent; and even 
Bottoy FatA, Illixols RIVR, 1913-1925

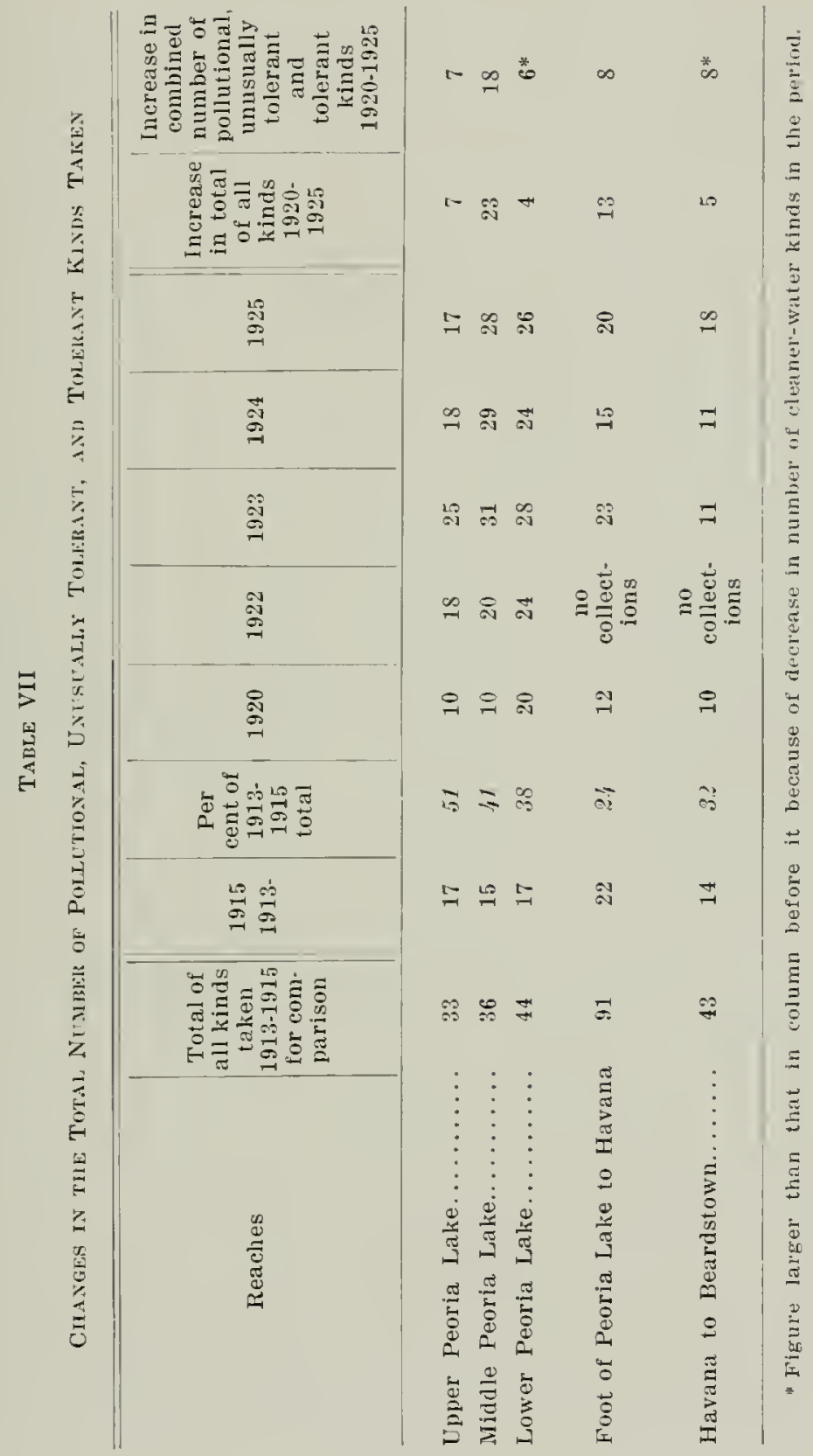


in the reaches between Peoria and Havana and Havana and Beardstown. it made up $2 t$ and 32 per cent of the totals of all kinds taken.

The noticeable decreases in the total number of pollutional, unusually tolerant, and tolerant kinds of small bottom animals recorded as pollution increased between 1913-1915 and 1920 in all sections of the river here compared were naturally greatest in the two last-named groups of the three. The very marked rise in the abundance of the Tubificidae in Upper Peoria Lake after 1920, as the condition of the bottonl muds renained substantially unchanged or improved but slightly, however, suggests that even some of the pollutional hinds may at times be subjected to periods of low oxygen that are longer and more severe than they are equipped to stand.

The good increases in totals of pollutional, unusually tolerant, and tolerant kinds between 1920 and 192.5 are believed to suggest improvement in the condition of the bottom muds as compared with conditions at a hypothetical apex of pollution shortly before 1920 rather than in that year. And the relatively slight improvenent on the bottom indicated by the failure of the cleaner-water kinds of small bottom animals to increase and of the supply of bottom dissolved oxygen to improve above Copperas Creek Dam since 1920 is further confirmed by the fact that in all reaches above Beardstown the increase in the total number of kinds of small bottom animals taken was almost equalled or exceeded during the same five years by the increase in the combined number of pollutional, unusually tolerant, and less tolerant kinds. The cases (of Lower Peoria Lake and Havana-Beardstown) where the increase in pollutional, unusually tolerant, and tolerant kinds exceeded the increase in all kinds in the five years following 1920 result from the actual decrease in the total number of clean-water kinds taken in those two reaches during the period.

\section{Changes in the Dissolved Oxygen Supply}

Sharp decreases in the surface dissole'ed o.rygen in mid-channel betreen Chillicothe and Bcardstown betaech I9II-I9I2 and I920.
In July-September, 1911 and 1912 , the nearest years to $1913-$ 1915 for which we have records, the dissolved-oxygen supply at all points between Chillicothe and Beardstown, as measured by surface figures in micl-channel, ruled moderately to well above the usually accepted minimum point for most of our fishes (or above 2.50 parts per million). Between 1911-1912 and 1920, the largest decline occurred at Chillicothe, where average figures of $3 . \% 2$ and 3.0 parts per million in July-September, 1911-1912, gave way to an average of only $0.4 \tau$ parts per million for four readings taken July-September, 1920. The readings obtained in the three sections of Peoria Lake in the summer of 1912 are so scanty, and so irregular (due probably to the coincidence of some of them with rich and some of them with poor phytoplankton periods) that they are of almost no value for comparison and are best here omitted. Dropping only ten miles below 
Peoria to Pekin, the downward trend was clearly resumed, the decline there between July, 191\%, and July-September, 19:11, having been ?.t parts per million, or from 5.1 to 3.0 parts per million. Above the Copperas Creek Dam the comparison between July, 1!1:, and July-September, 1!20. was even more sharp, the figures dropping from t.0 to 1.2 .5 parts per million. At Havana there was a slump from 3.6is parts per million in July, 1912, to 2.25 in July. September, 1920 : and at Beardstown from $t .8$ to $? .35$.

TALIF: VIII

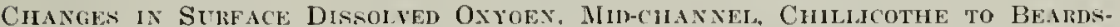
TOWx. 1911-1912 TO 1920: l’AKT PEK MlLION*

\begin{tabular}{|c|c|c|c|}
\hline Sampling stations & $\begin{array}{c}1911 \\
\text { July-Sept. }\end{array}$ & $\begin{array}{l}1912 \\
\text { July }\end{array}$ & $\begin{array}{c}1920 \\
\text { July-Sept. }\end{array}$ \\
\hline Chillicothe & $3.72^{8}$ & 3.0 & $0.47^{4}$ \\
\hline $\left.\begin{array}{l}\text { Upper Peoria Lake } \\
\text { Middle Peoria Lake } \\
\text { Lower Peoria Lake }\end{array}\right\}$ & $\ldots \ldots$ & ee tex & - \\
\hline Pekin ........................ & $\ldots$ & 5.4 & $3.0^{3}$ \\
\hline Above Copperas Creek Dam............ & $\ldots$ & 4.0 & $1.25^{2}$ \\
\hline Havana $\ldots \ldots \ldots \ldots \ldots \ldots \ldots \ldots$ & $\ldots$ & $3.65^{2}$ & $2.25^{3}$ \\
\hline Beardstown $\ldots \ldots \ldots \ldots \ldots \ldots \ldots$ & $\ldots$ & 4.8 & 2.35 \\
\hline
\end{tabular}

* Exponent is number of readings averaged.

$\dagger$ Watel" levels, all yeal's, about nommil fol season.

Slight or imporceptible increases in bottom dissolied oryegn figures in Upper and Middle Peoria Lake channel since 1020 . the botton muds between Chillicothe and the foot of the Middle Lake between $19: 0$ and $19 \cdot \%$. If recent estimates* of increase in the population of the city of Chicago between 1920 and $192: 2$ are at all to be relied upon, however, the persistence of low dissolved oxygen figures in this portion of the channel, in spite of recent enlargenent of the fraction of the total population taken care of by the new sewage-treatment plants. can hardly be regarded as sur]urising.

For the purpose of the present comparisons we have taken a selecfion of the nichenamel stations covered in the summer work of $1 ! 90$. 19.23 , and 19.95 ; leaving out $192+$ because of the abnomal diluting effect of the continuous summer-flood of that year. Taking Chillicothe and Rome as representing Upper P'eoria lake and vicinity. it is true that average bottom readings for the summer months showed a very slight rise at both stations between 19200 and 19.25 ; from 0.2 to 0.53 parts per million at Chillicothe, and from 0.2 to $0.6 \mathrm{f}$ parts per million at Rome, to be particular. But when we examine the individual readings for $19: 0$ and 1925 for the number of low points, we find at Chillicothe in 1920 one

\footnotetext{
* See 1). $: 99$.
} 
reading under 0.3 parts per million out of a total of three; while in 1925 at the same station and approximately the same dates there were seven readings under 0.3 parts per million out of a total of twelve. At Rome the comparison was not quite so good, but there were two readings there under 0.3 parts per million out of a total of nine in the summer of 1925 (one of 0.2 and another of 0.1 parts per million), compared with one out of two at Rome in 1920.

In the upper part of the Middle Lake, represented by Mossville, the average of nine readings June-September, 1925, was not far from one point lower than the average of five readings at Mossville in JulyAugust in 1920, the exact average figures being 1.98 and $1.0 \%$ parts per million. respectively. In the lower part of the Middle Lake, represented by A1 Fresco Park, the dissolved oxygen supply is subject normally throughout the summer months to great variations, due to rapid and extensive changes in the amount of phytoplankton present. But even here, the average of six mid-channel readings taken in the summer of 1925 (3.06 parts per million) was hardly visibly larger than the average of seven samples (3.01 parts per million) taken in approximately the same season in 1920 . When we take into account the frequency of low readings, we find at Mossville only two readings under two parts per million out of a total of five in mid-channel in July-August, 1920, compared with seven under 2 parts per million out of a total of nine in 1925 . At Al Fresco Park the number of readings in July-August, 1920, under 2.5 parts per million was three out of a total of seven samples taken in mid-channel; and in 1925. July-September, three out of a total of six.

TABLE IX

Chaxges in Botton Dissolyed Oxygen, Mid-channel, Chillicothe to near Foot

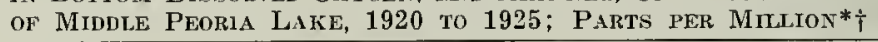

\begin{tabular}{l|l|l|l}
\hline \hline & 1920 & 1923 & 1925 \\
\hline
\end{tabular}

Upper Peoria Lake or

vicinity:

Chillicothe $\ldots \ldots \ldots 0.2^{3}$ (July-Aug.)

Rome $\ldots \ldots \ldots \ldots \ldots, 0.2^{2 \text { (July-Aug.) }}$

$0.15^{4}$ (June-Aug.)

$0.44^{5 \text { (June-Aug.) }}$

$0.53^{12 \text { (June-Sert.) }}$

$0.67^{9}$ (June-Sept.)

Middle Peoria Lake:

Mossville $\ldots \ldots \ldots \ldots \quad 1.98^{5}$ (July-Aug.)

Al Fresco Park.... $3.01^{7}$ (July-Aug.)
$1.73^{6}$ (June-Aug.)

$4.80^{2}$ (June-July.)
$1.07^{9}$ (June-Sept.) $3.06^{6}$ (July-Sept.)

* Exponent is number of readings averaged taken in the months indicated. $\dagger$ Water levels, all years, about normal for season.

Visible increases in the bottom dissolz'ed oxygen in mid-channel between Copperas Creck Dam and Beardstoren after 1923.

since 1920 have generally been quite irregular and are best left out of the

In Lower Peoria Lake and in the river between Wesley (opposite South Peoria) and points shortly above Copperas Creek Dam the midsummer dissolved oxygen readings 
discussion at present. The first low, then high figures encountered, at various stations in this section of the river, sonetimes reversed on the next round, are a consequence of the always varying mixture of fresh sewage received at Peoria and Pekin with more or less highly oxygenated water received from the frequently rich plankton-bearing wide-waters of the middle and lower sections of Peoria Lake. Omitting these figures. and dropping abont 31 miles below the foot of Peoria Lake, to Liverpool. we find again for the fll-mile section of river between Liverpool and Beardstown readings that are as a rule much more regular and certain in significance, but have relatively fewer of them for the summer months since and including 1!?0, than were taken in Peoria Lake. Taking Liverpool, Havana. and Beardstown, 31, 40, and i1 miles below the foot of Peoria Lalie, approximately, as representative stations for this section, we note little change npward, or actual decrease in the anounts of bottom oxygen present betwcen 1920 and 1923 : averages or single samples taken at the three stations in July-September of those two years rmning: Liverpool $1.75^{2}$ in $1920^{*}$ and $0.0^{1}$ parts per million in 19.23 : Havana $2.16^{3}$ parts per million in 19:0, and $1.1^{1}$ in 19233 ; and Beardstown ?.?' in 1920 and 2. $t^{1}$ in 1923.

Between 1923 and 1925, however, an emphatic upturn in the botton dissolved oxygen is indicated by our rather linited number of mid-channel readings from these same three stations. The comparisons with 1920 stood: Liverpool, increase from $1.25^{2}$ to $4.45^{2}$ parts per million: Havana from $2.16^{3}$ to $4.60^{2}$ parts per million; and Beardstown from $2.2^{1}$ to $3.3^{1}$ parts per unillion. It appears likely, though not wholly certain, that the increases at Liverpool and Havana between 1993 and 1925 reflect inprovement in methods of waste-disposal recently put into operation by the Corn Products Refining Company at Pelin: and that the moderate relapse in the dissolved oxygen figures at some stations below Harana in the sumnuer of 1923, as in other recent years, is a consecuence of delayed termentation of some of the carbolychate wastes still received at Pelin or Peoria.

TABLE X.

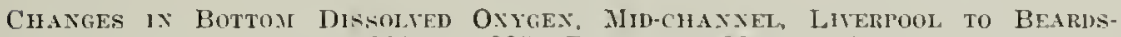
TOWx. 1920 TO 1925 ; PARTS PER MHLION*

\begin{tabular}{|c|c|c|c|}
\hline Sampling stations & 1920 & 1923 & 1925 \\
\hline $\begin{array}{l}\text { Liverpool } \ldots \ldots \ldots \ldots \ldots \\
\text { Havana } \ldots \ldots \ldots \ldots \ldots \\
\text { Beardstown } \ldots \ldots \ldots \ldots \ldots\end{array}$ & $\begin{array}{l}1.75^{-1} \text { (Aug...iept.) } \\
2.16^{3 \text { (duly-Nept.) }} \\
2.2^{1 \text { (Neyt.) }}\end{array}$ & $\begin{array}{l}0.0^{1} \text { (Aug.) } \\
1.1^{1 \text { (July) }} \\
2.4^{1 \text { (Aug) }}\end{array}$ & $\begin{array}{l}4.45^{2} \text { (July) } \\
4.6^{2} \text { (July) } \\
3.3^{1 \text { (July) }}\end{array}$ \\
\hline
\end{tabular}

* Exponent is number of readings averaged.

$\dagger$ Water levels, all years, about normal for season. 
Uncertain index value of dissolicd orygen figures from the Peoria Lake zide-zeaters since 1920 .
In the sumner months of 1920 and succeeding years dissolved oxygen readings from the wide-waters of Upper and Mid-

dle Peoria Lake have agreed mainly in the single point of showing great irregularity. This is, however, not wholly unexpected, as both these sections of expanded river lie in close proxinnity to the boundary line between the light and the heavy oxygen-producing plankton of the warm low-water period (in other words, the blue-green Algae and the chlorophyll-bearing Algae and Flagellata). The location of this line in 1920 and 1922 varied sometimes as much as the length of either lake in a few days or weeks, as there occurred shifts in water levels, temperature, wind, and sunlight. Under the most favorable conditions for the multiplication of the Chlorophyceae and the green Flagellata, we occasionally obtained in 1920, even in the wide-waters of the Upper Lake, surface readings of dissolved oxygen topping 6 or 5 parts per million. A few days or weeks later, as the lower limit of the largety colorless or blue-green plankton moved several miles further downstream, it was not unusual to get bottom readings uncler one part per million more than three-quarters of a mile from midchannel in the Upper Lake; and readings under two parts per million at similar distances even in the lower part of the Middle Lake.

Because of this unusually great variability in dissolved oxygen figures, the minimum mid-summer readings are believed to be of more value than averages in estimating the fundannental or underlying sanitary condition in the Peoria Lake wide-waters. A short table of minimum dissolved oxygen readings taken at long distances from the mid-channel line in the Upper and Middle Lakes is shown on p. 425. For comparison with the location of these minimum readings, the approximate full recent low-water widths of the lake on the side beyond the nid-channel line from which they were taken are also given. These show that at times both in the summer of 1920 and 1922 comparatively low bottom dissolved oxygen was not infrequent at stations well toward the margins of the east widewaters of these two subdivisions of Peoria Lake.

The 1924 figures are of no value for comparison because of excessive dilution due to flood conditions all summer. The 1925 unpublished figures by the State Water Survey are apparently deficient in readings from stations at long distances from the center of the channel, in all sections of Peoria Lake. Although this is the case, it is believed it may safely be assumed that, as there was practically no change in the channel supply of bottom oxygen in the Upper and Niddle Lakes between 1920 and 1925 , so there cannot have been any appreciable amount of change of a permanent nature in the wide-waters, at least where open and comparatively free from vegetation.

During the summer season, our recent records of dissolved oxygen, both surface and bottom, in the east wide-waters of Lower Peoria Lake have in general been more consistently high in comparison with the indications supplied by the bottom fauna than in either the Upper or Middle 
Lake. But this advantage is probably largely nullified at other seasons, as in the late autumn. when the first northwest winds carry over local pollution from the Peoria water front. Effects of this wind- and wave-borne pollution are apparent, in fact. on comparison of the number of small bottom animals with lowest tolerance taken in recent years in the Middle and Iower Jake. It is found, in brief, that if a few species that have sturvived in the Lower Lake since 1920 by virtue of unusual current of the very wide channel be excepted, the Middle Lake has recently yielded a larger number of small bottom species with low tolerance than has the Lower.

TABLE XI.

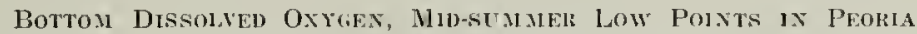
LAKE WHE-WATELS, 1920 AN1) 1922.*

\begin{tabular}{|c|c|c|c|c|c|}
\hline Reaches and stations & Year & $\begin{array}{l}\text { Approximate } \\
\text { full width } \\
\text { of lake } \\
\text { east of } \\
\text { mid-channel } \\
\text { line at recent } \\
\text { summer low } \\
\text { water levels }\end{array}$ & $\begin{array}{l}\text { Distance } \\
\text { east of mid- } \\
\text { channel line } \\
\text { of low bottom } \\
\text { dissolved } \\
\text { oxygen } \\
\text { readings }\end{array}$ & \multicolumn{2}{|c|}{$\begin{array}{l}\text { Low rearlings } \\
\text { of bottom } \\
\text { dissolved } \\
\text { oxygen } \\
\text { p. p. m. }\end{array}$} \\
\hline \multicolumn{6}{|l|}{ Upper Peoria Lake } \\
\hline Rome ............ & 1920 & 0.87 & 0.75 & 1.5 & July \\
\hline Rome ........... & 1920 & 0.87 & 0.62 & 2.0 & Aug. \\
\hline Rome .......... & 1922 & 0.87 & 0.70 & 1.0 & Aug. \\
\hline Rome, 21/2 mi. below & 1920 & 0.87 & 0.62 & 2.7 & July \\
\hline lRome, $2 \frac{1 / 2}{m i}$. below & 1920 & 0.87 & 0.83 & 0.4 & Aug. \\
\hline \multicolumn{6}{|l|}{ Middle Peoria Lake } \\
\hline Mossville $\quad . . \ldots \ldots$ & $1: 422$ & 0.87 & 0.60 & 3.0 & Aug. \\
\hline Mossville $\ldots . . . \ldots \ldots$ & 1920 & 0.87 & $0.75+$ & $3.1-3.4$ & July \\
\hline Mossville, $3 / 4$ mi. below & 1920 & 1.00 & 0.62 & 2.0 & Aug. \\
\hline Al Fresco ......... & 1920 & 0.75 & 0.50 & 1.9 & Ang. \\
\hline
\end{tabular}

\section{Major Changes in Abundance of the More Important Groups}

Decreases in all important groups crect Tubificidae and Chironomidae between 1915 and 1920.
On the loasis of average numbers of individuals jer square yard, all of the more inportant groulss of the small bottom animals except two are shown to have suffered large decreases in all reaches of the river and l'eoria Lake between Chillicothe and Beardstown in the period between 1913-1915 and 1930 . The most important declining groups, in point of both numbers and bulk previous to 1920 , were the Gastropoda. Sphacridac (represented frincipally by a single species), and Ephimoridac (also represented almost wholly by a single 
species). All of the non-current-loving Gastropoda except one (Campeloma subsolidum) have been proved by their later records of extremely slow replacement to belong among the more sensitive of the small bottom species: and the same is true of the single important burrowing mayfly nymph of the middle Illinois River (Hcragcnia bilincata). The most important of the several kinds of Sphacridac (Musculium transvcrsum). on the other hand, has since 1920 shown itself, by its rapid recovery to and above 1913-1915 figures in the worst polluted parts of the Peoria Lake channel and points above, to be unuswally tolerant; and stands as one of our best items of biological evidence that at some time between* 1915 and 1920 conditions on the bottom in those portions of the Illinois River were even worse than we found them in the last-named year.

The declines in Gastropoda and Sphacriidac between 1913-1915 and 1920 were heaviest in the previously very rich section of river which extends some nine or ten miles above the Spoon River bar at Havana. Here the drop in average numbers of Sphacriidac between 1915 and 1920 was from 1,709 to only 46 per square yard when all areas are combined; and the average decline in total Gastropoda was from 496 to only 20 . In the three sections of Peoria Lake the declines in both of these groups in the same period were also very marked, but were actually small enough, in part as a consequence of previous damage suffered, so that they were largely or wholly made up in 1920 by the simultaneous increase of the pollutional worms and midge larvae.

Other minor groups, in addition to the burrowing May-flies, that showed sharp declines in some or all reaches between 1915 and 1920 included the leeches, the caddis-flies (Hydropsychidac), the Odonata, Planaria, and Amplipoda, to name only the more important entries in a much larger list. Of these the leeches, the Odonata, the Planaria, and Amphipoda had enjoyed a wide distribution, in all reaches. (with the exception of the last two, usually in moderate numbers) previous to 1920 . The Hydropsychidac had been confined principally to those sections of the river with hardest bottom and swiftest current in the 1913-1915 period.

Increases in Tubificidac and Chironomidae 1915 to 1920 .

The two groups of small bottom animals that showed large increases in numbers in all sections of the river between Upper Peoria Lake and Beardstown as pollution became heavier between 1915 and 1920 were the Tubificidac and the Chironomidac. Both septic and pollutional Tubificidac of at least two genera and several species, including Tubifc.r tubif ex and several species of Limmodrilus, always had been represented under the cleaner-water conditions of 1913-1915 and earlier, at least in moderate numbers in the nuddier sections of the middle and lower Illinois River; though they then attained large numbers in the sections of river here considered only in restricted localities subject to constant or occasional local pollution. The Chironomidae before 1920 included more than a dozen species, several of which have since turned

\footnotetext{
* See p. 439 and reference mentioned in footnote on same page.
} 
out to be of mustually tolerant habit; and two or three which seem easily to stand pollutional conditions. Ilost important among the latter are: a variety of Chironomus phmosus, with rentral blood gills of adaptable length for living under high or low oxygen concentration: Chironomus lobiferus; and a small form much like Chironomus plumosus that has been recorded from Illinois previously as Chironomus decoris.

The increases in both the Tubificidac and the Chironomidac between 191.5 and 19:0 were greatest in the three sections of Peoria Lake and in the formerly rich gastropod territory lying in the first ten miles abore Havana: these comprising the principal reaches with practically continuous soft black-silt botton originally best adapted as habitats for these two groups as represented. The extreme average increase in Tubificidac in numbers (in Upper Peoria Lake) was from 16 to ?.t6i3 per square yard between 1915 and 1920: and in Chironomidac, in the same lake from 10 per square yard to $: 33$.

Below Peoria, the Tubificidac at $t 6$ per square yard, were about 30 times as numerous in the section between Liverpool and Harana as they were in the same area in 1915. Such an increase, however. is relatively: small as compared with the more than 150-fold increase in Tubificidar in the same time in Cpper Peoria Lake. In strong contrast with the relatively much greater increase of Tubificidac than of Chromomidue in the Lpper Lake between 1915 and 1930 . in the formerly rich sastropod territory just above Havana the rate of increase of the Chironomidae in the five years greatly exceeded that of the Tubificidac. Here the Chironomidac were multiplied more than 190 -iold between 1915 and 1990 , as compared with 30 times for the Tubificidac.

Continued increase of the Tubificidac and Sphacriidac since 1920 , and increase of leches after I024.

Peoria Lake. These gains were held, up to $19 \% 3$, in both places. and between 1929 and 19.35 were extended in these or other reaches to still larger figures for both groups. Comparing the $19 \% 4$ or $19 \% 5$ figures with those of $19: 0$ (or 1915) the most striking increases took place in Lpper Peoria Lake. where these woms rose from ?.46:3 to $39.18 \%$ per square yard in fou or five years; in the Lower Lake, where the rise was from is to 6,919 per square yard: and in the section of the river from the Peoria and Pekin Union Railway bridge to Pekin, where there was an increase from none in 191.j ( 110 "collections in $19 ?(1)$ to 19.019 in $19 \cdot 25$. Increases in the Tubificidac in the Liverpool-to-Havana and the Havanato-Beardstown sections between 1920 and 1925 were less, but in both of these sections the figures moved up from under 50 to around $?, 000$ per square yard.

The increases in the Splacridac from 1920 to 192.5 were nore irregular than in the Tubificidac, very possibly in part because this group is a 
preferred fish food to a much greater extent than the worms. Quite consistently, also, the Sphacriidac reached their greatest numbers in or near two of the best conmercial fishing reaches (Upper Peoria Lake and Liverpool to Havana) in the continuous stmmer flood year 1924 (instead of 1925), when large numbers of the fishes were probably feeding in the "brush". In Upper Peoria Lake average numbers in all areas combined rose from $5 \%$ per square yard in 1920 to $18,11 t$ in 1924 ; in the Middle Lake, from $3 \mathrm{in} 1920$ to 4.497 in 1925 ; and in the Lower Lake from 1.5 in 1920 to 1122 in 1925 . Just above Havana the gains approached those in Upper Peoria Lake-swinging from 46 per square yard in 1920 to 12.785 in 1924. Between Havana and Beardstown, in an always less favorable, because harder, bottom, the rise was only from $\gamma$ to $11 \dot{2}$ up to 1924 , and to 2.561 in 1925 .

The leeches, after declining in numbers only moderately, from 1915 to 1920 , as practically all the Illinois River species are of unusually tolerant or even occasionally pollutional habit, rose hardly appreciably till 1924 or after. The largest part of their increase came between 1924 and 1925 and was most conspicuous in three short reaches: in Middle Peoria Lake. where they rose from none in 1920 to 548 per square yard in 1925 ; in the section between the foot of Peoria Lake and Pekin, where they rose from 58 in 1915 (no collections in 1920 ) to 1,511 in 1925 ; and in the ten miles immediately above Havana, where they increased from under 20 per square yard to more than 10,000 per square yard between 1920 and 1925 . Below Havana increases were negligible in the five years following 1920.

The marked increases, rather than decreases, noted in the total Tubificidac between 1920 and 1925 are in apparently significant agreement with the botton dissolved-oxygen figures from the channel above Peoria in indicating little or no change in sanitary condition in the bottom muds since 1920 . It should be kept clearly in mind, however, that the rich tubificid territory below Chillicothe has been referable to the pollutional, or sub-pollutional, and not the septic zone since that time. The leading member of the family in abundance there, also, has been a species of Limnodrilus (Limnodrilus hoffmcistcri), and not Tubifcr tubifc.r; though comparison of incomplete counts of samples from stations in the river above Chillicothe in 1923 with a few counts from Peoria Lake showed considerably larger ratios of Tubifcr tubifcr at the up-river, and so more heavily polluted, stations.

The recent changes in abundance in an upward direction in and above Upper Peoria Lake both of Limnodrilus hoffmcistcri and the dominant sphaeriid, Musculium transzcrsum, which seems able to thrive almost equally with that worm in polluted bottom, nlay well be, for anything that we know to the contrary, illustrations of an unusual adaptability more or less recently and locally acquired. In other words, we may perhaps suppose that both of these two species found the strength of the pollution over nuost of Peoria Lake rather too nuuch for them at the crest of the pollutional wave that seens to have reached its height shortly be- 
fore* 1920: but lave since found conditions just about to their liking. So far as their sources of food are concerned, it cannot be believed that there was any lack in that respect at any time in recent years; the Tubificidac utilizing the bacteria and fine organic detritus of the botton, and the Sphacriidac using a wide range of living or dead microorganisms, most of which are diatoms, unicellular algae, protozoa and the like, fron the always rich plankton population overhead.

The enormous increase in leeches in the section of river between Liverpool and Havana from $19: 4$ to 19.95 , which seens to have attained the proportions of a veritable epidemic for whatever organisms they were living upon, occurred in a section where one of their preferred food organisms (small bivalve Molluscu of the family Sphacriidac) was present in very great numbers; and as the leeches increased the Sphacriidac declined heavily. The more abundant species of leeches taken between Chillicothe and Havana from 1920 to 1!r:- as likewise before that tine, have been five or six in number (Hclobdclla stagnalis, Hclobdclla ncphcloidea. Dina microstoma. Erpobdclla punctata, and Glossiphonia complanuta), and are all known to feed upon snails, worms, various insect larvae, and other smaller botton animals ; the first two and the fourth also being scavengers. The most abundant one of all in recent collections from the midule Illinois River, Holobdclla stagnalis, has been noted particularly by Dr. I. P. Noore as being partial to Sphacriidac. A special table showing the rise in leeches alongside the decline in Sphacriduc (principally If Iusculium transicrsmm) in the 10 -nile stretch above Havana, 1924 to 19.25 . follows.

\section{T.HIT.F XII}

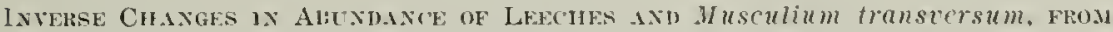

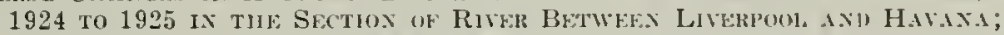
AVERAGL NTMUERS PlK S(qT'ARE YAR!

\begin{tabular}{|c|c|c|c|}
\hline Areas & Year & $\begin{array}{l}\text { Musculium } \\
\text { ransversum }\end{array}$ & $\begin{array}{c}\text { Total } \\
\text { leeches }\end{array}$ \\
\hline Channel .. & $\left\{\begin{array}{l}1924 \\
1925\end{array}\right.$ & $\begin{array}{l}17.952 \\
12.52 \mathrm{~S}\end{array}$ & $\begin{array}{r}1.660 \\
24,336\end{array}$ \\
\hline Extra-channel & $\left\{\begin{array}{l}1924 \\
1925\end{array}\right.$ & $\begin{array}{r}11,446 \\
4,38 S\end{array}$ & $\begin{array}{r}132 \\
5,593\end{array}$ \\
\hline Channel and extra-channel areas combined... & $\left\{\begin{array}{l}1924 \\
1925\end{array}\right.$ & $\begin{array}{r}12.7 \$ 5^{*} \\
6,465^{*}\end{array}$ & $\begin{array}{r}441 \\
10,275\end{array}$ \\
\hline
\end{tabular}

* Total spharridae, consisting almost wholly of Musculum transiersum.

Various instances (see tables on 1p). $t(0)-46$ s) of apparently inconsistent trends of leeches and Sphacriidac, $192+2+$ to 1925 , in other sections of the river are all readily harmonized with the case above considered or are easily explained as the result of other influences. The case of heavy decrease in Sphacridac in Ljper Peoria Lake, while leeches remained substantially unclianged can have been due to untustially heavy

* See $p .439$ and reference mentioned in fortnote on same page. 
feeding by carp in the early spring of 1925 ; or even possibly to unusually heavy mortality among the Sphacriidac as a result of overcrowding consequent upon their exceptionally rapid rate of increase between 1923 and 1924. The case, between the foot of Peoria Lake and Pekin, in which the leeches rose from only 5 to $3+1$ pounds per acre while the Sphacriidae increased slightly, calls merely for the comment that if the leeches had not increased so much very probably the Sphacriidac might have gone much higher. Comparisons as between the years 1920 and 1925 also show a few instances where both leeches and Sphacridae rose simultaneously over the five-year period, from more or less negligible to important numbers. Even if the correctness of the predator-victim relation be granted, however, it is reasonable to assume, up to a certain point, that the leeches might increase sharply as the species preyed upon increased; the point at which increase gave way to decrease in the small bivalves depending upon the time of attainment of an unbalance in the multiplication rates of the two groups.

Small or negligible increases, 1920 to 1925. in the Gastropoda and other cleaner-zeater groups. reaches of the river and Peoria Lake between Chillicothe and Beardstown. The group at that time included in all reaches not less than half a dozen species of unusually sensitive habit that were either generally abundant or abundant to common locally: Vivipara contectoides; Vizipara subpurpurca; Lioplax subcarinatus; Amnicola cmarginata; Amnicola limosa; and Somatogyrus subglobosus; all of which were practically wiped out in the deeper open water all the way from Chillicothe to Beardstown by the wave of pollution that reached its climax shortly before 1920 . Two other important members of this group, Campcloma subsolidum and Pleuroccra acutum were also destroyed in great numbers, but much less completely so than the six first-named species; Plcuroccra, particularly, holding out in fairly good numbers in all portions of the Peoria Lake channel where there was unusual current.

The recovery in the total Gastropoda in the three sections of Peoria Lake between 1920 and 1925 was so small as to be practically unmeasurable; the maximum rate of distribution (in the Middle Lake) being only 12 per square yard in 1925, consisting wholly of Campeloma subsolidum, which is unusually tolerant, and comparing with 49 to 130 per square yard of mixed species in 1915. Below Peoria, in the 10 miles between Havana and Liverpool, where the combined Gastropoda had averaged 496 per square yard in 1915 , they rose in 1925 to a bit less than 40 , from just half that number at the recorded low point five years before. The fact that more than half of the specimens taken in this section in 1925 were Vivipara contectoides, however (the rest being Campeloma subsolidum) seems to reflect to some extent the results of the previously mentioned improvement in the bottom dissolved oxygen supply below Copperas 
Creek Dan since 1923. Below Havana, to Beardstown, still greater variety was presented: two-thirds of the average consisting of three of the more sensitive species (T izifura contectoides; Amnicola cmarginata: and Amnicola limosa) and only one-third of then being the tolerant Campcloma subsolidum. Here average numbers per square yard had been is in 1915 ; had dropped to $2 \cdot ?$ in $19 \cdot 20$; and risen to 40 in 19.25.

Next after the Gastropoda the burrowing May flies of the genus Heragenia were by all odds the most important of the cleaner-water species of the muddy reaches of the middle Illinois River in the 1913-1915 period and earlier. At that time they were taken as tar north as Lpper Peoria Lake, and were present practically everywhere between that section and the lower end of the river, though their habit of depositing their eggs in swarms, often quite widely separated, sometimes resulted in their appearing rather scatteringly in a fixed progran of collections. In the sumner of 1920 the common species. Hcraycuia bilincata, did not appear at all in collections above the foot of Matanzas Lake, $t$ miles below Harana: since that rear it has been taken but a single time, and then in very small numbers, and very close to the edge. at one of the stations between Peoria and Havana. Below Havana, as we would expect, the species has been taken a little more frequently in the last few years: but did not occur at all in collections above Beardstown either in 1924 or 1925.

Anong the more important minor groups of the cleaner-water small botton fanna of 1913-1915 that have shown slight if any recovery at all since 1920 may be noted: the Hydropsychidae and Odonata, among insects: and among lower forms the Planaria. While all of these groups except the Odonata occasionally attained quite large numbers around ten years ago they did not either then or later anonnt to a great deal in averages, and need not occupy time here for discussion. Coloptera, represented alnost solely in recent years in the deep open water by a species of Stenclmis, have been principally confined to the vegetation near the margins both betore and since 1920 : the latter statement being also true of most of the Odonata. The principal Crustacea and Bryozoa of the open water are more or less tolerant and have received mention in that connection in another place.

Irregularity of abundance of the Chironomidac since 1020.

lar in abundance in all of onr recent collecting in the Hllinois River. As illnstrating sone of the more inportant changes, we found large decreases occurring between 1920 and 1925) in Upper Peoria Lake and in the ten miles above Havana, large increases in Middle and Lower Peoria Lake, and slight increases between Havana and Beardstown.

Most of the species taken in the sections of the river covered since 19.00 are pollutiona! or more than ordinarily tolerant: their natural tood supply, of settled and bottom plankton and organic detritus, is almost everywhere abundant: and there can be, therefore. hardly any question 
concerning the general suitability of conditions. Because of the frequency of new broods, of the same or different species during the warm season. it is not to be supposed that the tine of making collections would, in the long run, make much difference. This was verified in the case of the common Chironomus plumosus in Middle Peoria Lake in 1922 and 1923, the average number of individuals per unit area of lake bottom not varying seriously from one month to another between July and September.

The Chironomidac also have shown themselves more susceptible than any of the other larger groups of small bottom animals to the effects of floods in the Illinois River in recent years: dropping sharply between 1923 and 1924 in nearly all reaches between Chillicothe and Beardstown, as a consequence, with hardly any doubt, of the unusually long continued and severe stimmer floods of the latter year; and rising again sharply in the same areas between 1924 and 1925 , as the river came back to normal warm season levels.

Fuller details, with tables, of the changes in abundance of Chironomidac accompanying and following the 1924 high water are given on pp. $448-453$. and tables showing the abundance of midge larvae in all reaches in a series of years will be found on $\mathrm{Pl}$. $463-465$.

\section{Changes in Valuation as Fish Food and in Per Cent Composition by Weight}

Average poundage and composition of total stocks, by reaches, in 1915.
In 1915 , average valuations of the small bottom fauna between Chillicothe and the Lagrange Dam, about eleven miles below Beardstown, did not much exceed 350 pounds per acre in any area of open water except the short reach of less than ten miles immediately above Havana, during the Juneto-September season. Between Chillicothe and the Copperas Creek Dam the figures ran from around 1 iro to a little under $3 ; 0$ pounds per acre, and below Havana did not exceed 220 pounds. Quite in contrast with these records, the upper eight miles of the section between Copperas Creek Dam and Havana showed over 1,000 pounds per acre, and the lower nine miles, next above Havana, more than 2.700. At that time even the lower figures were not considered unexpectedly poor or unfavorable, in view of the generally rather hard or sandy botton in which they were taken excepting in Peoria Lake; and because in both the same and other sections of the river vastly richer areas were to be found in the connecting lakes and other backwaters. The comparatively low averages obtained in the three sections of Peoria Lake have since appeared, so far as they arose from shortage of a considerable number of cleanerwater species, to reflect measurable injury there by pollution before 1915 .

The composition of the average total haul in 1915 in all the openwater reaches, including Peoria Lake, was made up always largely, and 
frequently almost wholly, of some half-dozen species of large and small Gustropoda, all but one of which have since almost completely disappeared from the areas above the Copperas Creek Dam. The average per cent by weight of the total haul made up by these Gastropoda in various reaches is shown in the table that follows, which includes percentage showings as high as 95 and only one lower than 60 . In the I'eoria Lake area rather less than a third of the totals of Gastropoda belonged to the unusually tolerant viviparid species, Campcloma subsolidmm: and in the Liverpool-Havana section a not very different fraction; pollution at that time not yet having affected seriously any of the more sensitive nembers of this group of snails.

In 1915, Sphacriidac occurred in numbers large enough to affect valuations importantly in only three of the eight sections here recognized: viz., in Upper Peoria Lake, where they made up $\$ 3$ per cent of the total on the average; in the first section below Peoria Lake (Peoria and Pekin Union Railway bridge to Pekin) where they contributed 31 per cont: and in the rich Liverpool-to-Havana section, where the percentage was also 31 .

\section{TABLE: XIII}

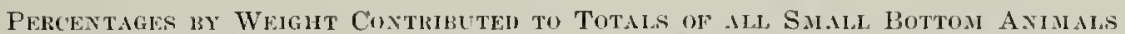

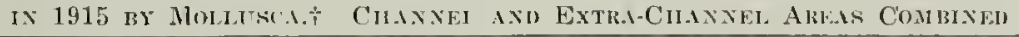

\begin{tabular}{|c|c|c|c|}
\hline Reaclies & $\begin{array}{l}\text { Av. Ibs. } \\
\text { per acre }\end{array}$ & $\begin{array}{c}\text { Gastropoda } \\
\text { per cent }\end{array}$ & $\begin{array}{c}\text { Sphaeriidae } \\
\text { per cent }\end{array}$ \\
\hline Upper Peoria Lake................... & 170 & 51 & 43 \\
\hline Middle Peoria Lake*.................. & $\cdots \cdots$ & $\ddot{i}$ & $\cdots$ \\
\hline Lower Peoria Lake................... & 330 & 95 & \\
\hline P. P. U. Bridge to Pekin... & 230 & 62 & 31 \\
\hline Pekin to Copperas Creek Dam.......... & 367 & So & \\
\hline Copperas Creek Dam to Liverpool........ & 1,064 & So & \\
\hline 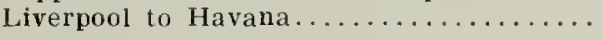 & 2,757 & 68 & 31 \\
\hline Havana to Lagrange Dam..... & 263 & 86 & \\
\hline
\end{tabular}

* Unimportant percentages of sphaevidue disregarded.

* Uncluded in tpper. Penta Like, 1915, when collections in the Middle Lake were confined to its npper third.

The change in composition of the fauna and the decline in poundage in most raches betrecen 1015 and 1920 .
The principal collecting of the stmmer of $19 \% 0$ was done in the region between Chillicothe and the foot of Lower Peoria Lake. Below I'coria, the two sand-and-shell reaches between Wesley and Pekin and next below Copperas Creek Dam, as also the short, more or less munddy section between Pekin and the dam. were passed over, and the bottom collecting was confined to the previonsly very rich short section next above llavana and the stretch of about 201 miles of sand-and-shell or clay bottom immerliately helow Havana and above the foot of Hickory Island (about 111 miles above Beardstown). 
Both in the three subdivisions of Peoria Lake and in the first 20 miles below Havana, all of which areas had been only moderate producers before 1920, the reversal in composition of the fauna and the substitution of pollutional or unusually tolerant Tubificiluc, Chironomiduc, and Sphacriidac since 1915 for the Gastropoda and other cleaner-water species formerly dominant there, offered more striking and significant evidence of the increased pollution than the declines in poundage in the five years. Even the average poundage in the Lower Lake was cut down to about a third of the 1915 average, though the replacement of the cleaner-water by the pollutional and unusually tolerant forms served actually to increase the average poundage in Upper Peoria Lake and the upper portion of the Middle Lake in the five year interval of increasing pollution that ended in 1920. The outstanding decline in average poundage, accompanied by radical change in the composition of the small bottom fatma, occurred in the nine miles between Liverpool and Havana, where the high average of $2,75 \%$ pounds per acre in 1915 gave way to an average of only 195 pounds five years later.

The shifts in the composition of the fauna between 1915 and 1920 in the three sections of Peoria Lake reduced the Gastropoda almost 100 per cent, or practically to zero. The only surviving nembers of the group showing a trace in open water in 1920 belonged to the single unustally tolerant stagnant-water form, Campcloma subsolidum, or, where there was unusual current, to the only slightly less tolerant current-loving Plcuroccra acutum. Here, as the Gastropoda fell, the combined pollutional and unusually tolerant Chironomidae and Tubificidac rose to figures, in terms of weight per acre, equal to 85 to 95 per cent of the average total haul.

In the sections of the river between Liverpool and Havana and between Havana and Beardstown the average poundage of Gastropoda was cut in the five years 80 to 98 per cent and the Chironomidac (principally the pollutional Chironomus plumosus) in the first-named section

\section{TABLE XIV}

Princhpal Changes ix Valuation axd Per Cext Composition by Weigit of All Suall Bottom Aximals, 1915 to 1920. Chaxjel axi) ExtraCitañel Areas Combixied

\begin{tabular}{|c|c|c|c|c|c|c|}
\hline Reaches & \multicolumn{2}{|c|}{$\begin{array}{c}\text { Average lbs. } \\
\text { per acre }\end{array}$} & $\begin{array}{l}\text { Gastrop- } \\
\text { oda } \\
\text { per cent }\end{array}$ & $\begin{array}{l}\text { Chiro- } \\
\text { nomidae } \\
\text { per cent }\end{array}$ & $\begin{array}{c}\text { Tubi- } \\
\text { ficidae } \\
\text { per cent }\end{array}$ & $\begin{array}{l}\text { Gastrop- } \\
\text { oda } \\
\text { per cent }\end{array}$ \\
\hline Year & 1915 & 1920 & 1915 & $19 ? 0$ & 1920 & 1920 \\
\hline Upper Peoria Lake.... & 170 & 256 & 51 & 52 & 33 & 3.5 \\
\hline Middle Peoria Lake.... & $*$ & 42 & $\%$ & 78 & 18 & \\
\hline Lower Peoria Lake..... & 330 & 72 & 95 & 89 & 4 & \\
\hline Liverpool to Havana.... & 2,757 & 195 & 68 & 53 & & 19 \\
\hline Havana to Beardstown.. & 263 & 119 & 86 & 30 & & 42 \\
\hline
\end{tabular}

* Included in Lipper Peoria Lake, 1915, when collections in the Midde Lake were confined to its upper third. 
made up 53 per cent of the arerage haul. The only surviving Gastropoda in the first nine miles above Havana belonged to one or the other of the two unusually tolerant species above mentioned; and the more sensitive large Firiparidac and the smaller Ammicolidac, which had been a prominent feature of this streteh of river in 1913-1915. were not taken at all. Below Havana the changes were less severe. though even here the Gastropoda diopjed from 86 per cent of the average total haul to considerably less than half of it: while all Gastropoda that were found in 1920 belonged to the tolerant species of Plcurocora above mentioned. Here also the Chironomidac. which had made up a negligible portion of the total poundage in 1913-1915, had multiplied until they contributed more than 30 per cent of it: and the bulk of them belonged to the pollutional species, Chronomus plumosus.

Great increases in poundage in all reaches since 1920, duc to multiplication of the pollutional or unusually tolerant groups.

While in 1920 valuation figures higher on the average than in $191 \mathrm{j}$ were obtained only in Upper Peoria Lake, where the gains in the pollutional and umusually tolerant Tubificidac, Chironomidac, and Sphacriidac had alrearly ontstripped the losses in Gastropoda and other cleaner-water species, it was clear by $1922-1923$ that the continued rise of the single munsually tolerant sphaeriid, Musculium transa'crsum, was rapiclly lifting average poundages to formerly unknown levels also in Middle Peoria Lake and in the !-mile stretch of formerly very rich botton just above Havana. The full extent of the change was not realized till the stmmer of $19 ? \mathrm{l}$. It that time the returns from Upper Peoria Lake showed an average poundage more than twenty-five tines that of 19020 and more than thirty-nine times that of 1915 ; the Middle Lake more than twenty-six times the average of 1920 : and the Liverpool to Havana section alnost twice the average poundage of 1915. and more than twenty-five times that of 1920 . These great production averages, in 19:4. of 6.33 i pounds per acre in the Upper Lake. 1.110 pounds in the Middle Lake, and, \pm 996 pounds in the short section just ahove Havana, were almost wholly due to the rapid multiplication of unusually tolerant Sphacriidac (principally Musculium transecrsum), of which the contributions to the average total haul ran 80.4 per cent, $1: 2$ per cent, and 94.3 jer cent, respectively.

Although there was a slarp decline in Sphacridac in Lpper Peoria Lake between $192+$ and 1995 (still leaving the total poundage about six times the 1920 figures and more than nine times the 1915 figures), the rise in total poundage continued strongly upward after 1921 in the Middle Lake, going in that area from 1,100 pounds per acre to $?, 014$ pounds, due largely to increase in Splacriidac. It rose moderately also in the Liverpool-Havana section between 19.4 and 1925 , from 4.996 pounds to 5.355 pounds, in spite of a decline of large proportions in M $/$ sculium. transzcrsum. accompanied by a great increase in leeches known to be predatory witli reference to many of the other small bottom species. 
and of small bivalve Mollusea in particular. The decrease in Sphaeriidac in the Upper Lake between 1924 and 1925 was not accompanied by a corresponding rise in the leeches; and it may have been a consequence of temporarily increased feeding by fishes in that area, following a summer of almost continuous flood, which could easily bring large fish up the river in good numbers, but keep them occupied in the shallower, temporarily overflowed, or "brush", areas during its continuance.

Perhaps the most remarkable change of all between 1924 and 1925 was the extension of the rapid gains in average total poundage to Lower Peoria Lake and to the previously comparatively poor sand-and-shell or lightly silted reaches between Wesley and Liverpool, and below Havana. In the summer following $192 t$ the average poundage of the Lower Lake had risen from 230 to 1,009 pounds per acre, due to large increases in three of the pollutional or unusually tolerant groups,-Tubificidae, Chironomidae and Sphacriidae. In the two short sections between the foot of the Lower Lake and Copperas Creek Dam the rise in average weight was from less than 250 pounds per acre to the neighborhood of 1.300 ; in the first case this was due principally to an enormous increase in Tubificidae; in the second, to still greater increase in the midge larvae. Between Havana and Beardstown in the same twelve months the average total haul was multiplied more than eight times, standing in 1925 at 1,135 pounds per acre, or almost ten times the average 1920 figure and almost five times the average of 1915 .

The increase between 1924 and 1925 below Havana was alnost wholly in the unusually tolerant single kind of Sphaeriidac (Musculium transzersum) that has recently been contributing so heavily to poundage figures in Peoria Lake, and that neither in the 1913-1915 period nor since 1920 until 1925 had contributed at all importantly to totals between $\mathrm{Ha}$ vana and Beardstown. The very sudden appearance in 1925 of this small bivalve in such large numbers at stations in the first 31 miles below $\mathrm{Ha}$ vana, where in 1913-1915 the greater part of the bottom was sand and shell, or otherwise harder than botton usually selected by that species,

TABLE XV

Average Valuation, in Pounds per Acre, All Small Bottom Animals; Channel and Extra-Cilannet, areas Combined*

\begin{tabular}{|c|c|c|c|c|}
\hline Reaches & 1915 & 1920 & 1924 & 1925 \\
\hline Upper Peoria Lake.. & 169.7 & 255.8 & $6,737.8$ & $1,565.7$ \\
\hline Middle Peoria Lake.. & & 41.8 & $1,110.6$ & $2,014.0$ \\
\hline Lower Peoria Lake... & 329.9 & 72.1 & 230.4 & $1,009.2$ \\
\hline Foot of Peoria Lake to Pekin & 230.0 & $\ldots$. & 229.9 & $1,356.3$ \\
\hline Pekin to Copperas Creek Dam. & 367.5 & $\ldots \ldots$ & 143.0 & $1,275.3$ \\
\hline Copperas Creek Dam to Liverpool. & $1,063.7$ & $\ldots$ & 51.5 & $\ldots \cdots$ \\
\hline Liverpool to Havana.............. & $2,756.7$ & 195.0 & $4,995.9$ & $5,351.1$ \\
\hline Havana to Beardstown..... & 263.2 & 119.0 & 142.3 & $1,135.8$ \\
\hline
\end{tabular}

* The composition of these totals is shown in the tables on pp. 460-468. 
can be explained only as in large part probably a special consequence of the unusual and long-continued summer flood of $19 \% 4$. It seems almost necessary to assume, in fact. that the flood not only carried down and deposited unusual amounts of ricl sediment in certain parts of the $\mathrm{Ha}$ vana-Beardstown section, but that it also actually moved good numbers of very young individuals of . I usculium in the midsummer season of their greatest abundance, along with the sediment. many miles downstream. It is not, in tact, at all likely that a similar effect. both in enrichnent of the bottom deposits and in the multiplication of this particular species. could have been accomplished within the space of twelve months it the 1924 flood had been confined to the usual short spring period. That has ordinarily been in recent vears somewhere between the end of January and the end of April. When collections of .Musculium transicrsum usually show practically all adults. which are much better able to hold their anchorage in soft bottom than the very young.

In the section of this paper inmediately following. the recent strong upward surge in abundance and valuation of the Splacrildac is shown with a fair degree of probability to be a normal phase of a pollutional cycle or succession that evidently takes at times several rears to complete itself. Varions uneliminable factors may also be concerned. In particular, it should be pointed out that a portion of the recent very great poundage increases in the polluted sections of river above Beardstown nua reflect permanent reduction since $1913-1 ! 1 . ;$ in the population of bottonranging fishes, with consequently decreasch inroads. for securing food. on the small bottom animal population. At least we can hardly assume that the increases have been wholly due in all areas to an abnormal multiplication rate under the stimulus of a richer food supply, of its kind. that goes with a more polluted river. The comparison of commercial fisheries census data of 1908 to $191 \pm$ with those of 1921 and $192 ?$ to some extent bears out these strictures.

\section{Temporal Succession of the Leading Groups of Pollutional or Unusually Tolerant Forms in the Polluted Reaches Below Chillicothe}

Between 1990 and 1495 an accumulation of rery suggestive evidence has cone into our hands bearing on the order in which the more important pollutional and unusually tolerant groups of the small bottonn animals came into prominence as or after the more sensitive Gastropoda and other groups had disappeared from most of the reaches abore Beardstown shortly aiter 191\%. For various reasons, however. comparisons based on the per cent composition of the average haul expressed in numbers per unit of bottom area have not been found as satisfactory tor the purpose intended as those based on weight. On the basis of abundance, to take only a single example, the Tubificidae were shown to be the leading group 
in Upper Peoria Lake in 1920, with an average of 2, 163 individuals per square yard, although the Chironomidac, with decidedly smaller numbers (only 733 per square yard, to be exact), contributed much more heavily to average poundage over the same area at the same time. Next, it is found that by that method of comparison the Tubificidac continued to hold their dominance in that section of river continuously (except for 1921 , when we made no collections) from 1920 to 1925 , though in both 1924 and 1925 and possibly also in 1922 and 1923 the Sphacriidac had risen to the leading place, on a bulk and weight basis, having in fact a margin of around 300 per cent over the Tubificidac in 1924.

By scheduling the various groups on a basis of per cent composition by weight, on the other hand, we obtain a picture of the true "complexion" of the small botton fauna rather than its population-distribution expressed in confusingly different sized units, and see the main features of a succession that seems to have a real biological basis. Using this method of comparison, we find that the Chironomidac, represented very largely by the single pollutional species Chironomus plumosus, led in all reaches between Chillicothe and Beardstown in 1920 where Gastropoda had fallen to less than 20 per cent of the average valuation total, this including the three sections of Peoria Lake, and the nine-mile section immediately above Havana; and that Tubificidac were following instead of leading in the two sections of Peoria Lake in which they were most abundant that year.

In 1924, an essentially changed picture is presented; with the Sphacriidac, in all subdivisions of Peoria Lake and part of the river reaches above Havana, holding the place that was held by the midge larvae in 1920; and with the Tubificidac holding first place in two of the river reaches between Peoria and Havana and in the 31-nile section between Havana and Beardstown. In 1925, the Sphacriidac still held their lead in the three subdivisions of Peoria Lake and in the section next above Havana; and the Tubificidae were still first in weight between the foot of the Lower Lake and Pekin, though they had lost their lead to the Chironomidac between Pekin and the Copperas Creek Dam and to the Sphacriidac between Havana and Beardstown.

It is evident that we have in the above data strong hints of some kind of a cycle. In order for this cycle to emerge into full light, however, it is necessary to have in mind a few additional features of the biology not yet mentioned. The first of these is that, in very badly polluted muds in streams already infected with those worms farther up, Tubificidac are ordinarily the first of the pollutional or unusually tolerant groups to attain not only dominant numbers but dominant bulk and weight as well. This was well illustrated in work in the upper Illinois in 1911-1912, and more recently in studies on some less important water-courses in the State. The reason for it is not at all obscure, being the simple fact, apparently, that the worms can float or roll into the new area; whereas the Chironomidac must ordinarily make their entrance from the outside, on the wing; and the Sphacriidac, excepting 
those times (as in 19:24) when unnsual summer floods seen to have moved their young and half grown, depend principally on the slow process of creeping over the bottom.

If the above is a substantially correct view, the three sections of Peoria Lake and the ten-mile stretch of nud bottom next above Havana are seen to have been very probably in the second (chirononid) stage instead of the first (tubificid) stage of the pollutional-biological cycle in the summer of 1920 . This would ordinarily also mean that a short time before 1920 Tubificidae were probably the dominant group in bulk and weight in all or most of those areas. Though it is not necessary, in order for this to have been the cane, (at least in Upper Peoria Lake) to assun1e that the pollution was greater in these parts of the river shortly before than during 1920 , it is noted that the tendency of the data on the volume of business done hy the Chicago Packers trom 1916 to 1920 and of other evidence* is to suggest that it was at least for a time measurably more so.

The third (sphaeriid) phase of the cycle had attained full swing in the three subdivisions of Peoria Lake and in some reaches farther down river by or before 1924 , incomplete valuation figmes for 1922 and 1923 stuggesting that the Sphacridac had attained the lead in point of weight in Lpper Peoria Lake as early as 19:2 or 1923. It is necessary to point out also that dominance of the Sphacridac (as represented almost wholly by the single species. Musculium transiorsum) in areas where Tubificidac and Chironomus plumosus had previously held the lead, does not necessarily imply improvenuent in sanitary condition. That species. in fact, accompanied the Tubificidac as far up river as LaSalle in both $192+$ and 192.5 ; often attaining large numbers side by side with tens to hundreds of thonsands of Tubificidac per square yard. The evidence from the botton dissolved-oxygen readings, already presented. indicates also that there was no important change in the underlying sanitary condition above Copperas Creek Dan between 1920 and 1925.

Evidence of a minor succession of Twbificidac-ChironomidaeSphacridac in several reaches below Peoria Lake in the two years 1924 . 1925 is also little less clearly inplicit in the data. The sudden elevation of the Tubificidac to first place in weight between the foot of Peoria Lake and Pekin, between Pekin and Copperas Creek Dam, and between Havana and Beardstown in $192+$ was without much doubt in great part the result of an involuntary migration downstrean of the worms during the heavy and continuous summer floods of that year. It stands also as corroborative evidence of considerable ralue that putrescible sediment is carried during floods far past its nomal resting place under nore stable hydrographical conditions: and goes far toward explaining the lag not inf requently noted between the condition of the bottom sediments and the dissolved oxygen and plankton in the moving water overhead. It was very probably largely due to the temporary

* Richardson, R. E., Bull. Ill. Nat. Hist. Survey, Vol. XY, Art. V. pp. 325-332, Aug. 1925. 
nature of this minor wave of pollution in the section of river between Havana and Beardstown that the Sphacriidac displaced the Tubificidac as dominants there by the next summer. In the short section of river between the foot of Peoria Lake and Pekin, on the other hand, the Tubificidae still held the lead in 1925; and between Pekin and Copperas Creek Dam the cycle had progressed only to the second stage (that of Chironomidae) by the summer of that year.

The succession above described is essentially temporal in character, representing the order of attainment of dominance of three groups of substantially equal tolerance, within the limits of the zone (mesosaprobic. or pollutional to sub-pollutional) between that of septic and cleanerwater organisnis; and in territory where no changes sufficiently great as to have altered zonal boundaries are known to have taken place between the dates of its inception and completion. It has no essential connection with the broad zonal succession from septic to clean-water forms that occurs over a period of years in a circumscribed area as pollution gradually decreases; or from the upper to the lower reaches of a stream septic at its upper end but long enough to permit fairly complete biological self-purification in the run to its mouth.

While leeches came near exceeding either Tubificidae, Chironomidae. or Sphacriidac in weight per unit of botton area between Liverpool and Havana in 1925 , their numbers and weight were as a rule irregular and unimportant in all other sections of river covered by the collections since 1920 . They seem, so far as represented by the five or six conmoner species participating in the unusually large leech totals of 1925 , to have no necessary connection with pollution, although apparently able to stand about as much of it on occasion as the other three groups named. Their sudden appearance within a limited area in very large numbers that year does not fit into the succession above described at any point. but may have had some connection with the floods of the summer of 1924 and the further fact that at least three of the commoner ones, including the most abundart of all. Helobdella stagnalis, are scavengers. Leeches have been observed recently in Rock River swimming near the edges in strong current after rapid rises of water level, and similar observations have been made on the Illinois River. The long-continued summer floods of 1924 may have given rise to considerable dispersal of leeches and at the same time seem to have favored an unusual rate of multiplication of the small bivalve Mollusca (Sphacriidac) on which several of the leeches feed. Floods also wash in various dead animals, terrestrial and otherwise. which might add to the food supply of the scavengering kinds; and unusual mortality anong the Sphacriidac, following the unusual multiplication rate and resultant crowding mentioned, may to some extent have served the same purpose.

In the following table illustrating succession, based upon average weight figures in pounds per acre, the small numbers at upper right of group names represent the percentages of average total hauls contributed by the groups; groups with percentages under 5 being ignored. The 
larger figures at left preceded by letter $A$ are the phase numbers of the groups constituting the long pollutional cycle that started shorty before 19:0: phase ntmber 1 (Tubificidat dominant) having been missed. and apparently falling somewhere between 191: and $19: 20$. The large figures at left preceded by letter $B$ are the phase numbers of the ninor and apparently temporary pollutional cycle that started in certain reaches below Peoria Lake during the severe summer foods of 1924 .

\section{TABLE XTI}

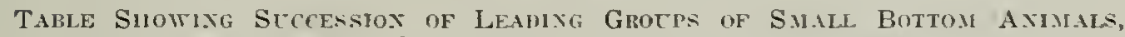
Based ox Percextage Compositrox by Weigut of tile Arerage Hati; 1915 то 1925

Exponents are perentages of the average tolal poundages per aere contributed by the leading groups of small bottom animals

1915

Upper Peoria Lake...............

Middle Peoria Lake

Lower Peoria Lake................

P. P. U. R. R. Bridge to Pekin.......

Pekin to Copperas Creek Dam.......

Copperas Creek Dam to one mile above Liverpool ...............

One mile above Liverpool to Havana.

Havana to Lagrange Dam..........

Gastropoda

Gastropoda $a^{23}$

Gastropoda

Gistroporan

Gastropoda

Gastropodar

fiastroporla sphaeridaes

sphaeridaen sphaeriidae

Sphaeridae sphaeridae:1

sphaeriadae

\section{0}

Upper Peoria Lake..... A2
Middle Peoria Lake.....
Lower Peoria Lake.....

P. P. U. R. R. Bridge to Pekin.................

Pekin to Copperas Creek Dam................

Copperas Creek Dam to one mile above Liverpool ................

One mile above Liverpool to Havana ..........

Havana to Beardstown...

\begin{abstract}
no collections
\end{abstract}
no collections

no collections

* Holdover from 1913-1915.

† Collections from upper third of Middle Peoria Lake included with Lpper Lake in this part of the table. 
TAILE XVI-Concluded.

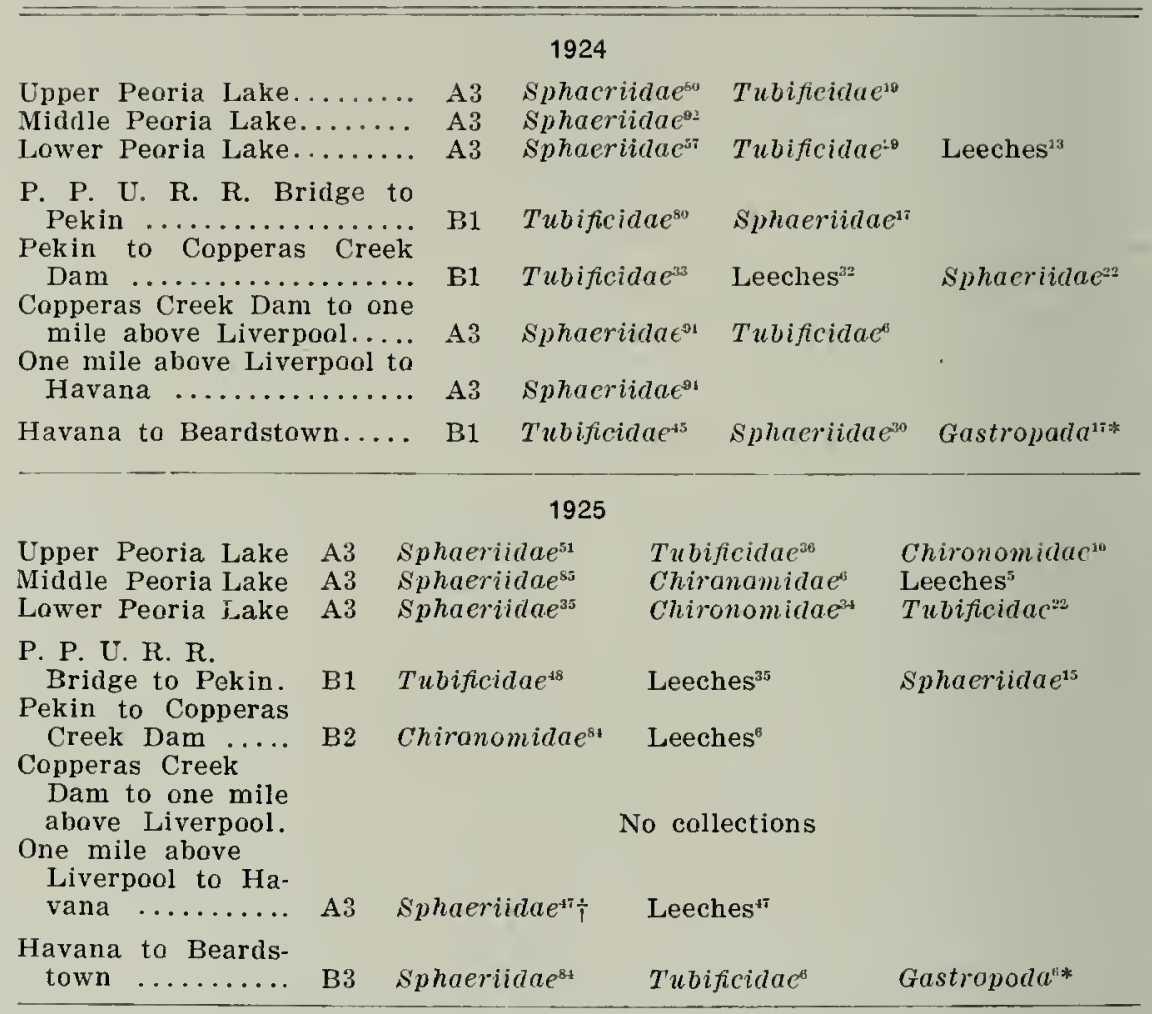

+ The leeches are apparently preying upon the Sphaeriidae, which are just abdicating first place, which they held orer from 1924 .

* Largely holdover from 1913-1915.

\section{Competitive Relations Among the Small Bottom Animals}

Among the three groups of small bottom invertebrates that have figured largest in abundance and valuation in the muddy reaches of the Illinois River above Havana since 1920 (Tubificidac, Sphacriidac, and Chironomidae), it cannot be said that competition for food has been at any time an important influence on numbers. Insofar as these three groups use the same food, namely, the living bottom plankton and bacteria and the settled plankton and fine organic detritus, they are conpetitors in a general sense. But by reason of the practically limitless amounts of those materials available, at least in the reaches of the Illinois River with less current, competition for food is probably non-existent in actual practice, although all three groups have often in recent years been found associated in large numbers over the same bottom area. 
The gastropod Mollusca, embracing sereral species of large snails capable of ingesting objects as large or larger than the eggs of many insects, and having the habit of taking in practically everything that lies in the path of their tongues as they crawl over the incrusted surface of sticks, or stones, or dead or living shells, have bulked so small in the Illinois River bottom fama above Beardstown in recent years that depredation by them on egg or very immature stages of other organisms may be regarded as little if any more than negligible. In years previous to 1920 , on the other hand, the fact that they once becane dominant in an area seems to have given them a more or less permanent and. if abundant, often almost misputed foothold there. This was with little doubt in some part due to the inability of other bottom invertebrates, which plaster minute eggs on solid objects on the bottom. to multiply in great numbers where the rasping tongues of hundreds or thumsamds of Campcloma and Viripara per spuare yard were in daily operation. The hold of the larger Gustropoda on the territory once uccupied by them in great numbers was doubtless also strengthened against some otherwise likely associates, by the smothering blanket of slime spread over and binding together the fine bottom ooze and shutting of the air over large areas from eggs or very young stages of other species living therein; and against still others (as possibly Tubificidae and young Chronomidac) by the sheer hulk, weight, and slow notion of these snails. Which conld easily result in smothering many small organisms of other species nufortumate enough to be in their way.

Thus it is no surprise to find that our older data obtained when large Gastropoda led in abundance in many reaches of the Illinois River. strongly suggest that great numbers of these snails act as a bat against the increase in large numbers in their inmedite neighlorhood of either Chironomidac, Sphacriidac, or Tubificidac. Only those Tubificidae of less pollutional habit are here referred to. Tubifer tubifc.s being malikely, because of its more distinct preference for very foul hottonl, to reach great numbers in nucis inhabitilsle by the more sensitive liniparidar even if the large snails were not there.

Of the larger species of Sphacriidac it was noted in rears prior to 1920 that Muscutium transicrsum was frequently comparatively abundant along with considerable numbers of large Triparidac, though not likely to be present at all where l'iriparidar reached maximum mumbers. The indicated greater immunity to both direct and indirect injury by the large snails exhibited by this snall bivalve, than by Chironomidac and Tubificidac, quite possibly had some connection witli the fact that they are born alive with a fully formed shell, and of a size rather larger than that of food objects usually taken by the large Gastropoda.

Leeches, concerning whose depredations on Sphacriidac mention has been made in a preceding section, are also known to prey upon Tubificidac, but we find no positive evidence of that in our recent bottom famna data. In the stretch of river between Liverpool and Havana the Tubificidac in fact increased abont ?0 per cent between $19.2+$ and $19 \% 5$, 
as the small bivalves, thought to be the object of leech depredation, declined. Other strictly predaceous bottom species that are known to affect the abundance of the less well protected small bottom organisms in many waters, such as certain larval Colcoptcra and Odonata, liave not been represented in important numbers in recent Illinois River and Peoria Lake collections from the deeper open-water areas.

\section{Accessibility, Quality, and Extent of Use as Fish Food}

Probably quite as effective as competition among themselves in keeping down numbers of some groups of the small bottom animals is their use as food by the more common bottom-feeding fishes. Also there is not lacking circumstantial evidence that neglect of some groups by the fishes permits them at times to increase while the stocks of others are being drawn down.

The evidence from Professor Forbes studies on the food of the buffalo, red-horse, and carp-suckers from scattered localities in Illinois; those of Cole on German carp in Lake Erie; and those of the State Natural History Survey in the past three years on the feeding habits of carp, buffalo, and other sucker-mouthed fishes of Rock River, strongly suggests that, in general, these fishes prefer small bivalve mollusca (Sphacriidac), various kinds of larval midges (Chironomidac), the burrowing May-flies (Ephemerinac), and the larval caddis-flies (Hydropsychidac) to Tubificidac, leeches, and large Gastropoda. The evidence as respects avoidance of the Tubificidac by the large bottom-ranging fishes is of course not conclusive at present, consisting in their almost total absence from more than a thousand stomachs examined (from Illinois waters only), although the worms are known in a good portion of the cases to be present in at least moderate numbers in the areas from which the fishes came.

Several possible reasons for this seeming neglect of the Tubificidae by the principal large bottom-feeding fishes suggest themselves. For one thing, the Tubificidac are generally quite small, and are accustomed to withdraw themselves instantaneously into their tube-like burrows, excavated in the bottom nuud, at the least disturbance. This habit may easily afford effective protection to them when their numbers are moderate and when they are interspersed between larger, more accessible, and more acceptable small bottom kinds, as is apparently most frequently the case where much feeding by the large bottom-ranging commercial fishes goes on. When they are extremely abundant, on the other hand, the dissolved-oxygen supply is likely to be so low that little feeding by the fishes can be believed to take place during the active warm season in their territory. For the discussion of data that suggest, on the other hand, that the large botton-ranging fishes do occasionally under unusual conditions, and perhaps more or less accidentally, eat large quantities of Tubificidac, see page 450 . 
The complete exclusion of the Tubificidac from the dietary of the bottom-feeding fishes, even if it were to occur where they are most abundant, would cut down the total stocks of small bottom animals available, measured in pounds per acre, much less than the exclusion, muder recent conditions, of the Sphacriidac; but, on the average, apparently, not much if any less than the exclusion of the Chironomidac. Thus, in Lpper Peoria Lake in $192 \%$, the Tubificidac amounted on the average to approximately 1,300 pounds out of a total of all kinds of small bottom animals of somewhat more than 6.000 pounds per acre; while the Sphacriidac averaged well over 5.000 pounds. Their occurrence in average poundages over 500 to the acre durmg the years $192 t$ and 1925 , was confined to three sections of the Illinois River, all above Pekin. In most of the few cases since 1920, in fact. where the percentage of the total weight of all small bottom animals made up of Tuhificidac was high, the total weight of all kinds was low, and the average weight of the worms was considerably under 200 pounds per acre.

In rather marked contrast to the Tubificidat, the four more important of the apparently preferred groups in Illinois streams, the Sphacriidac, the Chironomidac, the Ephemeridac and the Hydropsychidac, are all visibly larger: and they are accustomed, even when burrowers (as are some of the Chironomidas and all of the formerly common Ephemeridac of the Illinois River), to remain for considerable times outside of their burrows. Even the larvae of the more abundant caddis flies of the Illinois and Rock Rivers (the $H_{y}$ dropsychidac) live a free life upon the botton much of the time, though they show a preference for crachs or crevices in rock or other hard bottom when it is available, and withdraw into a hard case made of sand grains just hefore pupation. In spite of the rather large degree of protection afforded them by such habits they are not a small element in the food of several of the larger botton-feeding fishes of these rivers.

Because in the season of $19: 5$ the total weight of the leeches in the reach Liverpool to Havana rose to the unprecedented figure of over ?:,500 pounds per acre, it is of interest, next, to inquire whether this rather large supply of potential animal food was likely to be of any important actual value to the large commercial fishes that range the botton of the open Illinois River where the leeches were found. Such answer as is afforded by the study of data from a variety of sources is not in faror of placing a high value on the leech crop as fish food. It is true that Professor Forbes* more than forty years ago found leeches in the stomachs of 3 out of 113 channel cat examined from Illinois waters, and also in the stomachs of 6 ont of 49 bullheads; and large leeches are reported as being used occasionally as bait for channel cat in Rock River. But channel cat and bullheads made up then as now only a rather small percentage of the total fish catch, whereas the more important group. from the point of view of bulk and weight and numbers, including the bottom-feeding 
buffalo, red-horse, and suckers, furnished only a single specimen which had eaten a leech out of a total of $10 \%$ specimens examined. Colè, in studying the food of carp in Lake Erie (1903) found no leeches at all in 33 specimens examined, but did find an abundance of small bivalve Mollusca and Chironomidac, much vegetation, and other minor nnaterials. In our examination of the food of the larger botton1-feeding fishes of Rock River, not completed, 92 specimens of carp have shown no leeches taken as food; 109 buffalo, of three species, showed only one leech eaten (by a mongrel buffalo): 116 suckers and red-horse and silver carp of various species showed no leeches eaten at all; and over 900 channel cat and 40 other catfishes of various species showed no leeches eaten at all. Leeches evidently play a more important part in the food of shore fishes, particularly those that feed anlong vegetation-including sunfishes, perch, black bass, some perch-like fishes, sculpins, and bullheads, as is shown by Pearse $\neq$ in his studies (1915-1916) on the food of fishes in some of the inland IVisconsin Lakes.

The younger and thinner-shelled specimens of the large gastropod Mollusca are known to be used as food by the large species of red-horse, but did not appear in the food of buffalo, suckers, or silver carp exanined by Professor Forbes from Illinois WVaters. Neither have they been found by us in any of the specimens (upwards of 300) of carp, buffalo, redhorse, etc., examined in the last three years from Rock River. These snails, it is true, are comparatively rare in most of the Rock River. But in those reaches of the Rock River about and above Rockford, where large Viriparidac are common, white they do not appear in the buffalo, suckers, red-horse or carp stomachs, they are found frequently in the stomachs of channel cat, the only fish we at present know of which seems capable of handling them. Professor Forbes called attention to this nearly 40 years ago, and today we find, as he did then, that the large channel cat are able to withdraw the bodies of full-grown heavy-shelled specimens of Campcloma and Plcuroccra from the shells and swallow them with no hard parts attached except sometimes the operculum. The value of these larger snails as fish food thus appears to be quite limited, much as that of the several kinds of common leeches; both entering into the food, for the most part, of a single minor group of the large bottom-ranging fishes (the catfishes), and being avoided by the more important, carp, buffalo, and allied kinds. From the point of view purely of accessibility, then, of the more important constituents of the small bottom fauna as fish food, the destruction of the large Gastropoda in the Illinois River by pollution since 1915, and their replacement by still larger numbers and greater total bulk of the more acceptable and more accessible small bivalve Mollusca (Sphacriidac), niay be regarded as a benefit rather than an injury to the commercial fishery, at least in those areas where the pollution which ac-

t Cole, L. T., The German Carp in the United States. Rept. U. S. Bureau of Fisheries, year ending June 30, 1904, Appendix, pp. 523-641.

\$ Pearse. A. S., The Food of the Shore Fishes of Certain IVisconsin Lalzes. Bull. U. S. Bureau of Fisheries, Vol. XXXV, 1915-1916, pp. 247-291. 
complished the change does not hold the oxygen down to or below the danger point for the fishes during the active feeding season.

On the score of quality-including both healthfulness and suitability for producing edible quality in fishes which consume it - the recent "rich" foud supply in the more polluted sections of the Illinois River botli above and for some distance below Peoria seems open to indictment on more than one count. While "gassy" fish have been complained of at various places along the Illinois River for many years, these complaints bave become much more insistent in the Peoria Lake region since 19?0). Since that time eastern receivers have been accustomed to malie price discrininations against Illinois River fish, nore particularly, carp, for that reason. The local complaints have agreed that the "gassy" taste is nore pronouncer in winter, when the river and lakes are frozen over, without, however, advancing a satisfactury explanation why that should be so; the putrefactive processes in the botton sludges being clearly nutch less active and productive of nuisance under winter temperatures than during the warm season. On reflection it is seen that a very simple and purely physical theory satisfactorily accounts both for the central fact of "gassiness" and for its stronger expression under winter conditions. Direct absorption by the tissues of odors from some varieties of food eaten is well known in man. The possibilities in fishes, such as carp, which, if they do not actually take up by choice appreciable quantities of foulsmelling sludge, do at times feed heavily upon snmall bottom organisms that have done so, need only to be mentioned to be realized. In the fouler areas ranged over by carp, not only the small oligochaetes, which swallow mud or sludge in large quantitics. Dut also the small bivalves, certain snails, and other bottom species tlat take bottom detritus accidentally along with the botton plankton or incrusting plant and animal growths. are likely to develop strong odors, which in turn will be reflected later on in the odor and taste of the fishes. During the summer season, of course, decompositions in the muds are likely to be nuch nearer their end points than in winter: and the exhalation of such odors through bloodstream and skin is doubtless at a relatively high rate, corresponding with the degree of activity of the fish. Another point of possible importance is the orchinary habit of the larger commercial fishes of feeding much farther away from the channel in spring and smmmer than in late fall and early winter. Fishes, on the other hand, which continue to feed a a short time after the botton is chilled, are likely to take in directly or indirectly material capable of producing especially offensive odors, as its temperature is raised to that of the body of the late feeder. And those fishes which go into winter dormancy immediately after a heavy feeding on chilled bottom will retain such odors as are absorbed nore fully and longer lecause of the lessened exhalation rate that accompanies inactivity.

Among the carp taken since 1920 at and above Peoria, also, a very high rate of disease has been observed; the percentages of affected fish to totals recently examined going above 50 at most stations. There are 
sone grounds for believing that the most prevalent of the diseases noted may be connected with the character of the food supply. As the carp is the only surviving commercial kind that is now able to maintain fair numbers in these polluted areas, comprising probably more than ninetenths recently of all fishes taken, it can be seen that a large part of the entire local fishery is affected. Dr. David H. Thompson was engaged for some time in a special study of the diseased carp in the middle Illinois River, and his report on this subject is published in this bulletin.*

\section{Changes in Abundance of the Principal Groups}

\section{During and Just After the Continuous}

\section{Summer Floods of 1924}

Of the six summer seasons, 1920 to 1925 , all except that of 1924 had the crest of the spring freshet not later than the middle of May, with gage height at Peoria dropping to between 11 and 9 feet before the end of June, and continuing within a range of 8 to 10 feet through July, August, and September. The warm season of 1924 was characterized by continuous summer floods, with the Peoria gage ranging 14 to 18 feet in June, 18 to 19 feet in July, and 19 to 20 in September. What appear to be direct effects of these very unusual flood conditions are seen in the figures of abundance of midge larvae for the season of 1924 . which almost uniformly showed decreases, some of them quite large, over the figures of the year of more normal summer rainfall preceding. The largest decreases were shown in the three reaches (Middle and Lower Peoria Lake, and foot of Peoria Lake to Pekin) where Chironomidae had been most abundant the year before. The single section, in fact, of those examined, in which average numbers of midges went above the figures of 1923 was that between Havana and Beardstown, where Chironomidae had been comparatively rare in previous collecting seasons, and into which it is possible that the flood of 1924 introduced them in somewhat more than usual numbers.

Evidence tending further to confirm our supposition that the decreases in the Chironomidae in 1924 were due to the washing away of successive broods in the egg or early larval stage, is furnished by the data of abundance of the larvae in the summer season of 1925 . Under the normal summer gages of that year large increases in midge larvae were shown in almost all reaches, with the largest increases falling mainly within the territory of largest decreases in the year preceding, if a single case of very unusual increase, in the short reach between Pekin and Copperas Creek Dam, be excepted. The latter quite possibly reflected the result of some unusual attraction furnished temporarily by the odors from the Peoria and Pekin wastes.

*Vol. XVII, Art. VIII, The "knothead" carp of the Illinois River. 


\section{TABLF X'VII}

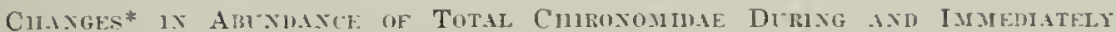
Followix; the Coxtryots Styder Floons of 1924:

Arerage Numbers per Square laro

\begin{tabular}{|c|c|c|c|c|}
\hline \multirow{2}{*}{$\begin{array}{l}\text { Reaches and } \\
\text { subdivisions }\end{array}$} & \multicolumn{2}{|c|}{1923 to 1924} & \multicolumn{2}{|c|}{1924 to 1925} \\
\hline & Channel & Extra-chaunel & Channel & Extra-channel \\
\hline $\begin{array}{l}\text { Upper Peoria Lake... } \\
\text { Mliddle Peoria Lake.. } \\
\text { Lower Peoria Lake... }\end{array}$ & $\begin{array}{r}-57 \\
-557 \\
-1,059\end{array}$ & $\begin{array}{r}-145 \\
-383 \\
-117\end{array}$ & $\begin{array}{r}-6 \\
+-60 \\
+303\end{array}$ & $\begin{array}{r}+466 \\
+629 \\
+1.261\end{array}$ \\
\hline $\begin{array}{l}\text { Foot of Peoria Lake ro } \\
\text { Pekin …......... } \\
\text { Pekin to Copperas }\end{array}$ & -400 & $-5 i$ & +250 & +256 \\
\hline $\begin{array}{l}\text { Pekm to Copperas } \\
\text { Creek Dam ........ }\end{array}$ & -104 & -11 & +54 & $+10,49=$ \\
\hline $\begin{array}{l}\text { Copperas Creek Dam } \\
\text { to Liverpool......... } \\
\text { Liverpool to Havana.. }\end{array}$ & $\begin{array}{l}-62 \\
-36\end{array}$ & $\begin{array}{c}\text { no collect- } \\
\text { ions } 1923 \\
-23\end{array}$ & $\begin{array}{l}\text { no collect- } \\
\text { ions } 1925 \\
\text { no change }\end{array}$ & $\begin{array}{c}\text { no collect- } \\
\text { ions } 1925 \\
-26\end{array}$ \\
\hline Havana to Beardstown. & +4 & +22 & +8 & +139 \\
\hline
\end{tabular}

Examination of the figures of abundance for the other two leading groups among the small bottom animals, the Splacridac and the Tubificidac, fails entirely to disclose similar trends in those gronps in the periods $1923-1924$ and $19 \cdot 2+1925$. Quite to the contrary. in $19 \%-4$. while midge larvae were sharply declining. both. Musculium transiersum (which made up) more than !n jer cent of the Sharriidas in most reaches) and total Tubificidac were showing tair to heary increases in numbers. or declines that (relatively to the largest increases) were unimportant. Again. while Chironomidac in 192. were rising sharply in almost all reaches, far the largest changes in the Sphacridac were downward, and several of the largent changes in the Tubificidar, itenizing by reaches and areas. were in the same direction.

While the effects of a variety of tactors, impossible wholly to separate from eacl other, may be concerned here. the must reasonable explanation of the principal changes in abundance of these two gromps (Sphacridac and Tubificidac) between 1923 and 19.21 seems to be to regard them as largely indirect effects of the wide shift in water levels during the period. At least it is clear that similar effects easily conld be obtained through the medium of lessened. iollowed by increased. foraging in the deeper open waters by the bottom-ranging fishes: the amount of feeding. in its turn. being infuenced by gage heights. It is well known that. throughont the spring and summer season as there arises opportunity. the fish depart to a great extent from the deeper water to feed in the "brush" -or in other words. territory into which our collecting has not taken us since the close 
of field operations in the region of Havana before 1920 . It is evident that changes in abundance of the small bottom animals, provided they are of kinds not so easily washed away as the majority of the comnoner Chironomidac of the Illinois River seem to be, would be in some measure during a growing season of continuous flood in proportion to the extent of this migration.

Evidence confirmatory to some extent of this view of the case seems to be furnished in the fact that the Splacriidac showed the largest increases during the flood of June to September, 1924, in Upper Peoria Lake and from Liverpool to Havana, where, in each case, that group harl been most abundant the year before, and where, in the case of the first area mentioned, there is a very large acreage of "brush" territory contiguous to the area represented by our collecting stations. Likewise, the large decreases in the Sphacriidac between $192 t$ and 1925, along with the presumable re-entrance of the fishes into the deeper and more open waters for spring and summer feeding, also took place in the sanne two sections of river (i. e., Upper Peoria Lake and Liverpool to Havana), where the greatest increases had occurred the year before. This finding is, in its turn, at least consistent with the popularly held supposition that large fishes which move about considerably are alert to discover and ntilize the riclsest feeding grounds, provided of course, that the axygen supply is adequate. In order for the latter to have been the case in Upper Peoria Lake in 1925. it seems necessary to assume that the bulk of the cutting down of the surplus stores of Sphacriidac laid up there in 1924 was done from April to June rather than in July and August.

\section{TABLE XVIII}

Cinanges* in Abundange of Musculium Transversum DuRixg axb ImMedAtely Followixg the Coxtixuous SumMer Floons of 1924; Aigrage Nuabers per Square Yard

\begin{tabular}{|c|c|c|c|c|}
\hline \multirow{2}{*}{$\begin{array}{l}\text { Reaches and } \\
\text { subdivisions }\end{array}$} & \multicolumn{2}{|c|}{1923 to 1924} & \multicolumn{2}{|c|}{1924 to 1925} \\
\hline & Channel & Extra-channel & Channel & Extra-channel \\
\hline $\begin{array}{l}\text { Upper Peoria Lake... } \\
\text { Middle Peoria Lake.. } \\
\text { Lower Peoria Lake... }\end{array}$ & $\begin{array}{r}+16,977 \\
+1.844 \\
+130\end{array}$ & $\begin{array}{r}+14,533 \\
+1,044 \\
+49\end{array}$ & $\begin{array}{r}-15,242 \\
+3,164 \\
+1,238\end{array}$ & $\begin{array}{r}-14,828 \\
+1,596 \\
+327\end{array}$ \\
\hline $\begin{array}{c}\text { Foot of Peoria Lake } \\
\text { to Pekin .......... }\end{array}$ & +40 & +132 & $+1,064$ & +36 \\
\hline $\begin{array}{l}\text { Pekin to Copperas } \\
\text { Creek Dam ........ }\end{array}$ & $-\$ 2$ & +124 & +34 & +38 \\
\hline $\begin{array}{l}\text { Copperas Creek Dam } \\
\text { to Liverpool......... } \\
\text { Liverpool to Havana. } \\
\text { Havana to Beardstown }\end{array}$ & $\begin{array}{r}-26 \\
+17,928 \\
-199\end{array}$ & $\begin{array}{l}\text { no collect- } \\
\text { ions } 1923 \\
+7,200 \\
+40\end{array}$ & $\begin{array}{l}\text { no collect- } \\
\text { ions } 1925 \\
-5,424 \\
+5,290\end{array}$ & $\begin{array}{l}\text { no collect- } \\
\text { ions } 1925 \\
-7,058 \\
+1,843\end{array}$ \\
\hline
\end{tabular}

* Increases are represented by the $+\operatorname{sign}$, decreases by the - sign. 
Just why it was that the Sphacridac increased rather than declined in most of the other reaches. between the Middle Lake and Beardstown (except the Liverpool-to-Havana reach) in 193.5 is not wholly clear. The figures stand abont as they would. howerer. if two assumptions are granted: first, that an excessive rather than merely normal amount of feeding by the fishes is likely to occur where the botton fauna is richest, with the limitations above noted; and, second, that the normal rate of increase in the Sphacriida in recent vears, both in the areas of its greatest abundance and elsewhere, may have been in excess of normal demands from the present fish population.

Onr data on abundance of Tubificidae from 19.23 to 19:5 in the reaches between Chillicothe and Peardstown, if the single instance of Lpper Peoria Lake be excepted, reflect an irregularity that can be ascribed only to the operation or effects of several influences. In the first place, these worms increased greatly, both in the channel and extrachannel zones in Lpper Peoria Lake, during the heary floods of the summer of 19.24 . and decreased in the same part of Peoria Lake in 19:5: in both instances in quite a similar way to the changes of the Sphatriidac. In this part of Peoria Lake, the stronghold of both the Splacriidac and Tubificidac between Chillicothe and Feardstown since 1:120. and where, in fact, the worms reach vast numbers in close juxtaposition on the lake bottom with the small bivalres, it is probable that for several years the large botton-feeding fishes, when they have fed there at all, have been forced to take large ynantities of the small worms as food in order to get the Spharridac. This beings so, the explanation of the rise

\section{TAPIE NIS}

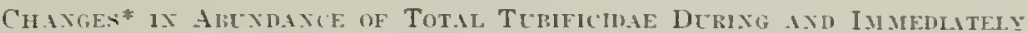
Followixg tIIE Coxtryot's StMMer Flonds of 1924:

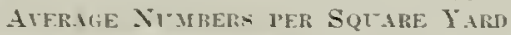

\begin{tabular}{|c|c|c|c|c|}
\hline \multirow{2}{*}{$\begin{array}{l}\text { Reaches and } \\
\text { subdivisions }\end{array}$} & \multicolumn{2}{|c|}{1923 to 1924} & \multicolumn{2}{|c|}{1924 to 1925} \\
\hline & Channel & Extra-channel & Channel & Extra-channel \\
\hline $\begin{array}{l}\text { Upper Peoria Lake... } \\
\text { Mliddle Peoria Lake.. } \\
\text { Lower Peoria Lake.. } \\
\text { Foot of Peoria Lake }\end{array}$ & $\begin{array}{r}+51,476 \\
-1,692 \\
+339\end{array}$ & $\begin{array}{r}+23.155 \\
+46 \\
+1.873\end{array}$ & $\begin{array}{r}-42.824 \\
+1,086 \\
+931\end{array}$ & $\begin{array}{r}-10.494 \\
+7 \mathrm{~S} \\
+7.6 \mathrm{~S} 2\end{array}$ \\
\hline $\begin{array}{l}\text { Foot of Peoria Lake } \\
\text { to Pekin ......... } \\
\text { Pekin to Copperas }\end{array}$ & $+3.09 \mathrm{~S}$ & $+5,75 s$ & -2.992 & $+25,245$ \\
\hline Creek Dam ...... & -164 & -352 & +160 & -220 \\
\hline $\begin{array}{l}\text { Copperas Creek Dam } \\
\text { to Liverpool........ } \\
\text { Liverpool to Havana. }\end{array}$ & $\begin{array}{r}-9 \\
-461\end{array}$ & $\begin{array}{l}\text { no collect- } \\
\text { ions } 1923 \\
+2.988\end{array}$ & $\begin{array}{l}\text { no collect- } \\
\text { ions } 1925 \\
+504\end{array}$ & $\begin{array}{l}\text { no collect. } \\
\text { ions } 1925 \\
+655\end{array}$ \\
\hline Havana to Beardstown & -27 & $+1,209$ & +4.885 & $-1,934$ \\
\hline
\end{tabular}

*Increases are replesented by the $T$ sign, decreases by the - sign. 
in numbers of the worms under the flood conditions of 1924, and the sharp decline in the much more settled summer following, is probably largely the same as that offered above for the changes in the common small bivalve, Musculimm transi'crsum.

The unusually larger increases in Tubificidac in 1925, following the flood year 192t, in several of the reaches below Upper Peoria Lake, and including even Havana to Beardstown, seem to call for a less simple explanation. In the first place, in none of the reaches of river below Upper Peoria Lake could it be said that the Tubificidac and the Sphacriidae were so crowded together on the botton in the years before 1925 that the carp and buffalo would be compelled to take them in order to get the ordinarily preferred Sphacriidac; that is, the Sphacriidac could be more readily foraged for separately in these areas than in Upper Peoria Lake, and the Tubificidac to the same extent left alone. Again, as has been mentioned in a preceding section, there are strong reasons for supposing that the unusual all-summer floods of 1924 brought down "seeding-stock" of the worms themselves, along with a rich supply of organic sediment, into several reaches of river between Peoria and Beardstown that had been poor bottom fauna and fish producers for many years before because of prevailingly hard sand-and-shell or lightly silted clay bottom.

The sharp spurt upward of the Tubificidae in the extra-channel areas of the reach between the foot of Peoria Lake and Pekin in 1925 seems most probably to have resulted from a concentration of local pollution on the east side of the river at Pekin. The richest hauls of Tubificidae, which account largely for the high average, were taken on the Pekin side, above the Corn Products Refining Company's plant, and might have originated either at Pekin or at South Peoria.

IVe may now return again to the Chironomidac to inquire what may have caused that group, previously listed with evidently good reason among the preferred foods of several of the most important of the botton-feeding fishes, to increase its numbers, either sizably or heavily in all reaches above Copperas Creek Dam in 1925, while the Splacriidac declined sharply in Upper Peoria Lake and showed relatively small or negligible increases in all the other reaches in the same distance. The answer is probably to be found partly in the fact that, in the case of the Chironomidac, we are dealing with a larger number of kinds and a much wider distribution of broods over the growing season; whereas close to 99 per cent of the Splacriidac in many sections of the river has recently been made up of Musculium transiersum, a species whose single heavy bearing season has in recent years in the Illinois River usually come as late as July or August. Even more important, perhaps, is the fact that the edible-sized larval Chironomidac periodically leave the river, actually for two weeks or niore between emergence and egg-laying, and effectively for longer periods: while the small bivalves are permanent residents on the river floor. As a consequence, largely of one 
or the other of these considerations, the large schools of carp and buffalo that made their way upstream in the early spring of 1925 could conceivably have made heavy inroads into the stocks of gravid Sphatridac at a point of especial vuluerability, antedating the normal time of heaviest birth rate by several weeks. The same schools of bottom-feeding fishes, however, could have passed up the river easily between dates of pupation and energence of sone of the earlier broods of the Chironomidac and so have lat relatively little effect on abundance of those particular kinds through the rest of the same smmmer. Or, in an unusually late spring, the same effect, in greater or less degree, conld have been produced several weels later in the season.

\section{Comparative Abundance in the Channel and Extra-channel Areas, 1920 to 1925}

Comparisons of channel and extra-channel figures of abundance of the Tubificiduc for all collecting years 1920 to 1925 shows that in all the reaches above and below Peoria lake, and in that part of P'eoria Lake which most nearly resenbbles nuwidened river in its average rate of flow (i. e., Lower Peoria Lake) they uswally reached both their highest average numbers and their maxima in the extra-channel areas. This was noted and commented 4 pon in 1922 and 1923 , and is believed to express the preference of these worms for the ordinarily more stagnant conditions prevailing in those areas and for the consequently more frequently renewed supply of rich bottom sediments, following freshets, in such situations.

In both Upper and Middle Peoria Lakes, however, quite the reverse of these conditions is found to hold: both greatest average abundance and maxima occurring in recent vears almost withont exception in the main strean-channel rather than in the wide-waters. Both of these lakes have an average low-water rate of flow both in the steam-boat channel and in the wide-waters considerably under that of the Lower Lake, and it is quite apparent that sufficient sedimentation takes place within the channel itself to supply the worms with nearly if not quite optimum soil conditions. As an additional influence on abundance of the worms in the direction noted, the fact may be mentiones that the principal part of the feeding by the large commercial fishes ordinarily takes place in the areas outside the channel; and in these two sections of Peoria Lake the close mingling of great numbers of Tubificidae and Sphacridae could easily result in the consumption of unusually large quantities of the worms by bottom fishes while in quest of the hivalves.

The large Sphacriidac, as represented by the single extremely abundant species of Peoria Lake, Musculium tronsicrsum. have not been observed to follow the rtule of the small worms, but rather, with only two or three unimportant exceptions, reached their largest average numbers per square yard in the period 1920 to 1925 in the deeper-channel areas, both in the three sections of Peoria Lalie and in the more important 
river reaches above and below it. This recent distribution of the Splucriidac as between channel and extra-channel areas quite reverses the rule that prevailed in 1913-1915, when, in the sections of river most richly supplied with those small mollusks, much the largest numbers were taken in the extra-channel areas. The rule of distribution at that time seems to have reflected, indirectly, the fact of preference for, and preemption of the channel territory by, the large Viriparidac and Pleuroccridac which have been for the most part a missing elenent in the small bottom fatna since 1920. Though the figures of abundance for total chironomid larvae over the period 1920 to 1925 are mixed and $i 1$ many cases quite indefinite as to trend, there appears a clear tendency both in all the unwidened river reaches and in Lower Peoria Lake to reach greatest numbers in the areas outside the channel-in this respect, following the rule observed of the Tubificidac. In the Upper and Middle Lakes, on the contrary, as in the instance of the worms, the highest average figures and the maxima both fell withont exception in the deeper channel areas, for reasons no doubt not substantially different from those just cited as probably affecting the Tubificidac.

\section{Changes in the Mussel Fauna of Peoria Lake, 1912 to 1925}

Danglade*, in the course of his examination of the Illinois River for the United States Bureau of Fisheries in 1911-1912, found a total of fortyone kinds of nussels in Peoria Lake (with Chillicothe, slightly above the upper end, included) but did not publish separate lists for the three subclivisions. Nineteen of these were commercial species regularly salable, of which at least ten were then easy to obtain in paying numbers. The mussels died out rapidly in all three sections of the lake during and after 191; until commercial clamming entirely ceased because of failure to obtain shells. In the stmmer of 1920 a single clammer operated a bar for a few days in the channel of the Lower Lake opposite the center of Peoria. but took nothing but dead shells except for an occasional live specimen of Amblema rariplicata or still less frequently Quadrula pustulosa. In 1920-1922 the Natural History Survey took single examples of three species (Amblema rariplicata, Anodonta imbccillis, and Quadrula pustulosa) with the Petersen bottom sampler incidentally to the collection of the small bottom fauna of the Lower Lake. Commercial clamming on a scale much reduced from that of the pre-1920 period began again in 1924 and has been continued sporadically by a few clammers since. The only commercial species obtained since then in salable quantity, however, has been the common three-ridge, Amblcma rariplicata. Following out the suggestion from the commercial clammers, the Survey in the stmmmers of 1924 and 1925 operated with a standard clammer's dip-net over fairly extensive areas between Peoria Narrows and the vicinity of Spring Bay,

* Danglade, Ernest. The Mussel Resources of the Illinois River. Report U. S. Bureau of Fisheries for 1913, Appendix VJ, pp. 1-48. 
near the foot of the Upper Lake, and took, in all, during the two seasons. 16 species. Of the sixteen kinds taken, only one, the connmon three-ridge. as in the recent commercial clamming in the Lower lake, was found in more than small and scattering numbers.

The eight species taken by us in the Upper J ake in 192t and 19:5 all came from two stations at its lower end, in both cases in unusually favorable situations: either opposite the foot of Partrilge Island, on the east side, and only shortly below the outlet of Partridge Creek; or in the unusually strong current in Spring Bay Narrows. Springs under the bed of the river are known to exist in the lower end of this section of Peoria Lake, in the vicinity of Spring Bay, their occurrence there giving the name to the old village.

At various stations in the Middle Lake, between Mossville and Towhead Island, eleven kinds were taken in 19:4-19.5. The nost of the rennant beds in the Middle Ialie were located on the west (or bluff ) side. but some successful drags were made as much as .00$)$ to $i(0)$ feet from shore on either side of the channel. Springs are very frequent along the west bluff and quite possibly exist in this section of the lake under the river and lake bed in some places. Unless this is true, or unless these species are able to bury themselves in the mund during the hot season for considerable periods (a supposition which is thought doubtful), it is hard to understand how even these musually tolerant species can have survived the destruction by pollution that occurred generally in this lake between 19) 16 and 19:0). For the recent findings, either in the Liper or Middle Lake, are not to be looked mpon as any new development, the specimens having probably remained alive in substantially their recent locations through the worst of the wave of pollution that lestroyed the more sensitive Molluscu about ten years ago.

\section{T.11:1: XX}

LXIONI).AE (1) PlokL LAkF, 1924-1925

\section{Upper Peoria Lake}

Foot of Partrilge Island Spring Bay Narrows

Fusconaia undeta. Quadrula quadrula A mblema rariplieata Lasmigona complanata Anodonta corpulenta Anodonta imberillis Lampsitis fallaciosa. Lampsilis siliquoidra

\section{Middle Peoria Lake}

Mossville to Towheal Island, miscellaneous stations

Fusconaia undata Quarlrula quadrula Amblema rariplieata Anorlonta corpulenta Anodonta suborbiculate Anolanta imbecillis obliquaria reftcan Leptodea fragilis Carunculina parva Lampsilis fallaciosa. Lampritis siliquoidea

\section{Lower Peoria Lake}

Peoria Narrows, south of bridge

F'usconvia undata Quadrula pustulosa Quarlruia yuadrula Amblema rariplicata Elliptio dilatutus Anorlonta rorpulenta Anodonta imbecillis. Obliquaria reftera Leptodea laevissima Leptodea fragilis Proptera alata Lampsilis fallaciosa. Lampsilis siliquoidea 
The thirteen kinds of mussels taken in 192t-1925 at the head of the Lower Lake, just below the Peoria Narrows wagon bridge, require no explanation, as the current is unusually swift there, and the dissolved oxygen under the worst conditions in the warm season usually ranges between $\exists$ and 5 parts per million and, when the green plankton is the most abundant and active, sometimes exceeds $\$$ parts per million.

Comparison with our own 1912 records of occurrence in the Illinois River above Chillicothe, when about 3 parts per million, instead of zero, as recently, was the usual lower limit of the dissolved oxygen at Chillicothe, shows that it is largely the same list of species now showing unusual tolerance in Upper and Middle Peoria Lake, that ranged farthest up stream in the badly fouled river above the Upper Lake (and Chillicothe) in 1912. We find, in fact, that all of the eight species found in Upper Peoria Lake in 1924-1925 ranged at least as far north as Hennepin (2\% miles above the head of Upper Peoria Lake) in 1912; that two of them (Amblcma rariplicata and Lasmigona complanata) were taken at Starved Rock (50 miles above Chillicothe) in 1912; and that two others (Anodonta corpulcnta and Quadrula quadrula) ranged then as far north as Spring Valley ( 38 miles above the head of the Upper Lake). It is also noteworthy that Amblcma rariplicala, one of the two species found as far north as Starved Rock in 1912, was the only one of the entire sixteen taken in Peoria Lake in 1924-1925 that occurred in more than very scanty numbers.

The 1924-1925 list of mussels from the Middle Lake had among its eleven species one that occurred as far north as Starved Rock in 1912 (Amblcma rariplicata); one that was taken above Peru that year; and two that then occurred as far north as Spring Valley. Of the remaining seven, four occurred as far north as Hennepin in 1912 ; one between Chillicothe and Henry; and two not at any of the 1912 collecting points.

Though the conditions of current and dissolved-oxygen supply are unusually good at Peoria Narrows, it seems also that to a great extent only the hardier mussels have been able to hold out there through and since the 191\%-1920 period of destructive pollution. So we find that the 1921-1925 list of thirteen kinds from there includes three species with a northward range between Peru and Starved Rock in 1912; three with northward range to Spring Valley in 1912; five others with occurrences as far north as Hennepin then; and the other two with older records from between Chillicothe and Henry.

Combining our 1912 lists from the river between Chillicothe and Starved Rock with the 192t-1925 lists for the three sections of Peoria Lake, we now have a total of 28 species that may be regarded as showing considerably more tolerance than the various species of middle Illinois River Unionidac not included in it. A useful subdivision of these 28 kinds on the basis of relative sensitiveness is feasible if we regard Spring Valley in 1912 as marking about the lower limit of pollutional conditions, much as those portions of the Upper Peoria Lake bed not especially protected by spring water or unusual current have done 
in more recent years. Subdividing the list in this way as best possible. and taking account of relative abundance, and the possibility of special protection afforded by spring water or current, we find that eleven of them may be classed as conditionally pollutional. with a single one of that group (Amblema rariplicata) much less sensitive than the other ten: while about 1: others may be classed as possibly early or late subpolluitional, or in other words, as more or less tolerant. In addition to the list of 28 less sensitive species immediately following. we also present here the complete list of the 41 species tisken by Danglade between Chillicothe and the ront of Peoria Lake under the decidedly cleaner-water conditions of 1912.

\section{TABLE XXI}

List of Least Sexsitne Unioxidat, Illinols River, With Fanthest Nokthward Statoos of OCCTRREXCE, 1912 AND 1924-1925

$\begin{array}{ccc}\text { Species } & \text { Farthest north } 1912 & \text { Farthest north } \\ 1924-1925\end{array}$

\begin{tabular}{|c|c|}
\hline & Amblema rariplicata.........Starved Rock.......... \\
\hline 2. & $\begin{array}{c}\text { Lasmigona complanata........Starved Rock........... Cpper Peoria Lake, } \\
\text { lower end }\end{array}$ \\
\hline 3. & Leptodea fragilis...........ahove Peru............Middle Peoria Lake \\
\hline & 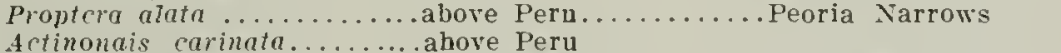 \\
\hline 6. & Quadrula pustulosa.........Spring Valley.........Peoria Narrows \\
\hline 7. & Quadrula quadrula.......... Spring Valley.......... Yper Peoria Lake \\
\hline & Anodonta corpulenta..........Spring Valley......... Tpper Peoria Lake. \\
\hline
\end{tabular}

10. Tritogonia tuberculata........ Spring Valley

11. Anorlonto grandis. var. gigantea ................. Spring Valley
12. Fusconaia undata........... Hennepiu ............ Lpper Peoria Lake.
13. Anodonta imbcrillis......... Hennepin ............ lowper Peoria Lake. lower end
14. Leptodea luevissima......... Hennepin ............Peoria Narrows

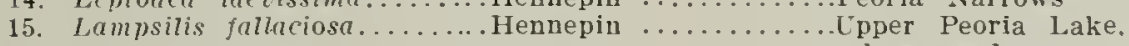
16. Lampsitis sitiquoirle ........Hennepin ........... lower end Peoria Lake, lower end

17. Strophitus cdentulus ........ Hennepin

18. Carunculina parra ........... Hennepin

19. Lampsilis rentrieosa......... Hennepin

20. Lampsilis occidens.......... Hennepin

21. Anodontoides ferrusacianus... Hennepin

22. Elliptio dilatatus............. Henry to

23. Obliquaria reflexa.............Henry to Chillicothe....Middle Peoria Lake

24. Fusconaia ebena............Henry to Chillicothe

25. Truncilla truncata...........Henry to Chillicothe

26. Plagiola lineolata.............. Heury to Chillicothe

27. Lampsilis anodontoides....... Henry to Chillicothe

28. Anodonta suborbiculata...................................... Peoria Lake 


\section{TABLE XXII}

List of Mussels Reported my Danglabe* Fron Phoria Lake, Inclusive of Cumlicotile, ix 1911-1912; Nomfaclature Revised ib Mr. F. C. Baker; ORDER OF DANGLADE'S LIST UNCIIANGED

\begin{tabular}{l|ll}
\hline 1. Cyclonais tuberculata & 21. Anodonta suborbiculata \\
2. Fusconaia ebena & 22. Anodonta imbecillis \\
3. Pleurobema plenum & 23. Strophitus rugosus \\
4. Pleurobema catillus & 24. Obliquaria reflexa \\
var. solida & 25. Tritogonia tubereulata \\
5. Pleurobema calillus & 26. Truncilla donaciformis \\
6. Pleurobcma corlatum & 27. Truncilla truncala \\
7. Fusconaia undata & 28. Plagiola lineolala \\
8. Fusconaia flava & 29. Obovaria olivaria \\
9. Quadrula pustulosa & 30. Leptodea laevissima \\
10. Quadrula fragosa & 31. Leplodea fragilis \\
11. Quadrula quadrula & 32. Proptera alata \\
12. Quadrula metanevra & 33. Caruneulina parva \\
13. Megalonaias gigantea & 34. Ligumia recta var. latissima \\
14. Amblema costata & 35. Lampsilis fallaciosus \\
15. Amblema rariplicala & 36. Lampsilis anodontoides \\
16. Elliptio crassidens & 37. Lampsilis higginsii \\
17. Elliptio dilatatus & 38. Lampsilis orbiculata \\
18. Lasmigona complanata & 39. Actinonais carinata \\
19. Arcidens canfragosus & 40. Lampsilis siliquoidea \\
20. Anodonta corpulenta & 41. Lampsilis ventricosa \\
\hline
\end{tabular}

* Danglade, Ernest, The Mussel Resources of the Illinois River. Report U. S. Bureau of Fisheries for 1913, Appendix VI, pp. 1-48.

\section{Explanation of General Tables}

As a nutter of convenience, full valuation figures in pounds per acre are given for only four of the eight collecting years beginning with 1913. In the tables of abundance and of numbers of species present and missing, much more nearly complete data for all the various years are given. The years selected for complete valuation mark all the inportant turning points in the 12 years; 1913-1915 showing substantially no change: 1922 being little different from 1920; and 1923 little different from $192 t$ and 1925 .

In the tables of abundance of leading groups of small botton animals, for similar reasons of convenience or importance, all-area averages are given only for the four years for which valuation data are presented, and only for the reaches from Upper Peoria Lake southward. Channel and extra-channel averages for the Tubificidae are given for the section of river between LaSalle and Chillicothe for the years 1923, 1924, and 1925 , only, but not for 1920 and 1922 because no quantitatively comparable collections were taken above Upper Peoria Iake until 1923. Further restriction of figures in the case of leeches and Gastropoda relates to their importance for the purposes in hand.

The lists of species on which the sumnaries of numluers of kinds taken and missing are lased liave been somewhat extended by addi- 
tional determinations in several groups, particularly leeches, since the publication of earlier papers in this series. The complete tabulations used in making np the smmmaries are in the files of the Natural History Survey, but are too voluninous and complex for present pullication in detail.

In the valuation talules the weights given in the case of Mollusca are those remaining after deduction of weight of shells, and in the case of all groups, after correction for an alscertained average body shrinkage in alcohol, in instances of the use of that preservative.

In various tables zero is used to indicate the fact of absence in reaches where collections were made: while a blank space indicates that no collections were taken.

In the valuation ancl abundance tables contractions of mixed group titles are made use of as follow's at heads of the vertical columns:

Splacriidac, for sane plus unimportant numbers of young or ¿lwarf Unionidae.

Gastropoda, for same plus unimportant numbers of Pulmonata. "Others", meaning other groups than Tubificidac. Chironomidat, Sphacridac. Leeches, ancl Gastropocla: and including (except in 19:0, when leeches were included under this head). as the most important: burrowing Ephomoridac: Hydropsy'chidae; Odonata; Tubellariu; and tmphipoda.

Bryozoa, and other incrusting or attached forms, although given places in the species lists, are excluded from the quantitative data in all cases. 


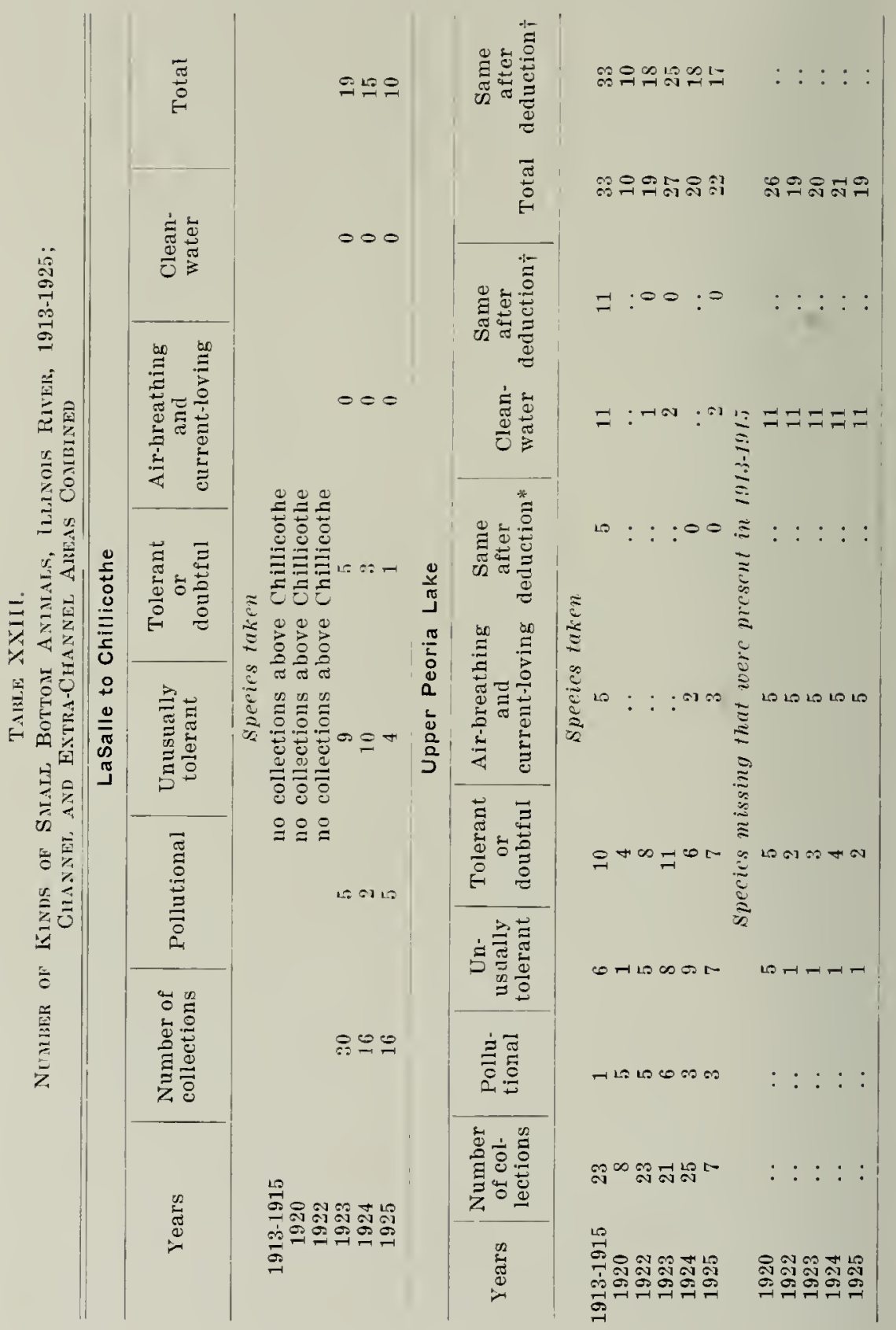



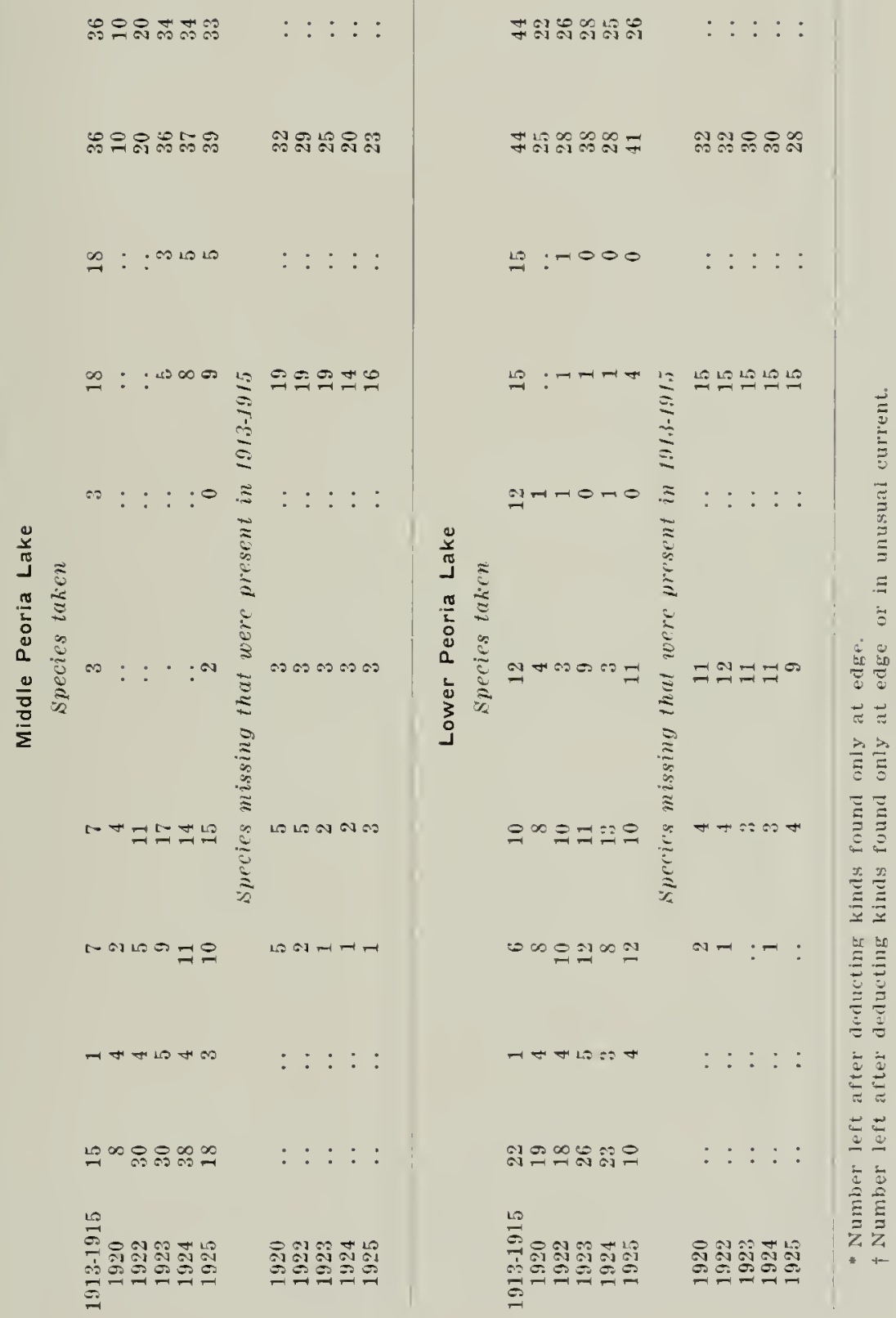


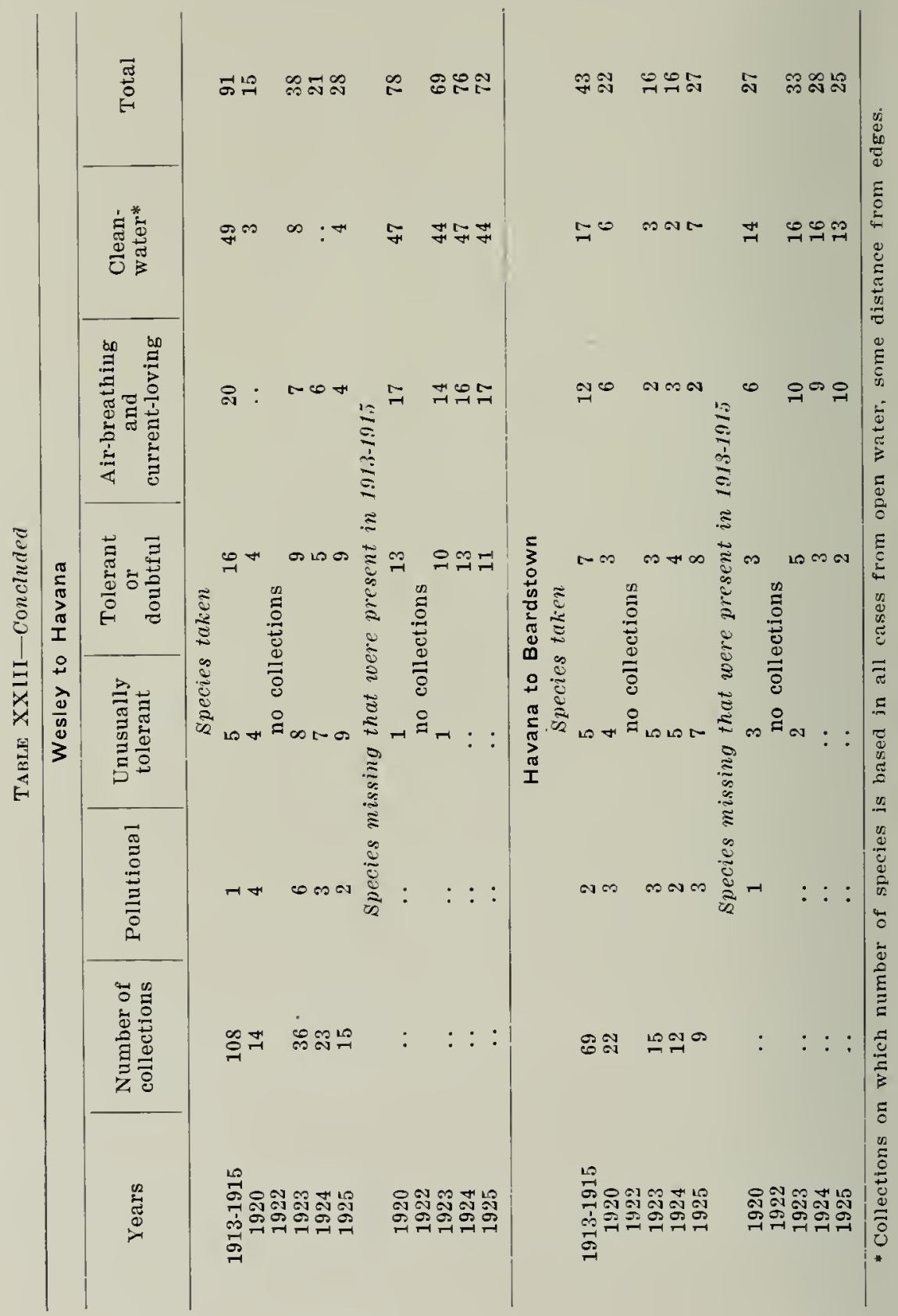


BotToM FAlNA, IlLINoIs RIVER, 1913-1925

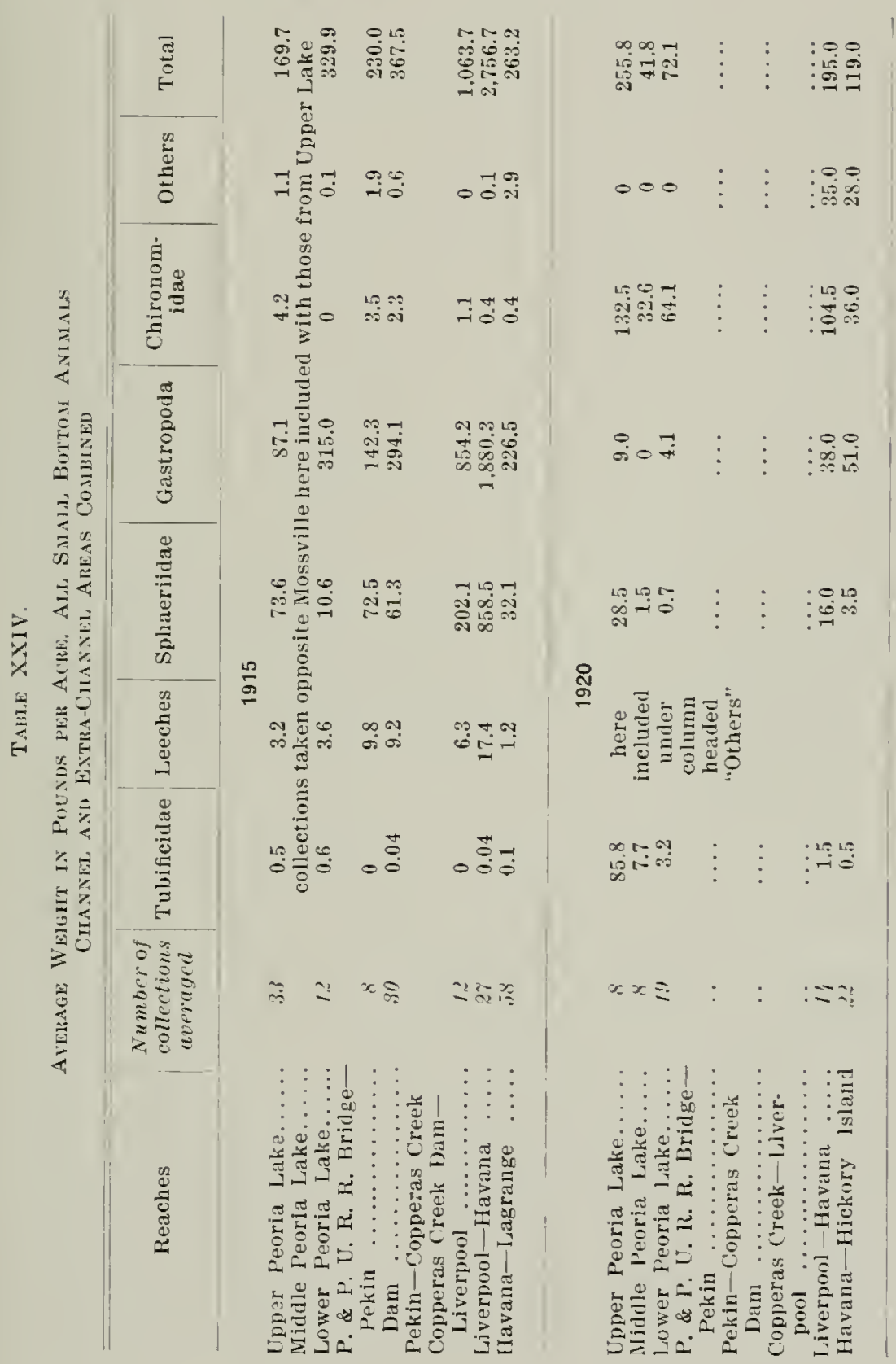




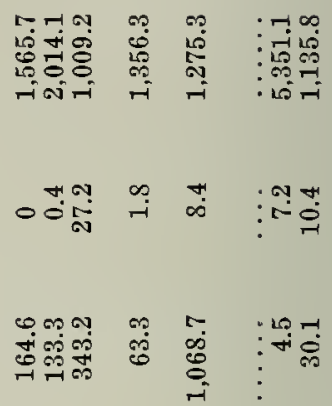

○

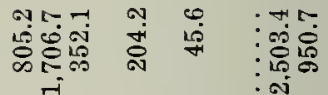
$\stackrel{\text { N }}{\text { के }}$

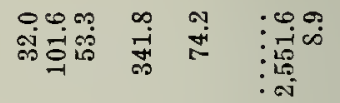

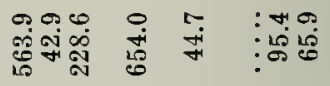

$2-\infty 0$ is $6:-0$

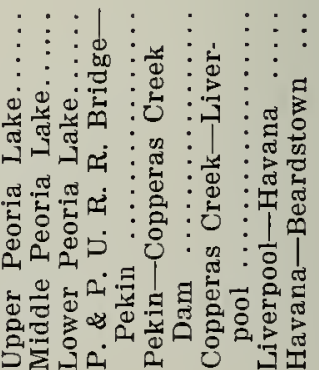


Botton FAtxi, Illixols RIVER, 1913-1925

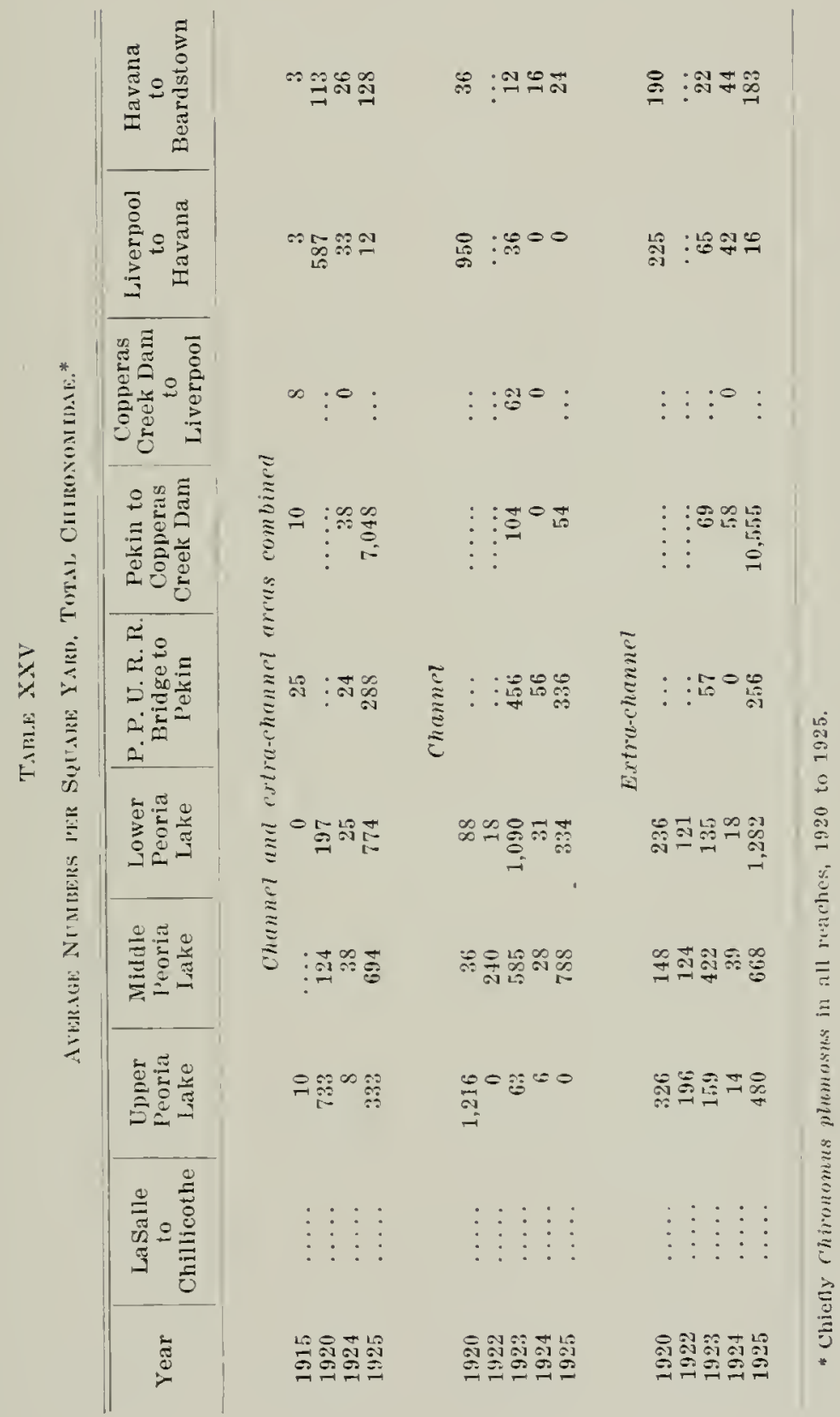




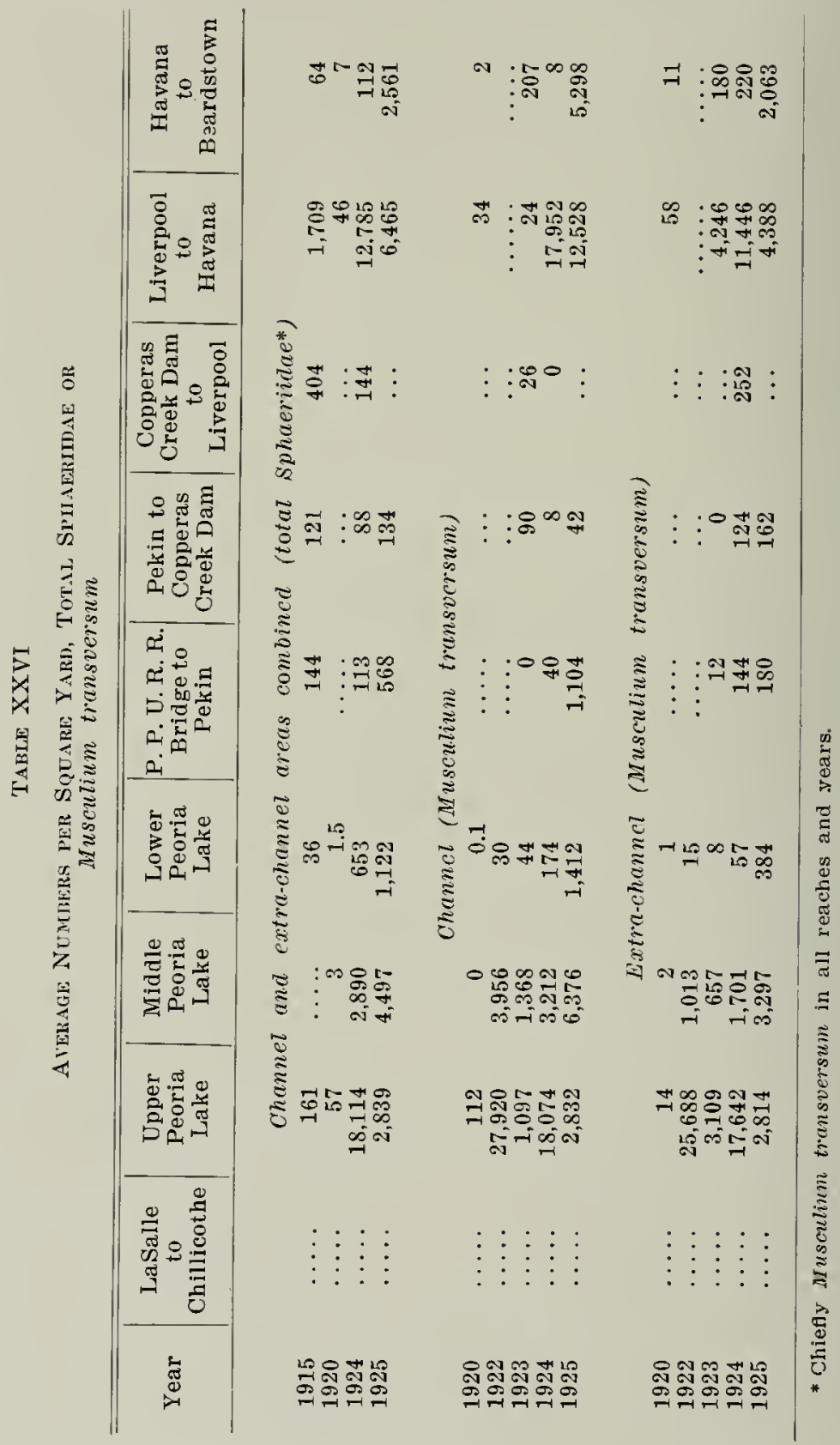


BotToM F.tx.1, IllixoIs RIVER, 1913-1925

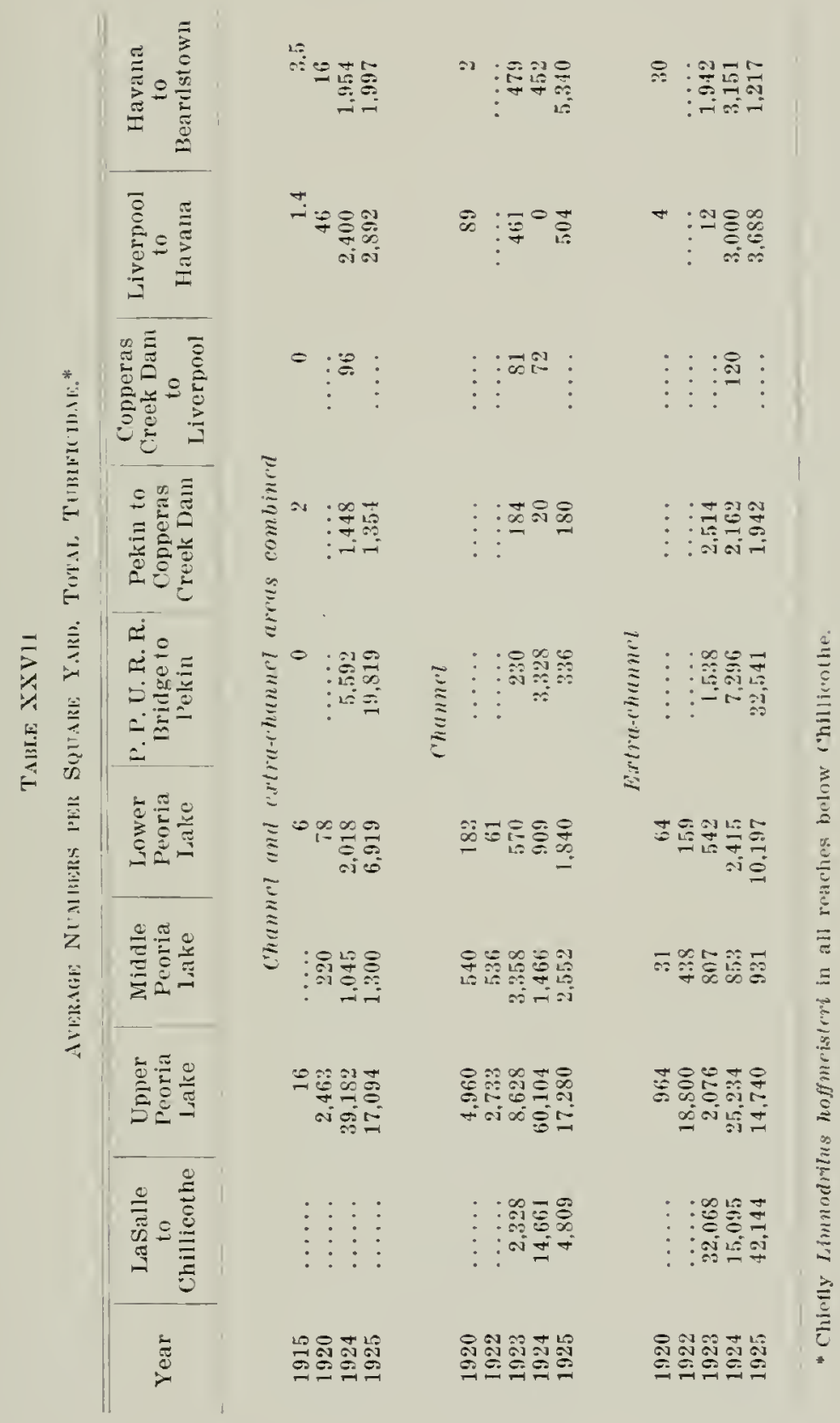



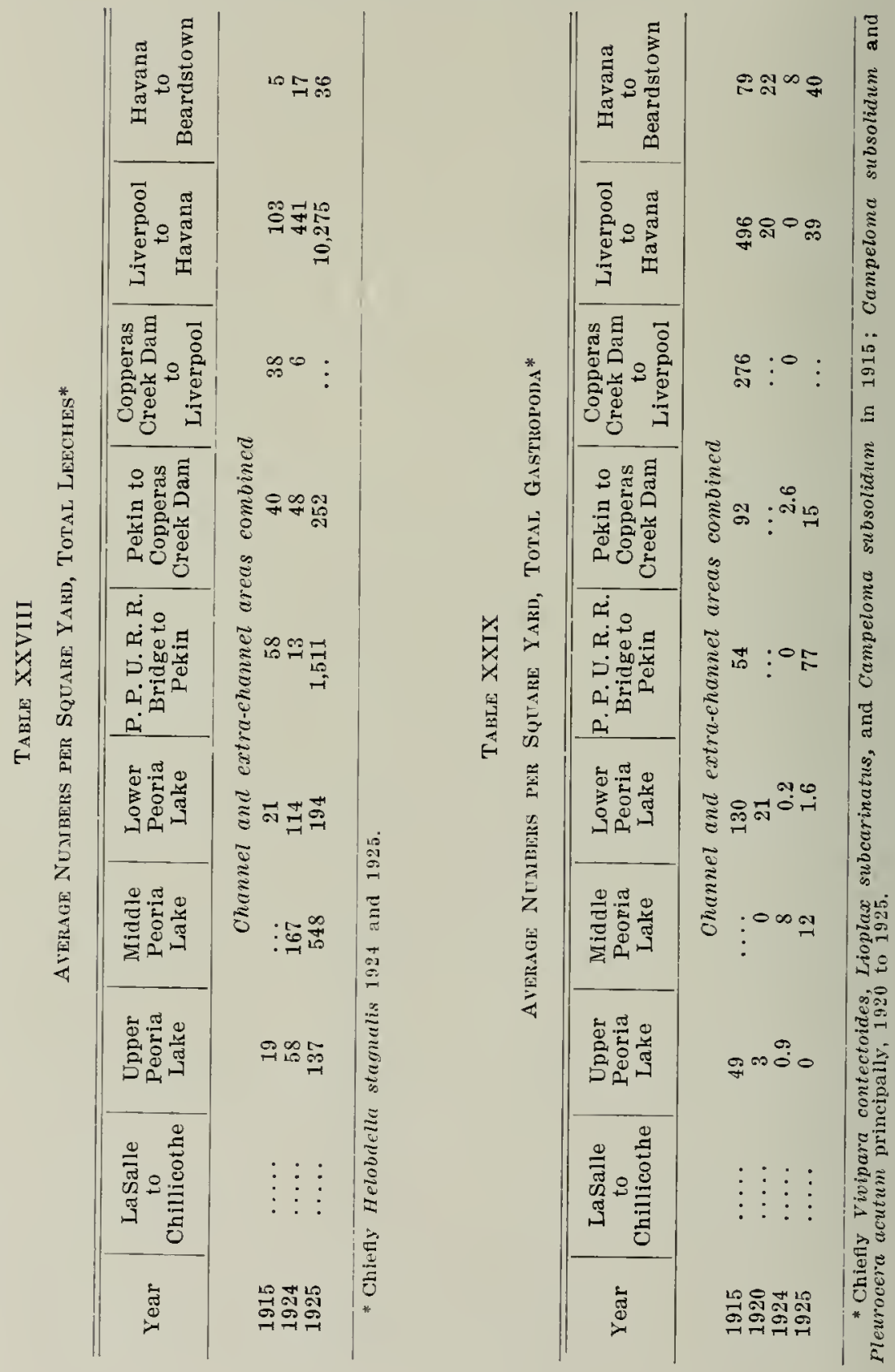


\section{Summary}

The present paper is based on a study of $1,30 \mathrm{~s}$ biological collections made by the Natural History Survey between 1913 and 1925 , inclusive. over a 295 -mile stretch of the Illinois River and in its connected bottomland lakes. For convenience in discussion, this stretch of water is dirided into eight reaches, as follows: Beginning at LaSalle, which is 101.5 miles below Lake Michigan, the first reach extends downstream to Chillicothe, a distance of 45 miles; the second, from Chillicothe to the foot of Peoria Lake, 20 miles; the third, to Copperas Creek Dam, ?t miles; the fourth, to Liverpool, 9 miles; the fifth, to Havana, 8 miles; the sixtl, to Beardstown, 31 miles: the seventh, to Lagrange Dan. 11.5 miles: and the eighth a distance of $6 . .5$ miles, to Grafton at the mouth of the river.

The upper part of the river is powerfully affected by pollution from the Sanitary District of Chicago, the effect of which diminishes slowly downstream and varies considerably with the stage of water and time of year. This pollution has increased, of course, with the population of the contributing cities and with the growth and activity of certain industries, the most important of which are those of the Chicago stockyards. During the six years from $191 \pm$ to 1990 , tangible wastes of Chicago, inchiding those of its stockyards, increased by about 11 per cent. and to these was added the sewage from minor lut increasing sources at various points down the river, especially at Peoria and l'ekin. A notalsle upward rush of pollutional ratios and effects, due to war-tine activities of the stockyards, culminated in 1 !n 1 in a sewage contribution from this source equivalent to that of a popmlation of 1.390 .000 people, but fell off during the first two years of peace by about 2.; per cent.

An effort is made to distinguish septic, pollutional, sulp-pollutional. and clean-water conditions by the plant and aninal species eharacteristic of each, and from these to select an index series of speeies whose ahmmdance marks the grade of pollution in which each species predominates: but this classification of degrees of pollution is difficult becanse the several divisions fade into each other gradually with no well-marked boundaries. and different grades intermingle in the same locality, those of the main current of the stream differing from those dominating in comparatively sluggish, shallow, and weedy marginal waters; and these differing again from those of still more sluggish, broad expanses of shallow water. Even in the ehannel of the river itself the organisns suspended in the flowing strean differ, often widely, both in relative abundance and in sensitivity, from those of the hotton sediments, and the conclusion is reached that a dependable classification can be arrived at only by the supplementing of chemical data with a comprehensive study of the dominant famma and flora in each situation.

Increase of pollution between 1913 and 1920 is shown by the advance downstream of stages of pollution. Clean-water conditions, which in 1913 extended upstream within 33 miles of 1 asalle, had receded by $19: 20$ to a point 53 miles still farther down, an average recession of about 8 miles a year. 
Deterioration of the condition of the river bottom during this interval is shown also by a reduction in the number of species represented in the bottom famna, amounting to an average of 64 per cent in the Peoria Lakes, 83 per cent in the river between these lakes and Havana, and 48 per cent between Havana and Beardstown.

Another measure of increased pollution is found in the number of characteristically clean-water species that disappeared during the same interval. The Peoria Lakes, for example, were entirely cleared of these species by 1920. In the 19 miles next below they had been reduced from 49 species to three, and in the next 31 miles from $1 \%$ species to six. Corresponding data are given for an increase in the number of pollutional and sub-pollutional species during the same interval and over the same sections of the river, but there was some slight recovery of clean-water species after the end of the world war. The dissolved oxygen data constitute a similar record of rapid decline from 1912 to 1920 and of a partial recovery in the Peoria Lakes by 1925.

The effect of increasing pollution upon the more important groups of the bottom fauna is reflected in a general and often very large decrease in average numbers per square yard in all of these groups except the pollutional sludge worms (Tubificidae) and midge larvae (Chironomus), which multiplied enormonsly in this period. In a 10-mile section of the river just above Havana, for example, where there were 1.,09 Sphaeriidae (small bivalve mollusks) per square yard in 1915, there were only 46 per square yard in 1920 and the numbers of Gastropoda (snails) declined from 496 to 20 ; but where there were 16 sludge worms and 10 midge larvae per square yard in 1915 there were 2.463 sludge worms and 733 midge larvae in 1920, and in the following four or five years the numbers of sludge worms had still further multiplied to 39,182 per square yard. From 1920 to 1925 , however, the Sphaeriidae, which had been diminishing so rapidly nnder the heavier pollution of the war period, recovered quickly as pollution diminished, rising in the 10 -mile section just mentioned from 46 per square yard in 1920 to 12,885 in 1924 . This uprising of Sphaeriidae appears to have been checked and reversed by an epidemic outbreak of predaceous leeches preying on them, the leeches themselves multiplying from 441 to 10,275 per square yard, while the Sphaeriidae fell from 12,785 to 6,465 .

Valued by total woights instead of numbers of organisms, the small botton fauna (mostly gastropod mollusks) ranged in 1915 from 170 to 360 pounds per acre between Chillicothe and the Lagrange Dam except in a 1i-mile section above Havana where it rose to 1,000 pounds per acre in the upper 8 miles and 2,700 pounds in the lower 9 miles; but by 1920 these snails were virtually exterminated in the Peoria Lakes, where, on the other hand, the sludge worms and midge larvae of a polluted water rose to 86 per cent of the total weight. Between Liverpool and Havana gastropod mollusks were reduced to 19 per cent of the average haul, and midge larvae were increased to 53 per cent. 
Following upon prolonged and destructive floods in the summer of 19:4. which presumably carried down and distributed great quantities of up-the-river sludge and its inhabitants, there was an enormous increase of the total product made up mostly of sludge worms. midge larvae. and Musculium transicrsum (a little bivalve mollusk unusually tolerant of pollutional conditions). In the three Peoria Lakes and in the Liverpoolto-Havana section of the river, the total weight rose in $19 ?+2$ to ?.) or 26 times that of 1920 , composed in the lakes almost wholly of the little Nusculium, which made 80 per cent to 94 per cent of the product of an average haul.

Study of the competitions and depredations of the more important groups of the bottom animals shows that under clean-water conditions snails, by their feeding methods, tend to dominate and. where they become abundant, to stuppress midges, sludge worms, and the smaller Sphaeriidae, and that sucker-mouth fishes draw heavily upon small mollusks and larvae of midges, marflies, and caddis flies, preferring these to sludge worms, leeches, and the larger snails. Only cattishes (and sheepsheads) prey extensively upon the larger snails. "The destruction of the latter by pollution and the release by this means of the small Sphaeriidae affords to "coarse fish" an increased available food supply" and so may be a benefit rather than a detriment to commercial fisheries. On the other hand, the frequently gassy taste and, in the case of the carp, the diseased condition of as many as in per cent, che to the effects of pollution upon their food, climinishes the market value of lllinois River fishes.

The numbers of midge larvae and of Musculium were at first diminished and afterwards increased by the floods of 1424 , and the numbers of sludge worms were at first increased and afterwards diminished. These contrasting variations and those of Musculimm, as a consenuence of the floods, are described and discussed in detail with suggested explanations; and a study is reported of the comparative abundance of these same groups in the river channel and in the shallow waters adjoining. The effect of pollutional conditions on the river mussels is shown by a comparison of a list of $t 1$ species found in Peoria Lake in 1911 and 191? with the 15 species renaining in $199+2$ and 1935 . eight of then in the upper lake, eleven in the middle, and thirteen in the lower.

The lag of the small bottom animals behind the dissolved oxygen (and also the plankton and bacteria of the epilimnion) appears to be due principally to two causes-the naturally slow rate of re-spread npstream of cleaner-water forms, as against the easier downstream movement of the pollutional and unusually tolerant bottom species: and the delivery, with every flood, into territory that would otherwise remain reasonably clean, of fresh loads of incompletely oxidized organic sediment.

From the preceding statement, and others in the body of this paper. the inference is drawn that the small bottom animals, except where the pollution is very heary, on the whole furnish a better index of the funda- 
mental or permanent sanitary condition than the frequently rapidly changing dissolved oxygen or plankton.

Bearing in mind the popular distinction between "coarse" fishes and "fine" fishes, which may usefully be extended for the moment to the small bottom animals, it is to be emphasized that the increases in pounds-peracre averages between Chillicothe and Beardstown since 1920 represent alnost wholly enlargement in quantity at the expense of quality, and have occurred for the most part without corresponding permanent improvement in sanitary condition. Such food is available only to the fishes which are able to live under the conditions prevailing where it is produced; and large portions of those areas are still subject in the warm season to spells of oxygen depletion that are likely to exclude from these rich feeding grounds all except the most tolerant of the bottom feeding fishes. 


\section{APPENDIX TO ARTICLE XII}

The following is a list of publications of the State Natural History Survey and its predecessor, the State Laboratory of Natural History, dealing in whole or in part with investigations of the Jllinois River. The asterisk marks articles relating to Illinois River biology as such, to distinguish them from others of a more general nature which contain some information on this subject.

\section{Bulletin Series}

1876. List of Illinois Crustacea. S. A. Forbes. Vol. I, No. 1, pt. 1. (25 pp., 1 pl.)

1876. A partial catalogue of the fishes of lllinois. E. W. Necsox. Vol. I, No. 1, pt. $4 . \quad(30$ pp.)

1877. A catalogue of the fishes of Illinois. DAvill STAR Jords. Vol. I, No. 2, pt. 4 . (34 pp.)

1877. The food of Illinois fishes. S. A. Fonbls. Vol. I, No. 2, pt. 5. (19 pp.)

1880. The food of fishes. S. A. Forises. Vol. 1, No. 3, pt. 2. (4S pp.)

1880. On the food of young fishes. S. A. Fonbes, Vol. I, No, 3, pt. 3. (14 pp.). Second cdition. 1911.3. Reprint, 191\%.

1883. The food of the smaller fresh-water fishes. S. A. Forbes. Vol. I, No. 6, pt. 3. (30 pp.)

18ss. Studies of the food of fresh-water fishes. S. A. Fokses. Vol. II, Art. 7. (41 pp.)

18ss. On the food relations of fresh-water fisles: a summary and discussion. S. A. Fonbes. Vol. II, Art. 8. (63 pp.)

*1895. On the elltomology of the Illinois River and adjacent waters. C. A. HairT. Vol. IV, Art. 6. (125 pp., 12 pl.)

*1896. Descriptions of new species of Rotifera and Protozoa from the Illinois River and adjacent waters. Anorll HEMPE., Vol. IV, Art. 10. (8 pp., 5 pl.)

1897. Contribution to a knowledge of the Nortli American fresli-water Ostracoda included in the families Cytheridae and Cyprididae. Richard W. Sirarpe. Vol. IV, Art. $15 . \quad(71$ pp., 10 pl.)

*1597. Plankton studies. 1. Methods and apparatus in use in plankton investigations at the Biological Experiment Station of the University of Illinois. C. A. liofon. Vol. V, Art. 1. (25 pp. 7 pl.)

1897. A contribution to a knowledge of the North American fresh-water Cyclopidae. Ennest B. Forbes. Vol. V, Art. 2. (56 pp., 13 pl.)

1897. The Nortl American species of Diaptomus. F. W. Scuncrit. Vol. V, Art. 3. (111 pp., $15 \mathrm{pl}$.)

*1898. Plankton studies. II. On Pleodorina illinoiscnsis, a new species from the plankton of the llinois River. C. A. Koforn. Vol. V, Art. 5. ( $21 \mathrm{pp}, 2$ pl.)

*1899. A list of the Protozoa and Rotifera found in the Illinois River and adjacent lakes at Havana, Hlinois. AnoL'll Hewlel. Vol. V, Art. 6. ( $\$ S$ pp.)

*1899. A statistical study of the parasites of the Unionidae. H. N. KEILY. Vol. V, Art. S. (20 pp.) 
*1899. Plankton studies. IJI. On Platydorina, a new genus of the family Volvocidae, from the plankton of the lllinois River. C. A. Kofow. Vol. V, Art. 9 . (22 pṇ., 1 pl.)

1901. The Hirudinea of Illinois. J. Percy Moore. Vol. V, Art. 12 ( 69 pp., 6 pl.)

*1903. Plankton studies. IV. The plankton of the Jllinois River, 18941899 , with introductory notes on the lydrography of the Illinois River aud its basin. Part J. Quantitative investigations and general results. C. A. KoFoln. Vol. VI, Art. 2. (535 pp., 50 pl.)

1904. A review of the sunfishes of the current genera Apomotis, Lepomis, and Eupomotis, with particular reference to the species found in Illinois. R. E. Richarissox. Vol. VII, Art. $3 . \quad(9$ pp.)

1906. A catalogue of the Mollusca of lllinois. F. C. BAKER Vol. VII, Art. 6. (84 pp., I map.)

1907. On the local distribution of certain Illinois fishes: an essay in statistical ecology. S. A. Forises. Vol. VII, Art. 8. (31 pp., 15 maps, 9 pl.)

*1908. The plankton of the Illinois River, 1894-1899, with introductory notes upon the hydrography of the Illinois River and its basin. Part Il. Constituent organisms and their seasonal distribution. C. A. Kofold. Vol. VIJI, Art. 1. (360 pp., 5 pl.)

*1913. Observations on the breeding of the European carp in the vicinity of Havana, Illinois. R. E. RichabDsos. Vol. IX, Art. 7. (19 pp., I map.)

*1913. Observations on the breeding habits of fisles at Havana, lllinois, 1910 and 1911. R. E. Richandsox. Vol. IX, Art. 8. (13 pp., 1 pl.)

*1913. Studies on the biology of the upper Illinois River. S. A. ForbEs and R. E. Rioharusox. Vol. IX, Art. 10. (95 pp., 21 pl.)

*1915. The Chironomidae, or midges, of Illinois, with particular reference to the species occurring in the Illinois River. JoHN R. Malloch. Vol. X, Art. 6 . (269 pp., 24 pl.)

1918. Ways and means of measuring the dangers of pollution to fisheries. Victor E. SHetFord. Vol. XIII, Art. 2. (18 pp.)

*1919. Some recent changes in Illinois River biology. S. A. FonBEs and R. E. Richarnsox. Vol. XIII, Art. 6 . (18 pp.)

*1919. Acanthocephala from the Illinois River, with descriptions of species and a synopsis of the family Neoechinorhynchidae. H. J. VAN CLEAVE. Vol. XIIJ, Art. $8 . \quad(33$ pp., 7 pl.)

*1921. The small bottom and shore fauna of the middle and lower Illinois River and its connecting lakes, Chillicothe to Grafton: its valuation; its sources of food supply; and its relation to the fishery. R. E. Ricilakdsox. Vol. XIII, Art. 15. (161 pp.)

*1921. Changes in the bottom and shore fauna of the middle Illinois River and its connecting lakes since $1913-1915$ as a result of the increase, southward, of sewage pollution. R. E. Richardson. Vol. XIV, Art. 4. (43 pp.)

1923. The determination of lydrogen-ion concentration in connection with fresll-water biological studies. Victor E. Shelford. Vol, XIV, Art. 9. (17 pp.)

*1925. Changes in the small bottom fauna of Peoria Lake, 1920 to 1922. R. E. Ricilaroson. Vol. XV, Art. 5 . (61 pp.) 
*1925. Illinois River botton fauna in 1923. R. E. Rrchardsox. Vol. IV, Art. 6. (31 pp.)

*1925. Some observations on the oxygen requirements of fisbes in the Illinois River. D.tip H. Tronlsox. Vol. XV, Art. 7 . (15 pp.)

1928. The biological survey of a river system-its objects, methods, and results. S. A. Folises. Tol. XVI1, Art. 7 . (s pp.)

*1938. The "knothead" carp of the Illinois River. D.ru H. Thompsox. Vol. XVII, Art. S. (36 pp.)

*1928. The botton fauna of the middle Illinois River, 1913-1925: its distribution, abundance, valuation, and index value in the study of stream pollution. R. E. Rlilukniox, ToI. XVII, Art. 12. ( 86 pp.)

\section{Reports of the Director of the Illinois State Laboratory of Natural History \\ S. A. Forbes, Director}

1SSS. Report for 1SS7-1SSS, pp. 2-4: General program of aquatic zoology:

1894. Report for 1893-1894, pp. 3-26: Zoological exhibit at the Columbian Exposition, establishment of the Illinois River biological station at Havana, etc. $(15 \mathrm{pl})$

*1596. Report for 1S95-1596, pp. 7-31: Special report of the biological experiment station. ( $20 \mathrm{pl}$.)

*1S9S. Report for 1\$97-1S9S, pp. 4-7: l'ersonuel, equipment, summer school, etc.; also pp. 5-25: Report of the superintendent of the biological station, C. A. Korow; fp. 25-27: Report on water analysis, by AkTHTR W. PAlater, professor of chemistry: and pp. 29-31: Report on the summer school of 1S95, by Frixk Surnu, assistant proftssor of zo. ology. $(10 \mathrm{pl}$.

1901. Report for 1599-1900, pp. 3-11: Stuly of lllinois fishes and care of collections; study of the plankton, aquatic insects, and leeches; expansion of the library and its exchange list; etc.

1915. Report for 1913-1914, pp. 7-10: Continuation of operations on the Illinois River and its tributary waters.

\section{Final Reports on the Natural History Survey of Illinois}

1908. The fishes of lllinois. S. A. Forms and R. E. Richispsos. Fol. III of the final reports on the natural history survey of Illinois. (cxxixvi+35i pp.. 65 pl.. 76 text fig.; 103 maps in a separate atlas.) second calion. 1!?"11. 